\title{
Resistências religiosas afro-brasileiras e indígenas contra a intolerância e o racismo no Brasil
}

\author{
O livro de literatura infantil no combate ao racismo e a intolerância \\ religiosa
}

The book of children's literature in combating racism and religious intolerance

\author{
Monica Abud Perez de Cerqueira Luz ${ }^{1}$ \\ mapcluz@,hotmal.com.br
}

\begin{abstract}
Resumo: O presente trabalho tem como principal objetivo analisar os discursos veiculados em livros de literatura infantil a partir de uma perspectiva pós-estruturalista e de alguns apontamentos sobre a articulação entre o discurso, o poder e o conhecimento. Utilizaremos para análise os livros de literatura infantil produzidos após a promulgação da Lei n. ${ }^{\circ}$ 10.639/2003, que estabeleceu a inclusão no currículo oficial da rede de ensino a obrigatoriedade da temática "História e Cultura Afro-Brasileira", buscando compreender como os discursos e as formas textuais e iconográficas podem ou não trazer uma carga intencional, estereotipada, naturalizada e constituída do que é ser negro. A nossa hipótese inicial é a de que, os discursos sobre os personagens negros e negras, bem como de sua cultura, ancestralidade e religiosidade mantêm a operacionalização do racismo na literatura infantil. Do ponto de vista teórico-metodológico, a pesquisa é qualitativa, de cunho etnográfico.
\end{abstract}

Palavras-chave: Literatura infantil. Racismo. Intolerância religiosa. Relações raciais.

Abstract: The present work has as main objective to analyze the discourses presented in books of children's literature from a post-structuralist perspective and some notes on the articulation between discourse, power and knowledge. We will use for analysis the books of children's literature produced after the promulgation of Law No. 10,639 / 2003, which established the inclusion in the official curriculum of the teaching network of the subject matter "History and Afro-Brazilian Culture", seeking to understand how discourses and the textual and iconographic forms may or may not bring an intentional, stereotyped, naturalized and constituted charge of what it is to be black. Our initial hypothesis is that discourses on black and black characters, as well as their culture, ancestry, and religiosity, keep the operationalization of racism in children's literature. From the theoretical-methodological point of view, the research is qualitative, of an ethnographic nature.

Keywords: Children's literature. Racism. Religious intolerance. Race relations.

\footnotetext{
${ }^{1}$ Pedagoga, Psicopedagoga, Mestre em Psicologia da Educação e Doutora em Educação.
} 


\section{Introdução}

A definição do tema desta pesquisa origina-se exatamente pela invisibilidade dos personagens negros, de sua cultura, religiosidade e ancestralidade nas histórias infantis. É um grande engodo ao dar como sinônimo os conceitos de diferença e diversidade produzindo um discurso homogeneizado sobre a identidade, desconsiderando as particularidades dos sujeitos, suas histórias e culturas.

Um país constituído por um povo mestiço, onde o racismo e suas práticas excludentes perpetuam sorrateiramente desde a abolição da escravatura em 13 de maio de 1888 até os dias atuais. O mito da democracia racial $^{2}$ sustenta uma pseudo-harmonia entre brancos e não brancos que não existe. Ele surge como um legado da escravidão que levou a um desenraizamento do povo negro de suas marcas históricas.

Nos anos de 1950, Florestan Fernandes ${ }^{3}$, Roger Bastide, Oracy Nogueira, Thales de Azevedo, dentre outros pesquisadores, iniciaram uma série de estudos patrocinados pela UNESCO, que culminaram na modificação substancial da interpretação acerca das relações raciais no contexto da sociedade brasileira.

De uma sociedade até então tida como racialmente resolvida, com uma democracia étnico-racial, como acreditava Gilberto Freyre (2000), Florestan Fernandes (1965) constatou que os grupos raciais se posicionam de modo diferente no interior da ordem social e que a distribuição das posições sociais está intimamente relacionada ao preconceito (pré-disposição para a ação) e à discriminação racial (ação) praticada contra os negros. Assim, quando as possibilidades abertas pela sociedade capitalista, com seus mecanismos de competição, permitem a ascensão social de negros, o preconceito de raça e de classe se manifesta.

Para Munanga (2015) existe um racismo estruturante na sociedade brasileira, que submete as identidades múltiplas que constituem a população. Assim, alerta para a necessidade de buscar o passado desse povo negro: o resgate da identidade afro-brasileira com

\footnotetext{
O Mito da democracia racial é a ideia de que haveria no Brasil, ao contrário de outros países como África do Sul e Estados Unidos, uma convivência pacífica entre as etnias, além do que todos teriam individualmente chances iguais de sucesso. Conceito derivado da obra de Gilberto Freyre, sociólogo brasileiro dos anos de 1930, responsabilizado pela criação deste "mito" embora não tenha dito ou escrito de forma explícita o referido conceito. Por meio de sua obra Casa-grande \& Senzala: formação da família brasileira sob o regime da economia patriarcal, teria surgido esta ideia de que no Brasil não há racismo.

3 Autor da obra $A$ integração do negro na sociedade de classes (FERNANDES, 1965), sustenta a ideia de que o racismo no Brasil existe e causa sérios prejuízos à sua população negra. A diferença é que o racismo brasileiro se manifesta como "preconceito de cor". Ou seja, a identificação entre negro ou mestiço e pobreza mascara as barreiras que mantêm a população não branca afastada das oportunidades de mobilidade social abertas pela sociedade capitalista.
} 
ênfase no processo histórico do negro no Brasil, seus valores, culturas ancestrais, religiosidade, luta e resistência.

Por meio da busca de sua identidade, o negro poderá posicionar-se em pé de igualdade com outros oprimidos não negros, travando uma luta de classes, visto que raça e classe no Brasil são duas variáveis da opressão na estrutura de uma sociedade de classes. O ideal de branqueamento $^{4}$ e o mito da democracia racial foram para Munanga (2015), na obra Rediscutindo a mestiçagem no Brasil: Identidade nacional versus identidade negra, impeditivos para a organização política, social e de consciência coletiva dos negros. A elite tentou assimilar as diversas identidades existentes no país de modo eurocêntrico, mesmo com os movimentos de resistência cultural dos povos oprimidos: indígenas e negros.

Esse trabalho pretende analisar como o personagem negro e negra, sua cultura e religiosidade estão sendo representadas na literatura infantil por meio da ótica da contrahegemonia do poder e de luta contra a exclusão social, segundo Santos (1998).

O objeto desta pesquisa é a análise e discussão das representações sociais dos personagens negros e negras, sua cultura e religião contidas nos livros infantis publicados após a promulgação da Lei n. ${ }^{\circ}$ 10.639/2003, com o intuito de compreender como o processo de construção da identidade negra acontece dentro desse contexto. Os livros analisados fazem parte de uma Biblioteca Municipal da cidade de São Paulo.

A nossa hipótese inicial é a de que atualmente ainda existe a operacionalização do racismo nas representações dos personagens negros e negras, bem como de seus costumes e religiosidade contidas nos livros de literatura infantil publicados após a Lei n. ${ }^{\circ}$ 10.639/2003.

A relevância da pesquisa está na ampliação da discussão sobre as configurações das relações sociais entre negros (as) e brancos (as) na literatura infantil, com vistas à promoção da igualdade e respeito à diversidade.

Serão utilizadas as categorias, a saber: conscientização, oprimido, identidade negra.

\section{Literatura infantil e a temática racial e religiosa}

Várias pesquisas demonstram a presença desses estereótipos negativos em relação aos negros na literatura infanto-juvenil. Um estudo de Fúlvia Rosemberg (1980) mostra os estereótipos raciais presentes na literatura infanto-juvenil produzida no Brasil entre 1950 e

\footnotetext{
4 Segundo Munanga (2015), o processo de construção da identidade brasileira deveria seguir a elite dominante, sendo, portanto, baseado no ideal do branqueamento. Tornar-se branco, para alguns negros, era escapar da discriminação racial, social, da exclusão.
} 
1975, através dos textos e das ilustrações dessas produções. A autora mostra que mulheres, crianças e não brancos encontravam-se num mesmo patamar de inferioridade face ao modelo masculino adulto branco, mesmo guardando as devidas diferenças entre mulher negra, criança não branca e homem não branco.

Com a finalidade de mudar o quadro aparente, ocorreram importantes reformas curriculares, com questões relativas ao preconceito racial. O marco é a Lei n. ${ }^{\circ}$ 10.639/2003, que impõe o ensino obrigatório da História e da cultura afro-brasileiras, incluindo o estudo da História da África e dos africanos.

A literatura infantil começou a apresentar essa temática racial em alguns livros, enfatizando o preconceito racial dissimulado e assistemático com o qual convivemos.

A literatura afro-brasileira, se utilizada de forma comprometida e com o princípio básico da desconstrução de estereótipos e preconceitos racistas, pode ser uma grande aliada no despertar da subjetividade infantil, na formação da identidade étnico-racial e na valorização da cultura negra. Pode possibilitar a construção de uma educação libertadora, como propunha Paulo Freire (1989).

Nesse contexto, a literatura infantil passa a atuar como uma das ferramentas no combate ao preconceito e à discriminação racial no Brasil, uma vez o discurso literário denuncia a atual condição do negro na sociedade e afirma um sentimento positivo de valorização da história, da identidade, dos aspectos éticos e estéticos do povo negro.

Outro traço relevante é a ênfase na importância da figura dos ancestrais, da avó e da mãe na vida das personagens, como transmissoras de uma cultura de matriz africana com o intuito de perpetuá-la (DIOUF, 2010).

Autores como Joel Rufino (1998), Abdias Nascimento (1991), Heloísa Pires Lima (2010) surgem contando a história dos negros de modo singular, sem estereótipos, dando voz à cultura africana e a religiosidade tão calada até então.

A partir de 1980, negros ligados à militância negra passam a discutir os problemas por meio das ações. Surgem grupos negros como o Ilê-Ayê e o Olodum, valorizando a cultura racial também através da música.

Uma das conquistas dos movimentos negros na educação foi a promulgação das Leis n. ${ }^{\circ} 10.639 / 2003$ e n. ${ }^{\circ} 11.645 / 2008$, que alteraram os dispositivos da Lei de Diretrizes e Bases (LDB), tornando obrigatório o ensino da temática história e cultura afro-brasileira e indígena nos estabelecimentos de ensino fundamental e médio das redes pública e privada do país, apontando, por meio das Diretrizes Curriculares para a Educação das Relações Étnico-Raciais e do Ensino de História e Cultura Afro-Brasileiras e Africanas, as ações a serem executadas 
pelos estabelecimentos de ensino de diferentes níveis e modalidades, cabendo aos mesmos orientar e promover a formação de professores e professoras, além de supervisionar o

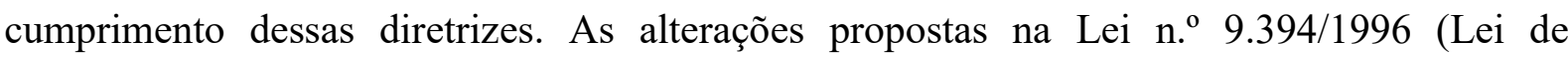
Diretrizes e Bases da Educação Nacional) pela Lei n. ${ }^{\circ}$ 10.639/2003 geraram ações do governo brasileiro para sua implementação.

O Conselho Nacional de Educação aprovou as Diretrizes Curriculares Nacionais para Educação das Relações Étnico-raciais e para o Ensino de História e Cultura Afro-brasileira e Africana por meio do Parecer CNE/CP n. 03 de 2004, estabelecendo as orientações de conteúdos a serem trabalhados em todos os níveis e modalidades de ensino.

Posteriormente, a Lei n. ${ }^{\circ} 11.645 / 2008$ veio corroborar a proposta trazida pela Lei n. ${ }^{\circ} 10.639 / 2003$, reconhecendo que os indígenas e os negros convivem com o preconceito, com a submissão e opressão.

A meta do governo desde 2003 objetivava a construção de uma escola plural, democrática, de qualidade e que pudesse combater o preconceito, o racismo e a discriminação, respeitando e valorizando as diferenças da nossa cultura, trabalhando a discussão da diversidade desde a infância.

A educação das relações étnico-raciais tem por objetivo divulgar e produzir conhecimentos, atitudes, posturas e valores que enfatizem a pluralidade étnico-racial, capacitando desde cedo as crianças a interagir, respeitar as diferenças e valorizar as identidades.

No tocante à leitura de literatura na educação infantil, após a promulgação da Lei n. ${ }^{\circ}$ 10.639/2003, a literatura se abriu para um processo de reformulação buscando distanciar-se da visão do negro como objeto ou como produto estereotipado.

Diante da promulgação da Lei n. ${ }^{\circ}$ 10.639, as escolas passaram a ensinar história e cultura afro-brasileira, incluindo temas como: história da África e dos africanos, a luta dos negros no contexto brasileiro e sua contribuição nas diversas áreas da história e da cultura do Brasil. Propõe que as crianças aprendam uma nova história: realista e respeitosa, a partir de conteúdos sobre as lutas de libertação que o negro trava até os dias atuais, em busca dos seus direitos de cidadão.

Surge a literatura afro-brasileira como resultado de reflexões, debates e principalmente das intensas lutas de movimentos negros a partir da década de 70, em diversos âmbitos sociais. Mais do que narrar histórias ficcionais de personagens negros e negras apresentam compromisso político com a difusão da cultura e da história africana. 
De acordo com Turchi (2006), a literatura afro-brasileira traz os discursos dos excluídos e esquecidos, fazendo com que a criança possa imaginar e co construir a sua subjetividade e lidar com os conflitos. Trabalhar a literatura infantil afro-brasileira contribuirá para romper com modelo eurocêntrico e monocultural, que privilegia somente os saberes da cultura européia.

Para Peixoto (2013), contemplar histórias africanas significa romper com a visão estereotipada do personagem negro e sua cultura.

Para Gomes (2005), o conceito de identidade pode ser entendido de duas maneiras distintas: singular, que se refere ao $e u$, e plural, quando aparece como recurso para a criação de um nós coletivo. E reitera:

\footnotetext{
A identidade não é algo inato. Ela se refere a um modo de ser no mundo e com os outros. É um fator importante na criação das redes de relações e de referências culturais dos grupos sociais.

Indica traços culturais que se expressam através de práticas linguísticas, festivas, rituais, comportamentos alimentares, tradições populares e referências civilizatórias que marcam a condição humana. (GOMES, 2005, p. 41).
}

Atualmente, a literatura infantil brasileira apresenta várias obras que valorizam a cultura, a identidade, a religião e os contos africanos.

Destaca-se a construção de referências estéticas e culturais voltadas para a compreensão dos significados da composição racial da população, temática que pouco ecoava nas obras endereçadas ao público infantil antes da promulgação da legislação e, raramente, quando apresentavam personagens negros e negras, estavam ligados à exclusão e submissão ao branco, relembrando o passado escravocrata.

\section{Análise das obras}

Foram analisadas 14 obras de literatura infantil disponíveis na biblioteca que abordavam mais especificamente a religiosidade e a cultura do povo africano, de acordo com as categorias: oprimido e identidade negra.

Seis dessas obras revelam o universo simbólico dos orixás e dos terreiros de Candomblé. As cores, comidas e saudações fazem parte desse repertório onde os orixás aparecem com seus cognomes, por exemplo: Omolu é o Curador, Xangô é o Trovão, Oxalá é o Criador da humanidade, Oxum é a Bela, Yansã é a Destemida. 
Outros quatro livros apontam uma relação entre ser humano e as divindades. As oferendas são referencias da crença e os castigos direcionados aos humanos e aos orixás quando desobedecem a ordem dos superiores.

Os demais livros fazem um retorno à África como origem e constituída pela figura materna dos mitos yorubás. Essas obras se referem aos rios e as aldeias. Contam sobre a criação do mundo e retratam os orixás: Oxalá, Olorum, Odudua e Exu.

De um modo geral, nesses livros muitos dos mitos e contos africanos estão presentes e dizem respeito aos orixás; as temáticas de estética e autoestima são perpassadas pela abordagem de conflitos no cotidiano das personagens e, especialmente, na construção de sua identidade. Há histórias e contos referentes às tradições afro-brasileiras que são abordadas por meio de personagens mais velhos.

Os livros analisados apresentam elementos para visibilizar o que havia sido ocultada por muito tempo na literatura infantil, dando visibilidade aos saberes ausentes e silenciados, como a religiosidade. As imagens iconográficas e narrativas representam de modo positivo o negro e sua religiosidade.

O continente africano é evidenciado enquanto tal, com todas as suas riquezas e especificidades, em textos e gravuras.

Esses livros trazem referências para a constituição da identidade do povo negro, por meio da ancestralidade.

\section{Considerações}

Buscamos nesse artigo relatar a pesquisa etnográfica desenvolvida com os livros infantis e temática étnico-racial.

Os livros infantis analisados apresentam as relações históricas e culturais entre a África e o Brasil. Trazem um novo discurso centrado na concepção de nação e de cultura, onde a África é um continente e assume um lugar de extrema importância.

A diversidade cultural, a cultura negra e a religião são veiculadas por meio de discursos positivos em torno da identidade negra.

As narrativas resgatam a cultura africana trazendo crenças e mitos que continuam sustentando a identidade do povo negro e da sociedade brasileira.

$\mathrm{Na}$ análise empírica da pesquisa, pode-se constatar a existência de uma produção de livros infantis ainda pequena, após a promulgação da Lei n. ${ }^{\circ}$ 10.639/2003, mas que atende os pressupostos e a temática da pluralidade cultural. 
As obras infantis pesquisadas, apesar de serem poucas, propiciaram a vivência, a negritude, a preservação e a valorização da cultura afro-brasileira e africana, enfatizando o princípio da igualdade racial e perpetuando os conhecimentos ancestrais, principalmente os religiosos às novas gerações.

Os personagens são protagonistas das histórias e buscam sua vocação ontológica de humanizar-se.

A criança, ao se apropriar das narrativas, reconhece elementos de sua etnia, religião e tradição, podendo viver momentos de satisfação. Devemos reiterar que esses livros contribuem para o empoderamento das crianças negras que estavam inferiorizadas e oprimidas, possibilitando a relação entre as diferentes culturas e povos.

Dentre as características marcantes desses livros destacamos a valorização da memória do povo negro, sua cultura e imagem; a presença de contos africanos e da tradição africana; a possibilidade das temáticas abordadas dialogarem com as reflexões presentes sobre racismo e identidade brasileira; a presença de elementos que compõem a identidade do negro; a aproximação dos valores, costumes e hábitos do povo africano; uma reflexão para as crianças não negras de valorizar e respeitar a diversidade; convite a adentrar ao universo mítico africano e as relações com o universo.

Diante das análises dos livros infantis e a representação dos negros e das negras, entendemos que a nossa hipótese inicial de que o racismo estava operacionalizado nas obras de literatura infantil com temática étnico-racial depois de verificada não se confirmou.

\section{Referências}

DIOUF, A. S. As tranças de Bintou. Tradução de Charles Cosac. 2. ed. São Paulo: Cosac Naify, 2010.

FERNANDES, F. A integração do negro na sociedade de classes. São Paulo: Dominus, 1965. - A arqueologia do saber. Tradução de Luiz Felipe Baeta Neves. Rio de Janeiro: Forense Universitária, 2014b.

FOUCAULT, M. A ordem do discurso. São Paulo: Loyola, 2014a.

FREIRE, P. Pedagogia do Oprimido. São Paulo: Paz e Terra, 1987.

FREIRE, P. Educação: sonho possível. Em BRANDÃO, Carlos. Educador, vida e morte. Rio de Janeiro: Graal, 1989.

FREYRE, G. Casa Grande \& Senzala. Rio de Janeiro: Record, 2000.

JOVINO, I. da S. Literatura Infanto-juvenil com personagens negros no Brasil. In: SOUZA, F.; LIMA, M. N. (Org.).Literatura Afro-brasileira. Salvador: Centro de estudos afroorientais; Brasília, DF: Fundação Cultural Palmares, 2006.

LIMA, H. P. Histórias da Preta. Ilustrado por Laura Beatriz. São Paulo: Companhia das Letrinhas, 2010. 
MUNANGA, K. Identidade, cidadania e democracia: algumas reflexões sobre os discursos anti-racistas no Brasil. In: SPINK, Mary Jane Paris (Org.). A cidadania em construção: uma reflexão transdisciplinar. São Paulo: Cortez, 1994. p. 177-188.

PEIXOTO, F. L. Literatura Afro-brasileira. Salvador: Programa A Cor da Bahia, FFCH/UFBA, 2013.

QUIJANO, A. A colonialidade do saber: eurocentrismo e ciências sociais. Perspectivas latino-americanas. Buenos Aires: CLACSO, 1997.

ROSEMBERG, F. Relações raciais e rendimento escolar. Cadernos de Pesquisa, São Paulo, n. 63, p. 19-23, nov. 1987.

RUFINO, J. Gosto de África.São Paulo: Ed. Global.1998.

SOUZA NETO, João Clemente de. Crianças e adolescentes abandonados, estratégias de sobrevivência. São Paulo: Expressão e Arte, 2002.

TURCHI, Maria Zaira. Espaços da crítica da literatura infantil e juvenil. In: TURCHI, Vera M. Tietzmann (Orgs.) Leitor formado, leitor em formação: leitura literária em questão. São Paulo: Cultura Acadêmica editora, 2006. 


\title{
Relações étnico-raciais afro-brasileiras: teses e dissertações produzidas no Programa de Pós-Graduação em Ciência da Religião da Universidade Federal de Juiz de Fora
}

\author{
Ethnic-racial relations african-Brazilian: theses and dissertations produced in the Graduate \\ Program in Religious Science from the Federal University of Juiz de Fora
}

\author{
Vanessa Gomes de Castro ${ }^{5}$ \\ vadecastro@hotmail.com
}

\begin{abstract}
Resumo: O objetivo geral da presente pesquisa é refletir sobre a produção de conhecimento científico, especialmente, referente às relações étnico-raciais afro-brasileiras. O objetivo específico é realizar essa reflexão tomando como exemplo as dissertações e teses produzidas no Programa de Pós-Graduação em Ciência da Religião da Universidade Federal de Juiz de Fora (PPCIR/UFJF), desde a sua implantação até o ano de 2018. Diante disso, busca-se compreender tal produção à luz do conceito de "campo". Observa-se que, nos últimos anos, é crescente a produção científica sobre o tema das relações étnico-raciais afro-brasileiras no PPCIR/UFJF, sobretudo, no que tange à religiosidade de matriz afro, ajudando a fortalecer esse campo de conhecimentos.
\end{abstract}

Palavras-chave: Conhecimento Científico. Ciência da Religião. Relações étnico-raciais afrobrasileiras.

Abstract: This research intent is to reflect on the production of scientific knowledge, remarkably regarding Afro-Brazilian ethnic-racial relations. As the specific purpose, dissertations and theses produced in the Graduate Program in Science of Religion of the Federal University of Juiz de Fora (PPCIR / UFJF) from its implementation until 2018 were taken for this consideration. Hence, it seeks out to comprehend the productions under the "field" concept. In the last years it is noticed the grow in the scientific production related to the ethnic-racial afro-brazilian relations in PPCIR/UFJF mainly regarding to Afro matrix religiosity, enhancing this field of knowledge.

Keywords: Scientific knowledge; Science of religion; Afro-brazilian ethnic-racial relations

\section{Introdução}

A presente pesquisa parte das seguintes perguntas: Qual o lugar que a temática das relações étnico-raciais afro-brasileiras tem ocupado no campo de produção científica? No âmbito institucional, quem são os atores que têm fomentado a sua produção? Quais os temas mais recorrentes em relação à referida temática e quais as lacunas? O conhecimento científico, enquanto um fenômeno da sociedade moderna, é o saber que se baseia em análises consideradas racionais, metódicas e sistemáticas, de fatos reais e empiricamente

\footnotetext{
${ }^{5}$ Doutora em Ciências Sociais pelo Programa de Pós-graduação em Ciências Sociais da Universidade Federal de Juiz de Fora. Contato: vadecastro@hotmail.com
} 
comprováveis. Tal saber é legitimamente produzido pelas universidades (especialmente pelos Programas de Pós-Graduação) e pelos Institutos de Pesquisas. Diante disso, o objetivo específico desta pesquisa é realizar um exercício empírico, tomando como exemplo as dissertações e teses produzidas no Programa de Pós-Graduação em Ciência da Religião da Universidade Federal de Juiz de Fora, desde a sua implantação até o ano de 2018, cujo tema perpasse as relações étnico-raciais afro-brasileiras, especialmente, a religiosidade de matriz afro.

Há muito tempo os questionamentos sobre a produção social de conhecimento científico despertam a atenção de pesquisadores. É crescente o número de estudos sobre a produção de conhecimento científico, cuja necessidade de avaliação dos trabalhos, dos objetos de estudos, dos produtos e produtores das pesquisas, dos processos de divulgação científica, dentre outros aspectos, têm culminado na evolução de todo um campo de investigação. Na verdade, mais que um campo, pois os pesquisadores que se lançam à tarefa de investigar a produção do conhecimento científico adotam diferentes abordagens teóricas e metodológicas, seja na Sociologia da Ciência, História da Ciência, dentre outras áreas. Na Sociologia da Ciência, dentre os principais autores dedicados à investigação sobre as condições de produção científica, destaca-se Pierre Bourdieu.

De acordo com Bourdieu (2003), para compreendermos a produção científica não basta referirmo-nos somente ao texto e ao contexto social mais amplo desta produção, mas, também é preciso supor que o mundo particular de produção da ciência, no qual estão inseridos os agentes e as instituições que produzem, reproduzem e difundem a ciência, possui lógicas internas próprias. Esse mundo intermediário onde a ciência é produzida, chamado por Bourdieu (1983) de campo, é um espaço hierarquizado, um microcosmo dotado de leis próprias. Desta forma, o campo de produção da ciência pode ser considerado um mundo particular, e, como tal, faz imposições que são relativamente independentes das pressões do universo social mais amplo que o envolve.

Bourdieu (1983) argumenta que, no campo, há um permanente embate para conservar ou transformar suas características e relações de dominação. Em cada campo se encontram lutas entre os pretendentes e os dominantes, lutas entre os estabelecidos e aqueles que estão chegando. Os dominantes tendem a estabelecer monopólios e a excluir a concorrência. Esses conflitos rompem com a ideia de comunidade científica pacífica. Aqueles que monopolizam o capital científico tendem a conservar o status quo, enquanto os que possuem menos capital, os recém-chegados, os mais jovens, tendem à subversão. Assim, o campo de produção científica é detentor de um conjunto de práticas, normas, valores, estilos, gostos e restrições, que 
estabelecem o habitus que configura as condições sociais de produção científica (BOURDIEU, 1983; 2003).

Assim, é a estrutura de relações objetivas entre os diferentes agentes que determina o que eles podem ou não fazer. No campo da produção científica, isso significa os temas de pesquisas a serem privilegiados, as abordagens teóricas e metodológicas adotadas, os veículos ideais para publicação, dentre outros. Nesta direção, a posição que as instituições e os pesquisadores ocupam na estrutura do campo é que determina ou orienta suas tomadas de decisões. Para compreendermos o que dizem ou fazem, precisamos saber o seu lugar no campo, de onde ele fala no campo. Ou seja, não basta compreender somente o lugar da instituição ou do agente na estrutura social global, mas, também, o lugar que essa instituição e seus agentes ocupam na estrutura de um campo específico (BOURDIEU, 2003).

No campo da produção científica, segundo Bourdieu (2003), podemos caracterizar as instituições de produção de ciência e os seus pesquisadores pelo volume de capital científico possuído. Bourdieu (2003) destaca dois tipos de capital científico: o primeiro, o poder ou potencial político, é o poder institucional e institucionalizado, ligado a posições importantes no campo, ao poder sobre os meios de produção (recursos) e reprodução (poder de nomear e fazer carreiras). O segundo tipo de capital científico é simbólico, relacionado ao prestígio e status no campo. Está relacionado a recursos imateriais, como o conhecimento e o reconhecimento dos pares, isto é, ao prestígio, o qual pode ser acumulado e disputado. A quantidade de capital científico situa as instituições e os pesquisadores na estrutura do campo de produção da ciência (BOURDIEU, 2003).

No Brasil, historicamente, os negros foram excluídos e silenciados no campo de produção de conhecimentos científicos. Na verdade, não somente no campo de produção de conhecimento científico, mas, também, em todos os âmbitos da sociedade brasileira. No país, o contexto em que se organizaram as relações étnico-raciais afro-brasileiras é perverso. Como já se sabe, entre os séculos XVI e XIX, milhares de negros foram traficados da África para o Brasil, sendo arbitrariamente desenraizados de sua terra natal, escravizados, coisificados, mal tratados e explorados em sua mão de obra. A exploração da mão de obra dos negros escravizados movimentou a economia brasileira por mais de trezentos anos, entre 1500 e 1800. O Brasil constituiu a primeira, a maior e a mais duradoura sociedade escravista das Américas. Somente em 13 de maio de 1888 é que o regime escravocrata foi legalmente abolido no país, com a assinatura da Lei Áurea (FICHER, GRINBERG, MATTOS, 2018).

Nesse contexto, apesar das tentativas de resistência por parte dos negros escravizados, por exemplo, por meio de fugas, revoltas, formação de quilombos, etc., bem como a 
solidariedade dos abolicionistas, a extinção da escravidão aconteceu de forma lenta e gradual, por meio da promulgação de diversas leis (como a Lei dos Sexagenários, a Lei do Ventrelivre, a própria Lei Áurea), as quais, apesar da aparente libertação, não proporcionaram as condições sociais adequadas para a inserção dos negros na sociedade pós-abolicionista. Desta forma, a abolição da escravatura, por um lado, representou uma ruptura com o estatuto jurídico do regime escravocrata. Por outro lado, foi incapaz de transformar as profundas desigualdades econômicas e sociais, bem como responder ao racismo que se perpetrou para manter o status quo (FICHER, GRINBERG, MATTOS, 2018).

$\mathrm{O}$ racismo que nasce no país associado à escravidão, consolida-se mesmo após a abolição, com base em teses sobre a inferioridade biológica dos negros, difundidas no país como matriz para a interpretação do desenvolvimento nacional. As interpretações higienistas e eugênicas, amplamente adotadas pela sociedade brasileira, vigoraram entre o final do século XIX e início do século XX e estiveram presentes na base da formulação de políticas públicas que contribuíram, efetivamente, para o aprofundamento das desigualdades raciais no país (THEODORO, 2008). Por outro lado, a partir da década de 1930, pesquisadores como Gilberto Freyre atuaram na propagação dos princípios da cordialidade racial do Brasil e da ausência de desigualdade racial institucionalizada, isto é, o mito da democracia racial, contribuindo para o silenciamento das relações raciais, sobretudo, os conflitos (FICHER, GRINBERG, MATTOS, 2018).

Ao longo do século XX, foram desenvolvidos alguns grandes estudos sobre os negros no Brasil, por exemplo, nas obras de Gilberto Freyre, Edson Carneiro, Arthur Ramos, Florestan Fernandes, Fernando Henrique Cardoso, Oracy Nogueira, dentre outros. A primeira dissertação de mestrado sobre as relações étnico-raciais foi defendida em 1945, na Escola Livre de Sociologia e Política de São Paulo, com o título "Estudo de atitudes raciais de pretos e mulatos em São Paulo", com autoria de Virginia Leone Bicudo. A partir dos anos 1950, muitas das pesquisas sobre relações étnico-raciais no Brasil foram incentivadas e financiadas pela UNESCO, que via no país a existência de uma "democracia racial exemplar" (MELLATI, 1983). Foi, sobretudo, a partir da década de 1980, com a resistência dos movimentos negros, a promulgação da nova Constituição da República em 1988 e a instituição do Estado Democrático e de Direitos, que as estruturas jurídicas brasileiras começaram a ser, de fato, transformadas, no sentido de tornarem visíveis as desigualdades raciais, incompatíveis com o governo democrático (FICHER, GRINBERG, MATTOS, 2018).

Dentre os principais fundamentos da Constituição de 1988, encontra-se a promoção do bem estar de todos, sem preconceitos de origem, sexo, cor, idade e quaisquer outras formas de 
discriminação. Nesse cenário, as denúncias do mito da democracia racial proliferaram entre organismos governamentais. Ativistas e políticos passaram a propor diversas medidas e ações afirmativas que demonstram a importância da identidade racial, quebrando o silêncio institucional do Brasil sobre os legados da escravidão e do racismo. Os movimentos negros passaram a dialogar mais com o Estado e com a sociedade civil, angariando vitórias fundamentais à democratização dos seus direitos (FICHER, GRINBERG, MATTOS, 2018). A questão racial tornou-se uma pauta importante na agenda da política nacional. Como consequência, nas últimas décadas, diversos instrumentos e políticas de promoção da igualdade racial têm sido implantados e intensificados por todo o país (HERINGER, 2002; DOMINGUES, 2007, LIMA, 2010; FICHER, GRINBERG, MATTOS, 2018).

Ao final do século XX e início do século XXI, assistimos à implementação de medidas como a Lei 7.716/1989, que define os crimes resultantes de preconceito de raça e de cor; a Lei $\mathrm{n}^{\circ}$ 10.678/2003, que cria a Secretaria de Políticas de Promoção da Igualdade Racial (SEPPIR); a Lei $\mathrm{n}^{\mathrm{o}} 10.639 / 2003$, que torna obrigatório o ensino de conteúdos relacionados à história e às culturas africana e afro-brasileira nas escolas públicas e privadas de educação básica; a Lei ${ }^{\circ}$ 11.645/2008, que estabelece as diretrizes e bases da educação nacional para incluir no currículo oficial da rede de ensino a obrigatoriedade da temática história e cultura afrobrasileira e indígena; a Lei ${ }^{\circ} 12.288 / 2010$, que institui o Estatuto da Igualdade Racial; a Lei $\mathrm{n}^{\mathrm{o}} 12.711 / 2012$, que garante aos negros a reserva de $50 \%$ das matrículas por curso e turno nas universidades e institutos federais de educação, ciência e tecnologia; a Lei nº 12.990/2014, que prevê a reserva de $20 \%$ das vagas oferecidas nos concursos públicos federais aos negros, dentre outras. Tais medidas devem ser consideradas grandes conquistas na luta pela igualdade racial no Brasil, embora as desigualdades raciais no país permaneçam marcantes.

Neste cenário, a universidade brasileira, desde a sua origem, mantém em seu corpo docente e discente uma hegemonia de cor, sendo um espaço predominantemente de brancos, preocupados, sobretudo, com os problemas de brancos; ou quando estão preocupados com os problemas de negros, ocupam o lugar de fala de branco. Como bem observa Carvalho (2002), a ausência de acadêmicos negros entre os quadros das universidades brasileiras, produzindo conhecimento e reflexão sobre as questões negras, comprometeu a capacidade das instituições de refletir com isenção sobre a sua própria política racial e de se autoavaliar adequadamente a esse respeito. Diante disso, as teorias e as interpretações das relações raciais no Brasil, sempre foram racializadas. Essa condição de exclusão racial extrema do mundo acadêmico deve ser levada em conta na hora de refletirmos sobre os modelos de interpretação das relações raciais no Brasil e as condições sociais de produção de conhecimento científico. Nesse contexto, a 
persistente reivindicação dos movimentos negros e medidas como a adoção de ações afirmativas busca uma atenuação da desigualdade de cor no meio acadêmico. Nesse processo, voltam-se o olhar para objetos de pesquisas focados na situação histórica, econômica, política, social e cultural dos negros na sociedade brasileira no interior do campo científico (CARVALHO, 2002; 2006).

Diante disso, nos últimos anos, diversas pesquisas, seja no âmbito da graduação ou pós-graduação, a partir de trabalhos de conclusão de curso, dissertações e teses, em diferentes áreas de conhecimento, têm buscado investigar a produção científica sobre as várias dimensões que compõem as relações étnico-raciais afro-brasileiras, por exemplo, os trabalhos de Santos e Santos (2016), Cardoso, Santos e Rodrigues (2017), Artes e Mena-Chalco (2017), Rodrigues, Monagreda e Porto (2017), dentre outros. Assim, a presente pesquisa busca refletir sobre a produção de conhecimento científico, sobretudo, o lugar que a temática afro tem ocupado no campo de produção da ciência, tomando como exemplo as dissertações e teses defendidas no Programa de Pós-graduação em Ciência da Religião da Universidade Federal de Juiz de Fora (PPCIR/UFJF).

A Universidade Federal de Juiz de Fora (UFJF) foi fundada em 1960, porém, somente a partir dos anos 1990 é que foram instituídos os programas de pós-graduação stricto sensu (mestrado e doutorado). Atualmente, segundo o site da Pró-reitoria de Pós-graduação da UFJF, a instituição conta com 45 programas de pós-graduação. Além disso, destaca-se também que, desde 2008, a UFJF conta com um Núcleo de Estudos Afro-Brasileiros (NEAB), um órgão suplementar da Universidade Federal de Juiz de Fora, vinculado à Pró-Reitoria de Pesquisa, que busca promover a participação de docentes, discentes, pesquisadores e servidores de todos os departamentos e unidades acadêmicas. $\mathrm{O}$ núcleo tem como proposta $\mathrm{o}$ desenvolvimento de um diálogo contínuo e participativo dos diversos segmentos do Movimento Negro da cidade, com representantes em seu conselho deliberativo. Já o Departamento de Ciência da Religião da Universidade Federal de Juiz de Fora iniciou suas atividades 1969. Em 1993 teve início o mestrado. Em 1999 foi aprovado o doutorado. O PPCIR mantém o conceito cinco na CAPES (Coordenação de Aperfeiçoamento de Pessoal de Nível Superior).

\section{Metodologia}

A unidade de análise são as dissertações e teses defendidas no Programa de Pósgraduação em Ciência da Religião da Universidade Federal de Juiz de Fora (PPCIR/UFJF), 
desde a sua fundação até setembro de 2018. Para localizar os trabalhos, são utilizados os sites do Repositório Institucional da UFJF, do Catálogo de teses e dissertações da Capes e do Programa de Pós-graduação em Ciência da Religião da UFJF. A Biblioteca da UFJF também foi consultada. Os descritores utilizados para identificar os trabalhos são: africano; afrobrasileiro; negro; afrodescendente; quilombo; racismo; escravidão; congado; umbanda; candomblé. Para verificar o perfil dos professores orientadores são utilizadas as informações contidas no Currículo Lattes. O modelo de análise considera a quantidade de trabalhos, isto é, o número de teses e dissertações defendidas no PPCIR/UFJF e as suas características tais como título do trabalho, palavras-chave, objetivo geral, tema, ano, programa, orientador, linha de pesquisa, doutorado do orientador, ano de obtenção do doutorado do orientador, título da tese do orientador, área de atuação do orientador, desde quando o orientador é professor efetivo na UFJF.

\section{Resultados}

Considerando os dados contidos no Repositório Institucional da Universidade Federal de Juiz de Fora (UFJF), no site do Programa de Pós-Graduação em Ciência da Religião (PPCIR/UFJF) e no Catálogo de Teses e Dissertações da Capes, foram localizadas, até setembro de 2018, vinte e duas dissertações e seis teses cujos temas de pesquisa estão relacionados à religiosidade de matriz afro. O primeiro gráfico apresenta o número de dissertações defendidas na UFJF (4940), o número de dissertações defendidas no PPCIR/UFJF (304) e o número de dissertações defendidas no PPCIR/UFJF especificamente relacionadas à religiosidade afro (22). Observa-se que o total de trabalhos sobre religiosidade afro representa aproximadamente $7 \%$ em relação ao total de dissertações defendidas no PPCIR/UFJF e $0,4 \%$ do total de dissertações defendidas na Universidade Federal de Juiz de Fora: 
Gráfico 01: Total de dissertações defendidas

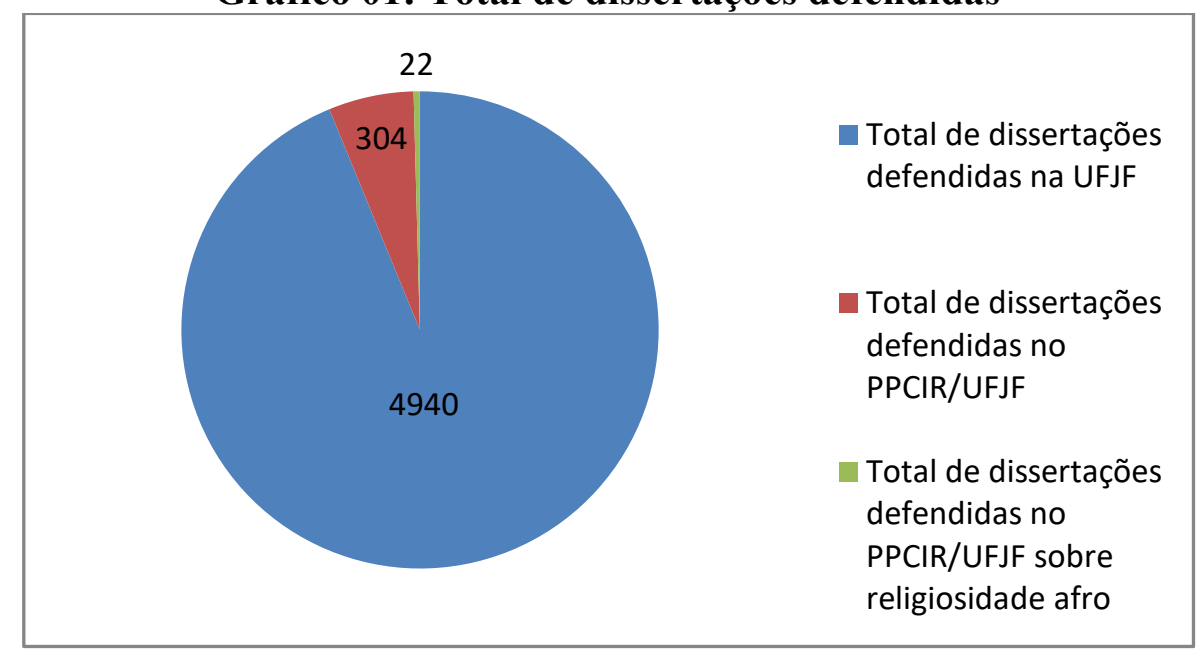

Fonte: Elaboração do autor.

O segundo gráfico mostra o total de teses defendidas na UFJF (797), teses defendidas no PPCIR/UFJF (115) e teses defendidas no PPCIR/UFJF relacionadas à religiosidade afro (6). Nota-se que as teses sobre religiosidade afro representam 5\% das teses defendidas no PPCIR/UFJF e 0,7\% das teses defendidas na UFJF. Sem sombra de dúvidas, essas dissertações e teses são de grande importância para o campo de estudos sobre as relações étnico-raciais afro-brasileiras, porém, ainda são poucas as pesquisas perto das diversas dimensões culturais, sociais e políticas que $\mathrm{p}$

erpassam as religiosidades de matriz afro.

\section{Gráfico 02: Total de teses defendidas}

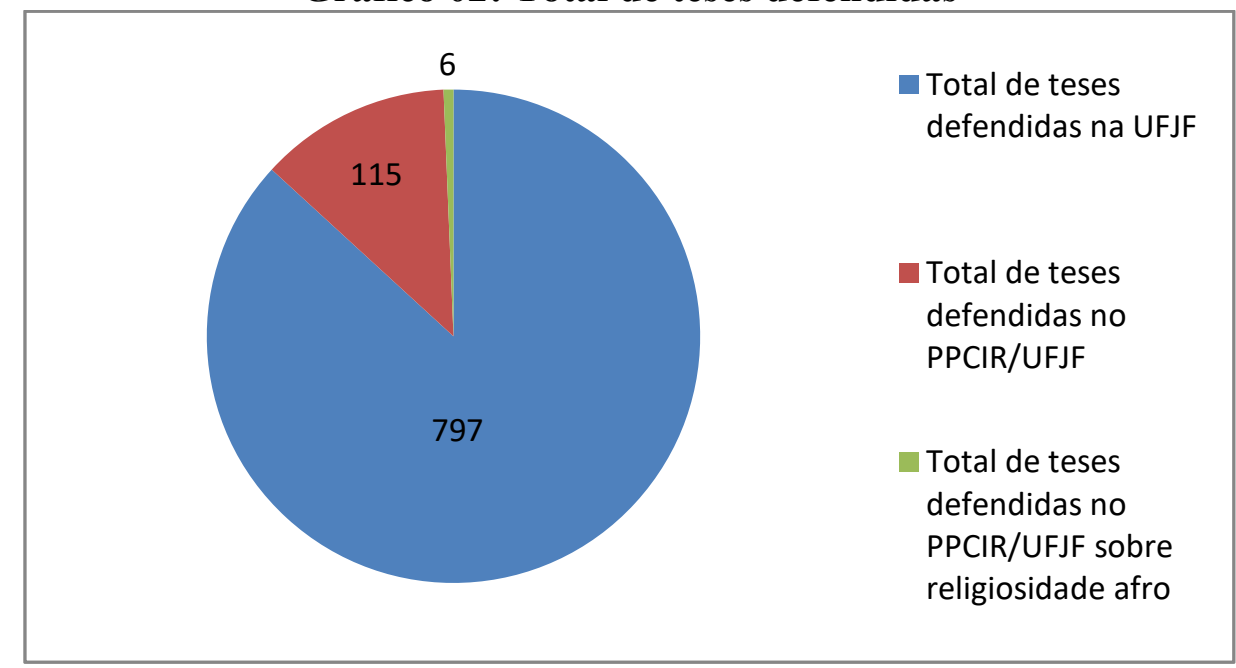

Fonte: Elaboração do autor.

O terceiro gráfico mostra o total de dissertações defendidas no PPCIR/UFJF, relacionadas à referida temática, por ano. Observa-se que a primeira dissertação sobre 
religiosidade afro defendida no PPCIR/UFJF foi no ano de 1996, intitulada "Os Tambores Estão Frios: Herança Cultural e Sincretismo Religioso no Ritual do Candombe", sendo a autoria de Edmilson de Almeida Pereira e a orientação do Professor Doutor Faustino Luiz Couto Teixeira. Em linhas gerais, a pesquisa buscou examinar os aspectos linguísticos, históricos e antropológicos do Candombe, ritual que integra as celebrações do congado em Minas Gerais, cuja estrutura revela ligações entre as práticas sagradas dos afrodescendentes e os fatos sociais do Brasil, nos períodos escravista e pós-escravista. Apesar da dissertação mais antiga ter sido defendida na década de 1990, não houve uma regularidade de trabalhos nos anos seguintes. Somente entre 2011 e 2018 é que tem sido defendida pelo menos uma dissertação sobre religiosidade de matriz afro, por ano. $\mathrm{O}$ ano que mais tiveram dissertações defendidas sobre a referida temática foi 2015, com três trabalhos. A dissertação mais recente foi defendida no ano de 2018.

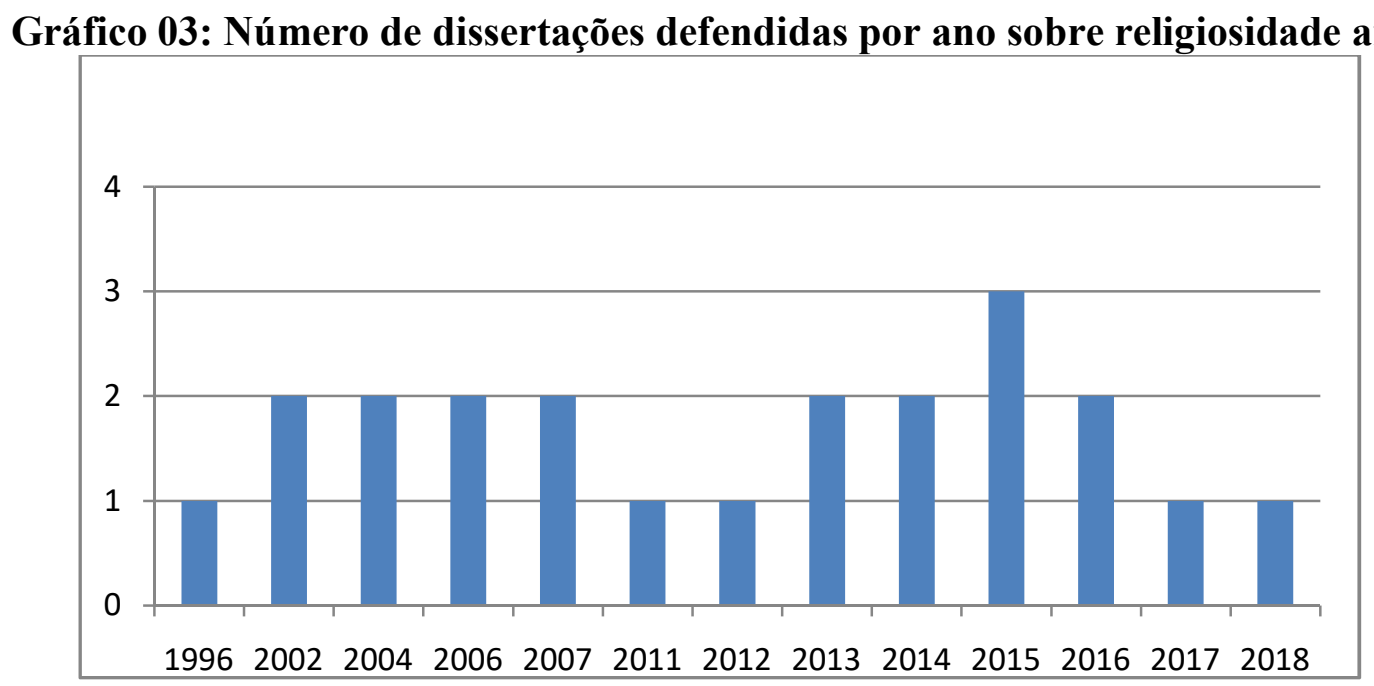

Fonte: Elaboração do autor.

O quarto gráfico mostra o total de teses defendidas no PPCIR/UFJF, relacionadas à referida temática, por ano. A primeira tese sobre religiosidade afro defendida no PPCIR/UFJF foi no ano de 2009, intitulada "Religiões de matriz africana em Juiz de Fora: trajetórias, alianças e conflitos", de autoria de Maria da Graça Floriano e orientação de Fátima Regina Gomes Tavares. Observa-se que em 2018, já foram defendidas três teses que perpassam a religiosidade afro, uma quantidade maior do que os anos anteriores. 


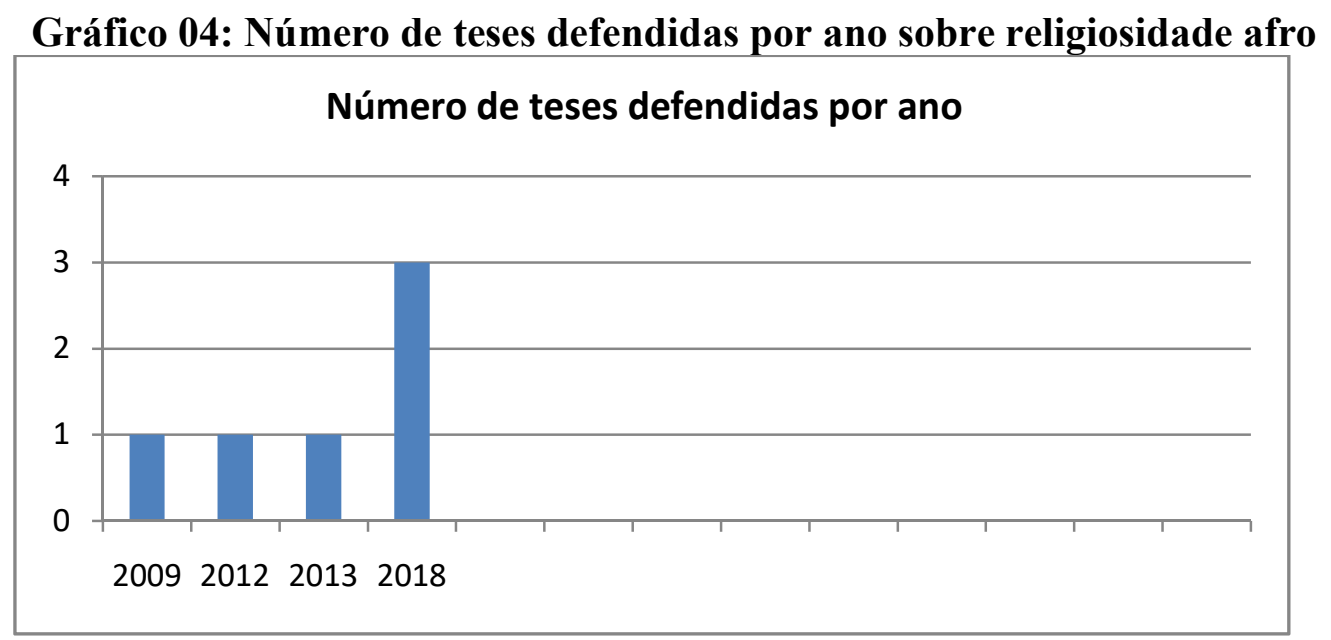

Fonte: Elaboração do autor.

O próximo quadro traz os títulos das vinte e duas dissertações defendidas no PPCIR/UFJF, relacionadas à religiosidade afro, por ano, identificadas por essa pesquisa. Ressalta-se que os temas recorrentes são, respectivamente, umbanda, candomblé, congado, irmandade, catolicismo afro, folia de reis e candombe.

\section{Quadro 01: Títulos das dissertações defendidas no PPCIR/UFJF que abordam a religiosidade de matriz afro}

\begin{tabular}{|c|c|}
\hline TÍTULOS DAS DISSERTAÇÕES & ANO \\
\hline Os Tambores Estão Frios: Herança Cultural e Sincretismo Religioso no Ritual do Candombe & 1996 \\
\hline Afinidades e distanciamentos entre os movimentos espírita e umbandista sob a perspectiva da caridade & 2002 \\
\hline Exu - Luz e Sombras: Uma análise psico-junguiana da linha de exu na Umbanda & 2002 \\
\hline A Boca e o Sagrado: A Comida de Santo no Candomblé, a Comunicação entre os Seres Humanos e os Orixás & 2004 \\
\hline Umbandistas de cabeça feita: uma análise do trânsito religioso entre umbandistas e candomblecistas em Juiz de Fora & 2004 \\
\hline Folia de Reis em Leopoldina: uma encruzilhada religiosa, artística e cultural & 2005 \\
\hline $\begin{array}{l}\text { Feitiços e Feiticeiros: Repressão à Tradição Religiosa Afro-brasileira na Juiz de Fora do Primeiro Código Penal } \\
\text { Republicano (1890-1942) }\end{array}$ & 2006 \\
\hline Iemanjá e pomba-gira: imagens do feminino na umbanda & 2006 \\
\hline De fora do terreiro: o discurso católico e kardecista sobre a Umbanda entre 1940 e 1965 & 2007 \\
\hline Festas, cortejos, procissões: tradição e modernidade no congado belo-horizontino & 2007 \\
\hline O reinado nas encruzilhadas do catolicismo: a dinâmica das comunidades congadeiras em Itaúna/MG & 2011 \\
\hline O cruzeiro e suas histórias cruzadas: devoções e experiências entre a umbanda e o catolicismo em Juiz de Fora & 2012 \\
\hline A festa de Nossa Senhora do Rosário de Paula Cândido (MG): identidade, memória e ritual no Congado e no Reinado & 2013 \\
\hline $\begin{array}{l}\text { Sincretismos, negociações e conflitos: apropriação e inversão do catolicismo nas Irmandades Negras de Nossa } \\
\text { Senhora do Rosário na Minas Gerais do século XVII }\end{array}$ & 2013 \\
\hline $\begin{array}{l}\text { Irmandades Católicas no Século XXI: Irmandade de Nossa Senhora do Rosário do Paissandu de São Paulo e } \\
\text { Irmandade do Rosário de Nossa Senhora do Rosário do Ouro Preto }\end{array}$ & 2014 \\
\hline O diálogo intra-religioso na umbanda: um estudo a partir da figura do caboclo & 2014 \\
\hline Entre a Casa Grande e a Senzala: a formação da religiosidade brasileira na perspectiva de Gilberto Freyre & 2015 \\
\hline $\begin{array}{l}\text { O discurso religioso dos afrodescendentes da localidade de São José das Três Ilhas: memórias herdadas, identidades } \\
\text { em construção }\end{array}$ & 2015 \\
\hline $\begin{array}{l}\text { O trânsito religioso protagonizado por umbandistas e candomblecistas no Terreiro do Pai Carlinhos Cabral de Oxum: } \\
\text { uma análise da convivência religiosa dentro de um terreiro misto em Juiz de Fora }\end{array}$ & 2016 \\
\hline Saúde, doença e cura em cultos umbandistas: estudo de caso em um terreiro de umbanda na cidade de Juiz de Fora & 2016 \\
\hline A umbanda e seu novo espaço: o terreiro virtual - um estudo de caso & 2017 \\
\hline Pelo sinal da cruz, ao som do tambor: interfaces da experiência religiosa no Co & 2018 \\
\hline
\end{tabular}

Fonte: Elaboração do autor. 
O quadro seguinte traz os títulos das seis teses defendidas no PPCIR/UFJF, relacionadas à religiosidade afro. Os temas perpassam, principalmente, o catolicismo, o candomblé, o congado, além de outros aspectos relacionados à religião.

\section{Quadro 02: Títulos das teses defendidas no PPCIR/UFJF que abordam a} religiosidade de matriz afro

\begin{tabular}{|l|c|}
\hline \multicolumn{1}{|c|}{ TÍTULOS DAS TESES } & ANO \\
\hline Religiões de matriz africana em Juiz de Fora: trajetórias, alianças e conflitos & 2009 \\
\hline $\begin{array}{l}\text { Àròyé: um estudo histórico-antropológico do debate entre discursos católicos e do candomblé no pós- } \\
\text { Vaticano II }\end{array}$ & 2012 \\
\hline $\begin{array}{l}\text { Visitações episcopais: o projeto católico de evangelização e as mulheres negras forras em Mariana 1722- } \\
1793\end{array}$ & 2013 \\
\hline A fé que dança e (em)canta: análise das experiências religiosas de congadeiros nas minas de Minas & 2018 \\
\hline $\begin{array}{l}\text { A religião para além das fronteiras religiosas: uma análise das trajetórias de Martin Luther King Jr e } \\
\text { Mohandas Karanchand Gandhi a partir do projeto Weltethos (ética mundial) }\end{array}$ & 2018 \\
\hline Mulheres negras: religiosidade, atividades artístico-culturais, consciência & 2018 \\
\hline
\end{tabular}

Fonte: Elaboração do autor.

No que concerne ao perfil dos professores orientadores, nota-se que sete nomes concentram as orientações relacionadas à temática da religiosidade afro no PPCIR/UFJF. Os orientadores recorrentes são os professores doutores Emerson José Sena da Silveira, Fátima Regina Gomes Tavares, Faustino Luiz Couto Teixeira, Francisco Luiz Pereira da Silva Neto, Marcelo Ayres Camurça, Robert Daibert Júnior e Volney José Berkenbrock. Observa-se que o Professor Doutor Volney José Berkenbrock concentra a maior quantidade de orientações de dissertação.

Gráfico 05: Professores que orientaram dissertações relacionadas à religiosidade afro no PPCIR/UFJF

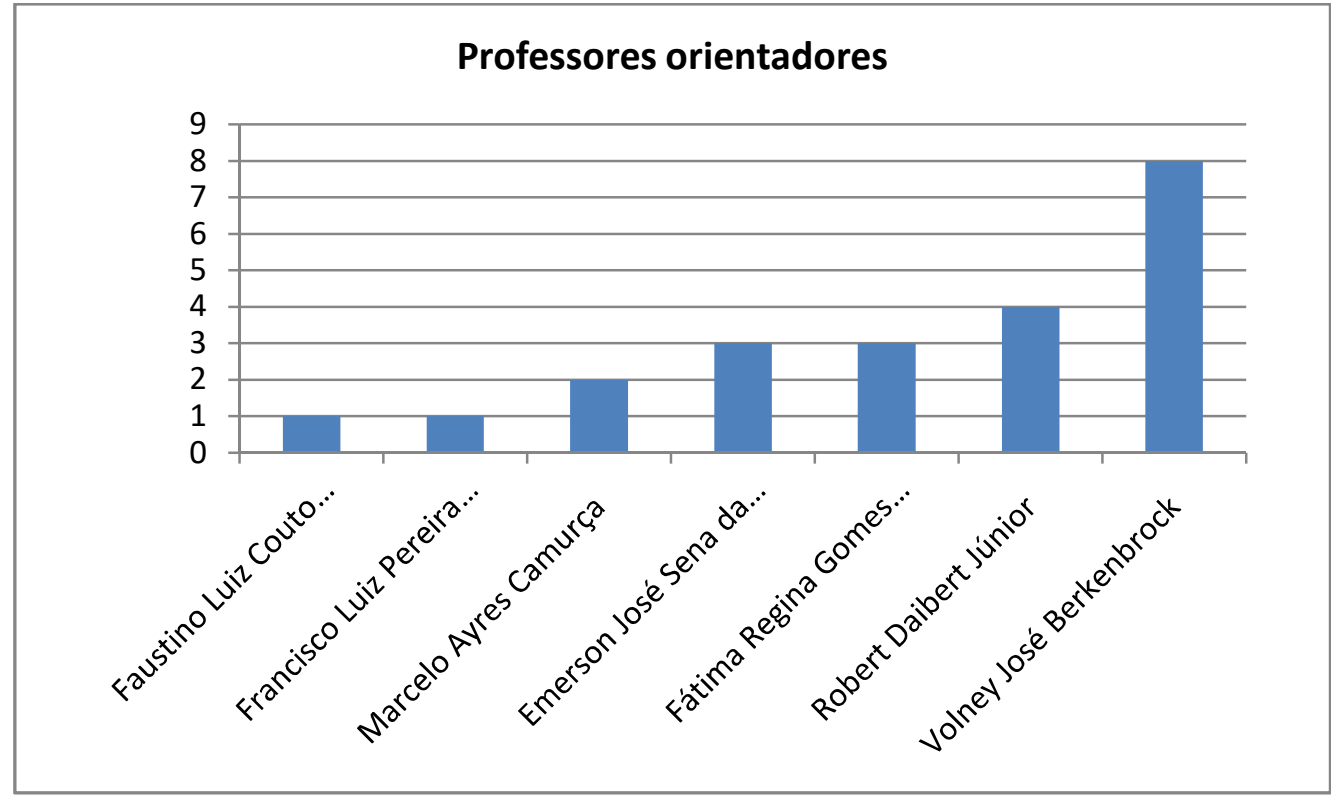

Fonte: Elaboração do autor. 
Em relação às seis teses defendidas no PPCIR/UFJF que tratam da temática mencionada, os orientadores foram os professores doutores Fátima Regina Gomes Tavares, Emerson José Sena da Silveira, Volney José Berkenbrock e Robert Daibert Júnior. Nota-se que o professor Doutor Robert Daibert Júnior concentra a maior quantidade de orientações de teses.

Gráfico 06: Professores que orientaram teses relacionadas à religiosidade afro no PPCIR/UFJF

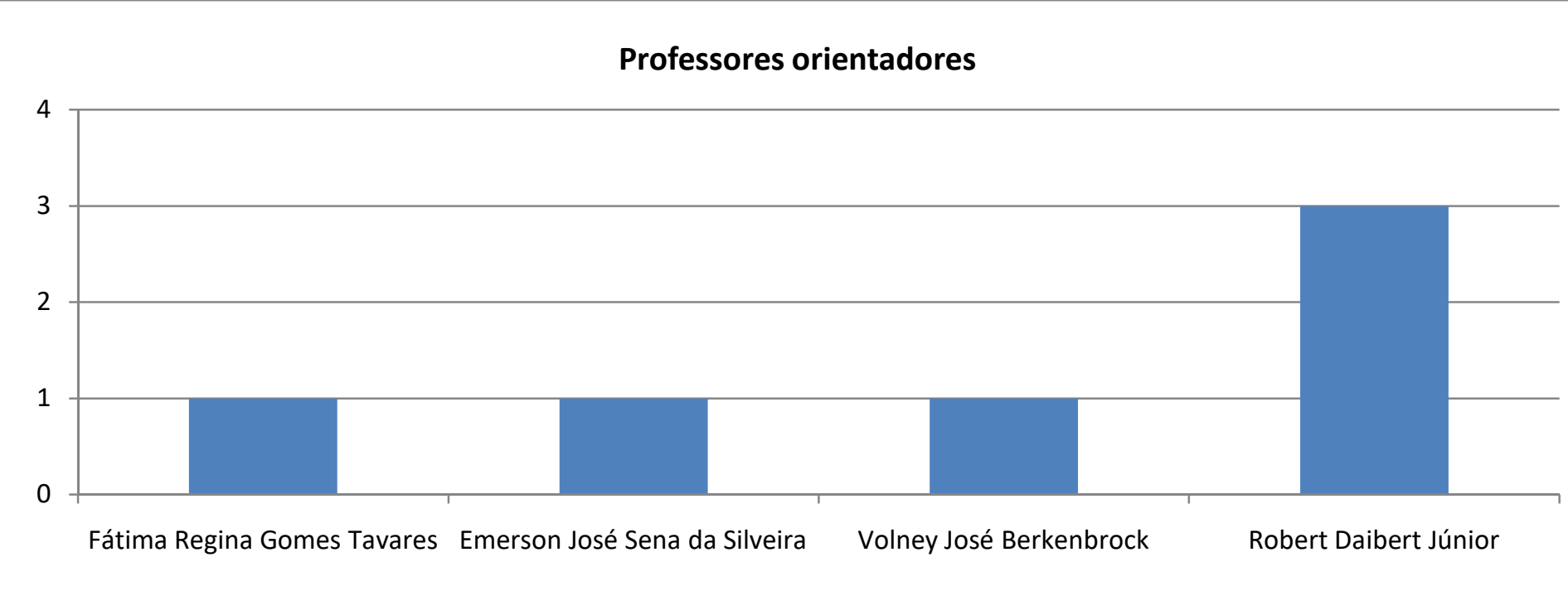

Fonte: Elaboração do autor.

De acordo com o Currículo Lattes, os referidos professores tornaram-se efetivos na UFJF entre 1989 e 2010. A formação acadêmica dentre eles varia entre Doutorado em Antropologia Social, Ciência da Religião, História e Teologia. Os títulos de doutor foram obtidos entre 1985 e 2007. Ainda em relação aos orientadores, pelo menos dois escreveram teses relacionadas diretamente com questões africanas e afro-brasileiras. Volney José Berkenbrock, cuja tese "Die Erfahrung der Orixa", trata da experiência dos orixás, isto é, a experiência religiosa no candomblé. E Robert Daibert Júnior, "Princesa Isabel (1846-1921): a política do coração entre o trono e o altar", o qual trabalhou com representações sobre a Princesa no Isabel no contexto da abolição. No currículo Lattes desses dois professores, no que tange a área de atuação e as linhas de pesquisa, consta especificamente a especialidade em religiões afro-brasileiras. Os dois professores mencionados concentram a maior quantidade de orientações de trabalhos que tratam da religiosidade afro. 
Destaca-se também que o PPCIR/UFJF conta com quatro linhas de pesquisa: Abordagens Filosóficas e Psicológicas da Religião; Campo Religioso Brasileiro; Religião e Espaço Público; Religiões e Diálogo. Alguns dos professores mencionados participam de mais de uma linha de pesquisa, no entanto, todos integram a linha "Campo Religioso Brasileiro", que visa mapear, tipologizar e conceituar as características e dinâmicas das diversas religiões e religiosidades nas suas interações. Essa linha conta com o projeto de pesquisa "Identidade e tradição no movimento espírita e religiões afro-brasileiras", o qual visa estudar o espiritismo/kardecismo e as religiões afro-brasileiras em relação com a sociedade brasileira. O projeto reúne na equipe os professores doutores Robert Daibert Júnior (responsável), Marcelo Ayres Camurça Lima e Volney José Berkenbrock. Esses professores também participam do Núcleo de Estudos Afro-brasileiros (NEAB).

Dentre todos os professores que orientaram dissertações e teses relacionadas à religiosidade de matriz afro no PPCIR/UFJF, Faustino Luiz Couto Teixeira se aposentou como professor titular da Universidade Federal de Juiz de Fora em 2017, reingressando como professor convidado na mesma instituição, no Programa de Pós-Graduação em Ciência da Religião. Francisco Luiz Pereira da Silva atuou no PPCIR/UFJF de 2004 a 2009, e, atualmente, é professor adjunto de Antropologia da Universidade Federal de Pelotas. Marcelo Ayres Camurça, depois da aposentadoria no final de 2017, na condição de professor titular, reingressou na UFJF como professor visitante para atuar na Pós-Graduação e Pesquisa. Emerson José Sena da Silveira é professor do departamento de Ciência da Religião da UFJF, atuando no Programa de Pós-Graduação em Ciência da Religião (PPCIR).

Já a professora Fátima Regina Gomes Tavares ingressou no PPCIR/UFJF em 1999, onde permaneceu até 2008, sendo redistribuída para a Universidade Federal da Bahia em 2009, onde é professora titular no Departamento de Antropologia e Etnologia. Atualmente, coordena o projeto de pesquisa "Redes de Cuidado em Quilombos de Cachoeira, Baía de Todos os Santos". Robert Daibert Júnior é professor da Universidade Federal de Juiz de Fora, onde atua no Programa de Pós-graduação em História e no Programa de Pós-Graduação em Ciência da Religião. Atualmente, assumiu a função de vice-diretor do Instituto de Ciências Humanas da UFJF. Volney José Berkenbrock é professor no Departamento de Ciência da Religião de Universidade Federal de Juiz de Fora. Atualmente, coordena o projeto de pesquisa "A antropologia religiosa do candomblé".

Percebe-se que, dentre os professores que orientaram trabalhos relacionados à religiosidade afro, dois se aposentaram em 2017, embora tenham retornado como professores convidado e visitante em 2018; dois já não fazem parte do quadro docente da UFJF; três 
continuam atuando no PPCIR/UFJF, entretanto, também acumulando funções administrativas. Ou seja, o quadro de professores que orientaram trabalhos sobre o tema da religiosidade afro no PPCIR/UFJF tem sido desfalcado e não tem se renovado nos últimos anos.

\section{Considerações finais}

A presente pesquisa teve como objetivo geral refletir sobre a produção de conhecimento científico, especialmente referente às relações étnico-raciais afro-brasileiras. $\mathrm{O}$ objetivo específico foi realizar essa reflexão tomando como exemplo as dissertações e teses produzidas no Programa de Pós-Graduação em Ciência da Religião da Universidade Federal de Juiz de Fora, desde a sua implantação até o ano de 2018. Assim, a pesquisa se guiou pelas seguintes perguntas: Qual o lugar que a temática das relações étnico-raciais afro-brasileiras tem ocupado no campo de produção científica? No âmbito institucional, quem são os atores que têm fomentado a sua produção? Quais os temas mais recorrentes em relação à referida temática e quais as lacunas?

Em relação à primeira pergunta: qual o lugar que a temática das relações étnico-raciais afro-brasileiras tem ocupado no campo de produção científica? Ao realizar o levantamento dos dados notou-se que as produções sobre a referida temática tem ocupado um espaço cada vez maior e bem qualificado em relação à quantidade e a diversidade de trabalhos, tanto em formato de teses, dissertações, trabalhos de conclusão curso e etc. Ao examinar os dados do PPCIR/UFJF também é possível observar que a cada ano aumentam o número de dissertações e teses defendidas, cujos temas perpassam as religiosidades de matriz afro. Porém, diante de toda a riqueza dessa temática, das diversas dimensões (sociais, culturais e políticas) que compõem as religiosidades de matriz afro, bem como considerando os diferentes níveis em que elas acontecem (macro, meso e microssocial), há espaço para mais e diversificados trabalhos.

Quanto à segunda pergunta: no âmbito institucional, quem são os atores que têm fomentado a sua produção? Nota-se que, dentre aos atores que têm fomentado a produção científica sobre as relações étnico-raciais, especialmente, as religiosidades de matriz afro, a Universidade Federal de Juiz de Fora, o Programa de Pós-graduação em Ciência da Religião, bem como um grupo de docentes do PPCIR/UFJF, contribuem com a produção de dissertações e teses sobre o tema, mantendo um projeto de pesquisa sobre a temática da religiosidade afro, dentro de uma das linhas de pesquisa do PPCIR e também participando do Núcleo de Estudos Afro-brasileiros (NEAB), configurando-se aí um campo de estudos. 
No que se refere à terceira pergunta: quais os temas mais recorrentes em relação à referida temática e quais as lacunas? Conforme já mencionado, os temas recorrentes são respectivamente umbanda, candomblé, congado, irmandade, catolicismo afro, folia de reis e candombe. Todavia, permanecem lacunas, por exemplo, em relação aos estudos de outras religiosidades de matriz afro além dessas que foram citadas; recortes relacionados ao preconceito, discriminação e intolerância no que tange às religiosidades de matriz afro; assim como recortes voltados a discutir esses temas aplicados à educação.

Assim, ressalta-se, por um lado, um campo de estudos sobre as religiosidades de matriz afro, que vem se fortalecendo no PPCIR/UFJF, com professores comprometidos e com conhecimentos sobre o tema (embora esse quadro não esteja se renovando nos últimos anos), além, é claro, dos estudantes interessados. Por outro lado, destaca-se que, apesar da crescente quantidade de pesquisas é necessário ir mais e além.

\section{Referências}

ARTES, A.; MENA-CHALCO, J. Expansão da temática relações raciais no banco de dados de teses e dissertações da Capes. Educação e Pesquisa, São Paulo, v. 43, n. 4, p. 1221-1238, out./dez., 2017.

BOURDIEU, P. Questões de sociologia. Rio de Janeiro: Marco Zero; 1983.

BOURDIEU, P. Os Usos Sociais da Ciência: por uma sociologia clínica do Campo científico. São Paulo: Fundação Editora da UNESP, 2003.

BRASIL. Lei $\mathbf{n}^{0}$ 10.639, de 09 de janeiro de 2003. Disponível em: http://www.planalto.gov.br/ccivil_03/leis/2003/L10.639.htm Acesso em 20/04/2018. BRASIL. Lei $\mathbf{n}^{\circ}$ 10.678, de 23 de maio de 2003. Disponível em: http://www.planalto.gov.br/ccivil_03/leis/2003/L10.678.htm Acesso em 20/04/2018. BRASIL. Lei $\mathbf{n}^{\mathbf{0}}$ 11.645, de 10 de março de 2008. Disponível em: http://www.planalto.gov.br/ccivil 03/ ato2007-2010/2008/lei/111645.htm Acesso em 20/04/2018.

BRASIL. Lei $\mathbf{n}^{\mathbf{0}}$ 12.288, de 20 de julho de 2010. Disponível em: http://www.planalto.gov.br/ccivil_03/_Ato2007-2010/2010/Lei/L12288.htm. Acesso em 20/04/2018.

BRASIL. Lei $\mathbf{n}^{0}$ 12.711, de 29 de agosto de 2012. Disponível em: http://www.planalto.gov.br/ccivil 03/ ato2011-2014/2012/lei/112711.htm Acesso em 20/04/2018.

BRASIL. Lei no 12.990, de 09 de junho de 2014. Disponível em: http://www.planalto.gov.br/ccivil_03/_Ato2011-2014/2014/Lei/L12990.htm Acesso em 20/04/2018.

BRASIL. Lei $\mathbf{n}^{\mathbf{0}} \mathbf{7 . 7 1 6}$, de 05 de janeiro de 1989. Disponível em: http://www.planalto.gov.br/ccivil 03/leis/17716.htm Acesso em 20/04/2018.

CARDOSO, I. A.; SANTOS, F. V. S.; RODRIGUES, T. C. Relações étnico-raciais na produção científica do PPGE/UFSCar. Revista Eletrônica de Educação, v.11, n.1, p.68-85, jan./maio, 2017. 
CARVALHO, J. J. Exclusão racial na universidade brasileiro: um caso de ação negativa. In: QUEIROZ, D. M. (Coord.). O negro na universidade. Programa A cor da Bahia. Salvador: Novos Toques, n.5, p.81-99, 2002.

CARVALHO, J. J. O confinamento racial do mundo acadêmico brasileiro. Revista da USP, São Paulo, n. 68, p. 88-103, dez./jan./fev. 2005-2006.

DOMINGUES, P. Movimento Negro Brasileiro: alguns apontamentos históricos. Revista Tempo, Rio de Janeiro, v. 12, n. 23, p. 100-122, 2007. FICSHER B., GRINBERG, K E MATTOS, H. Direito, silêncio e racialização das desigualdades na História afro-brasileira. No Prelo, Cambridge, 2018. HERINGER, R. Desigualdades raciais no Brasil: síntese de indicadores e desafios no Campo das políticas públicas. Cadernos de Saúde Pública, Rio de Janeiro, v. 18, p. 57-65, 2002. LIMA, M. Desigualdades raciais e políticas públicas: ações afirmativas no governo Lula. Novos Estudos - CEBRAP, São Paulo, n. 87, p. 77-85, jul. 2010. MELATTI, J. C. A Antropologia no Brasil: Um Roteiro. Boletim Informativo em Ciências Sociais. Rio de Janeiro: $\mathrm{n}^{\circ} 17$, p. 3-52, $1^{\circ}$ sem. 1984.

RODRIGUES, C.; MONAGREDA, J.; PORTO, N. Estudos sobre raça, racismo e etnicidade na Ciência Política brasileira: uma análise do Campo a partir de seu estado da arte. Anais do 41 Encontro Anual da ANPOCS. 23 a 27 de outubro de 2017 - Caxambu, MG.

SANTOS, S. S; SANTOS, J. F. Reflexões a respeito das pesquisas desenvolvidas sobre temas raciais: a luz da política de cotas e da Lei 10.639/03 na Universidade Federal de Sergipe (UFS). Revista Convergência Crítica. Dossiê: Questão Racial, n. 8, 2016. THEODORO, M. A formação do mercado de trabalho e a questão racial no Brasil. In: THEODORO, M. (Org.); JACCOUD, L.; OSÓRIO, R.; SOARES, S. As políticas públicas e a desigualdade racial no Brasil: 120 anos após a abolição. Brasília: IPEA, 2008. p. 15-44. UNIVERSIDADE FEDERAL DE JUIZ DE FORA. Programa de Pós-Graduação em Ciência da Religião. Disponível em http://www.ufjf.br/ppcir/ Acesso em 20/04/2018. UNIVERSIDADE FEDERAL DE JUIZ DE FORA. Pró-Reitoria de Pós-Graduação e Pesquisa. Disponível em http://www.ufjf.br/propp/pos-graduacao/cursos/stricto-sensu/ Acesso em 20/04/2018.

UNIVERSIDADE FEDERAL DE JUIZ DE FORA. Site da Universidade Federal de Juiz de Fora. Notícias: Campanha da UFJF viraliza nas redes sociais em 04/02/2016. Disponível em http://www.ufjf.br/noticias/2016/02/04/campanha-da-ufjf-viraliza-nas-redes-sociais/ Acesso em 20/04/2018. 


\title{
Trajetórias de resistência de mães de santo e yalorixás
}

\author{
Resistance trajectories of mothers of saint and yalorixás
}

\author{
Gilmara Santos Mariosa ${ }^{6}$ \\ gilmaramariosa@gmail.com \\ Claudia Mayorga ${ }^{7}$ \\ mayorga.claudia@gmail.com
}

Resumo: Este trabalho trata de um recorte de uma pesquisa de doutorado em Psicologia Social em andamento na Universidade Federal de Minas Gerais que trata do Candomblé como um espaço de poder de mulheres negras. Aqui, damos ênfase a três mulheres negras precursoras de religiões de matriz africana em três regiões do Brasil, Iyá Nassô na Bahia, Na Agontimé no Maranhão e Tia Ciata no Rio de Janeiro Da maioria das religiões praticadas no Brasil, as religiões de origem africana estão entre as poucas nas quais as mulheres negras ocupam espaços de poder e não são limitadas em suas ações no sacerdócio em relação aos homens.

Palavras chave: mulheres negras; religiões afro; poder.

Abstract:This paper is about a review of a doctoral research in Social Psychology in progress at the Federal University of Minas Gerais that treats Candomblé as a power space for black women. Here, we emphasize three black women who are precursors of religions of African origin in three regions of Brazil, Iyá Nassô in Bahia, Na Agontimé in Maranhão and Tia Ciata in Rio de Janeiro. Most religions practiced in Brazil, religions of African origin are among the few in which black women occupy spaces of power and are not limited in their actions in the priesthood toward men.

Kay words: black women; afro religions; power.

\section{Introdução}

Da maioria das religiões praticadas no Brasil, as religiões de origem africana estão entre as poucas em que as mulheres negras ocupam espaços de poder e não são limitadas em suas ações no sacerdócio em relação aos homens. As mulheres nestas religiões são extremamente valorizadas e respeitadas, não sendo relegadas a posições inferiores. Ao contrário ocupam posições de destaque a tal ponto que estão entre as figuras de maior popularidade nestas práticas religiosas. Porém tem que lidar com o racismo, o sexismo e a intolerância religiosa.

Ao observar os espaços ocupados por tais mulheres no trabalho, na vida social, política e cultural, percebemos que as mulheres africanas ao contrário das europeias se

\footnotetext{
${ }^{6}$ Doutoranda em Psicologia Social pela Universidade Federal de Minas Gerais.

7 Professora do Departamento de Psicologia da Universidade Federal de Minas Gerais e do Programa de Pósgraduação em Psicologia.
} 
destacavam e tinham seu lugar social bem demarcado. $\mathrm{Na}$ sociedade brasileira, podemos perceber o quanto suas trajetórias são de destaque, protagonismo e liderança. Especialmente na religiosidade, nosso ponto de enfoque nesse artigo.

Vivemos em uma sociedade marcada pela desigualdade de gênero, raça e classe, na qual as mulheres são discriminadas e ocupam posições subalternas. Quando falamos de mulheres negras na sociedade brasileira a situação se acirra. Pois a maioria aglutina esses três atributos, ser negra, ser mulher e ser pobre.

Analisar os lugares e posições ocupadas pelas mulheres negras no cotidiano do candomblé pode nos auxiliar a melhor compreender os tensionamentos existentes no encontro entre a herança africana $\mathrm{e}$ as assimetrias das sociedades patriarcais contemporâneas. Assim como o legado diferenciado de que essas mulheres negras, de dentro do candomblé, vem construindo e passando às suas descendentes ao longo dos séculos.

Este artigo trata de um recorte de minha pesquisa de doutorado, enfatizando três mulheres negras precursoras de religiões de matriz africana em três regiões do Brasil Iyá Nassô na Bahia, Na Agontimé no Maranhão e Tia Ciata no Rio de Janeiro. Trata-se de mulheres que deixaram suas marcas na história do povo africano e afro-brasileiro.

\section{As africanas}

As mulheres africanas, que chegaram ao Brasil escravizadas, eram muito diferentes em seus costumes e formas de vida. Isso ficou bem destacado nas formas que desenvolveram para sua sobrevivência. Aqui chegando desenvolveram-se com destaque no comércio de rua, costume oriundo das terras africanas nos quais as mulheres eram reconhecidas como grandes comerciantes e negociantes.

Em África, as mulheres já possuíam liberdade e comandavam em seus reinos, eram mestres nas artes militares, assim como líderes na política, na economia, no comércio e na religião. As sociedades matrifocais ou matrilineares proporcionaram a essas mulheres uma existência na qual eram referências para seu povo, sendo respeitadas em nações diversas. (CLARKE, 1984).

No Brasil essas mulheres demostraram força, capacidade de liderança e organização. Reconstruindo com seus semelhantes as práticas religiosas de seus ancestrais, perpetuando uma das marcas mais presentes dos africanos e africanas na cultura brasileira, a religiosidade. 


\title{
Na Agontimé e a Casa das Minas no Maranhão
}

De acordo Pierre Verger (1990), a rainha Na Agontimé era esposa do rei Agonglo, do Daomé, atual Benin. O rei tinha dois filhos e designou que seu sucessor seria o filho mais novo, o príncipe Guezo. Porém por ele ainda não ter idade para assumir o trono, quando o rei veio a falecer, o príncipe Adandozan o filho mais velho deveria governar até que Guezo tivesse idade para tal.

Porém, contrariando a determinação do Rei Agonglo, Adandozan não só não passa o trono ao seu irmão, como realiza um reinado altamente sanguinário tendo, inclusive vendido como escrava a rainha $\mathrm{Na}$ Agontimé e vários membros da corte.

\begin{abstract}
Andandozan ficou como regente vinte e dois anos e Guezo teve que lhe arrancar o poder. Expulsou-o do trono, pois suas atrocidades e suas injustiças tinham enfastiado os daomeanos. Adandozan, que era filho de outra mulher de Agonglo, não tinha hesitado em vender aos mercadores de escravos da costa a mãe de Guezo e uma parte de sua família (Pierre Verger,1990, p. 153).
\end{abstract}

Após tomar o poder, o então Rei Guezo quis encontrar sua mãe, a rainha $\mathrm{Na}$ Agontimé. Enviou, então, os mais devotados e inteligentes homens do reino para buscá-la. Partiram então percorrendo os países da América para o qual eram mandados os cativos do Daomé. Contudo não obtiveram êxito. Todavia, Pierre Verger ao ter contato com a "Casa das Minas”, Casa de culto religioso de Matriz Africana de nação jeje, estabelecida no São Luíz do Maranhão, identificou que ali eram cultuados as mesmas divindades dos reis de Abomé. (Verger, 1990).

\begin{abstract}
A hipótese, a saber, que $\mathrm{Na}$ Agontimé teria traduzido o culto dos voduns reais de Abomé a São Luíz, foi recentemente reconhecida como sendo verossímel durante o "Colóquio sobre as sobrevivências das tradições africanas nas Caraíbas e na América Latina", que aconteceu em São Luís do Maranhão entre os dias 24 e 28 de junho de 1985 e cujo relatório final declara: "A Casa da Minas foi fundada em São Luís do Maranhão, no Brasil, pela rainha Na Agontimé, mãe do rei Guezo, condenada à deportação num acerto de contas no seio da família real, antes que seu filho ascendesse ao trono do Daomé em 1818".(Verger, 1990, 153, 154).
\end{abstract}

Giselle Cristina dos Anjos Santos (2011) relata que Na Agontimé no Brasil recebera o nome de Maria Jesuína. Conforme a autora ela conquistou sua alforria e organizou o culto aos voduns, que são os ancestrais divinizados da família real do Daomé. A Casa das Minas no Maranhão foi fundada em 1840. Sendo o culto praticado até os dias atuais. O nome da casa, de acordo com Jarrid Arraes (2017) é "Querebentã de Zomanudu” a "Casa das Minas”. 
De acordo com Mundicarmo Ferretti (2007), a Casa das Minas no Maranhão se caracteriza por ser matriarcal, na qual os cargos de maior poder são exercidos pelas mulheres, tal como em outros cultos de matriz africana no Brasil.

A rainha $\mathrm{Na}$ Agontimé apesar de separada de sua família e de seu reino não esqueceu seus costumes nem suas raízes. Reconstruiu seu culto em terras brasileiras. (Santos, 2011).

$\mathrm{Na}$ Agontimé reforça a característica de liderança feminina religiosa própria das mulheres africanas e afro-brasileiras. Destacando-se como fundadora de uma das casas religiosas mais tradicionais do Brasil.

\section{Iyá Nassô e o "Ilê Axé Iyá Nassô"}

Monique Augras (1983) assinala que a primeira casa de candomblé, que se tem notícia foi fundada na primeira metade do século XIX por mulheres africanas. A autora ressalta que elas nasceram em solo urbano. O primeiro grande templo foi fundado no centro de Salvador, ao lado da Igreja da Barroquinha. Silva (1994) faz um relato sobre as mulheres originárias da cidade de Keto, antigas escravas libertas, pertencentes à Irmandade de Nossa Senhora da Boa Morte, da Igreja da Barroquinha, exclusivamente de mulheres de origem nagô, que teriam fundado o terreiro de Candomblé chamado "Iyá Omí Asé Aira Intilé”. Este, logo depois, tomaria o nome de "Ilê Axé Iyá Nassô" e seria transferido para o subúrbio do Engenho Velho, passando a ser conhecido como Casa Branca.

Na primeira metade do século XIX, chegam a Salvador três mulheres e um homem de origem africana do Golfo do Benin. Iyá Detá, Iyá Kalá e Iyá Nassô e o Bamboxê Obitikó fundaram a primeira Casa de Candomblé do Brasil, a localização era próxima a Igreja da Boa Morte, no bairro da Barroquinha. O cargo de liderança religiosa da Casa foi designado a Iyá Nassô. (Gomes 2012, Moura 1995).

O terreiro posteriormente passa a se localizar em definitivo no bairro do Engenho Velho, ficando então conhecido como "Casa Branca Engenho Velho”. Depois da morte de Iyá Nassô, a sua sucessão causou uma cisão resultando na criação de outras casas com a mesma raiz, o Iyá Omi Axé Iyá Massê, que fica conhecido com o nome de Gantois, nome do antigo proprietário do terreno no Rio Vermelho e o Axé Opô Afonjá. Até a data atual essas três casas são as mais tradicionais e se caracterizam por serem matriarcais, só as mulheres ocupam os cargos mais altos da hierarquia.(Moura, 1995).

O candomblé trazido por Iyá Nassô para o Brasil é, de uma forma, um culto novo, pois compensa as lacunas na cosmogonia nagô ocasionadas pela escravatura com 
uma nova organização ritual, incorporando num só terreiro os cultos das principais cidades iorubas, diversamente do que ocorria na África, onde eles se davam em templos separados. O terreiro toma a forma simbólica do próprio continente africano, os orixás das cidades com seus assentamentos no barracão, enquanto as entidades do céu aberto são cultuadas em sua mata. O próprio termo candomblé, só aqui teria o significado de culto, ou casa religiosa [...].(Moura, 1995, p. 25).

A participação de Iyá Nassô é fundamental para o Candomblé de Keto no Brasil, de origem iorubá. A partir de seu protagonismo essa forte e representativa raiz foi possível de ser consolidada com bases e fundamentos religiosos específicos que ela trouxe de África. Toda a organização do culto, sua permanência e sua raiz estão plantadas nas demais casas da mesma origem perpetuando hoje o Candomblé iorubá no Brasil.

\section{Tia Ciata, a baiana mais famosa do Rio de Janeiro}

Hilária Batista de Oliveira, a Tia Ciata, teria sido uma das mais importantes figuras do samba e do candomblé na cidade do Rio de Janeiro. Ela aparece em vários registros que relatam a origem do samba carioca, e também se tornou, importante figura na difusão do candomblé no Rio de Janeiro. nascida em Salvador em 1954, no dia de Santo Hilário, na adolescência foi iniciada no candomblé. Em 1876, aos 22 anos, vai para o Rio de Janeiro, estabelecendo-se na rua General Câmara, inicialmente. Em seguida, passa a viver na vizinhança de um dos líderes da colônia baiana no Rio, conhecido como Miguel Pequeno. (Moura, 1995).

\footnotetext{
A seu espírito forte, Ciata aliaria uma crescente sabedoria devida, um talento para a liderança e sólidos conhecimentosreligiosos e culinários. Doceira, começa a trabalhar em casa e a vender nas ruas, primeiro na Sete de Setembro e depois na Carioca, sempre paramentada com suas roupas de baiana preceituosa, que nunca mais abandonaria depois de uma certa idade. (Moura, 1995, p. 95).
}

Tia Ciata por seus conhecimentos religiosos e de práticas de cura, tratou do Presidente da República Wenceslau Brás, que possuía um eczema na perna que os médicos não conseguiram sanar. Ficando curado pelas mãos da baiana, o então presidente teria, por gratidão, empregado seu esposo no gabinete do chefe de polícia. Tal fato teria ajudado sua casa se tornar um centro de encontro de culturas afro brasileiras em uma época na qual tais costumes eram perseguidos pela polícia. Tia Ciata era, também quituteira, atividade com forte fundamento religioso, tendo sua presença documentada no livro de Debret "Viagem pitoresca e histórica ao Brasil”. (Moura, 1995). 
Depois de cumpridos os preceitos, com parte dos doces colocados no altar de acordo com o orixá homenageado no dia, a baiana ia para seus pontos de venda, com saia rodada, pano dacosta e turbante, ornamentada com seus fios de contas e pulseiras. Seu tabuleiro farto de bolos e manjares, cocadas e puxas, os nexos místicos determinando as cores e a qualidade. Na sexta-feira, por exemplo, dia de Oxalá, ele enfeitava de cocadas e manjares brancos. (Moura, 1995, p. 97).

Tia Ciata era filha de santo da Casa de João Alabá de Omulu, Candomblé de tradição nagô, tendo sido iniciada por Bamboxê Obiticô, um dos fundadores da primeira e mais tradicional casa de candomblé da Bahia, o Ilê Axé IyáNassô. Tia Ciata era, portanto, ligada a linhagem mais tradicional do candomblé iorubá de Salvador. (Moura, 1995).

\footnotetext{
Na casa de Alabá, no Rio de Janeiro, Hilária era a primeira, Iyá Kekerê, mãepequena, sucedendo Deolinda, responsável pelas obrigações das feitas no santo, pela instrução sobre as oferendas propiciatórias que cada um devia fazer à medida que avançasse no culto, influindo sobre as questões espirituais e materiais dos fiéis. Como Ebami, mais sete anos de feita, era também a Axogum da casa, a mão-defaca, ligada ao sacrifício dos animais. A mãe pequena é a auxiliar direta do pai ou da mãe-de-santo que lidera o candomblé no contato com as noviças, a quem prescreve os banhos rituais (principalmente quando o chefe, como Alabá, é homem) e dirige as iaôs, já iniciadas, nas danças dos orixás. [...] É sua força e ascendência no santo que seria o centro da presença de Hilária junto à comunidade, um peso de líder que se fortalece tanto na organização das jornadas de trabalho, como na preparação dos ranchos, embora ela nunca saísse neles. (Moura, 1995, p. 100).
}

Ciata era filha de Oxum, gostava muito de festas. Sempre celebrava as festas dos Orixás na sua residência na Praça Onze. Depois das celebrações começava o pagode. A polícia da época dava muita atenção às reuniões de negros. Especialmente o samba e candomblé eram perseguidos, tratados como organizações perigosas. Atividades que deveriam ser extintas para que os ex-escravos pudessem se submeter mais docilmente a uma sociedade hierarquizada. Quando as festas em sua casa ganharam fama, o papel de seu marido, funcionário público e ligado à polícia tem participação fundamental para que seu espaço estivesse livre das batidas policiais. Sua casa então se transforma em um local privilegiado de afirmação dos negros para trabalho, samba e candomblé. Sua casa era frequentada também por membros da alta sociedade, atraídos por seu comércio de roupas, culinária, pelo samba e por curiosidade de conhecer os "feiticeiros" africanos, como eram chamados na época os praticantes do culto africano. (Moura, 1995).

Tia Ciata tem fundamental participação, por sua influência na época, pela difusão do samba e do candomblé na cidade do Rio de Janeiro. Demonstrava não apenas liderança e 
carisma como capacidade de articulação diplomática, recebendo em sua casa desde negros pobres até brancos ricos e influentes.

\section{O sacerdócio feminino nas religiões de matriz africana}

Muitas são as diferenças de concepção entre as mulheres africanas (iorubás e bantos) e as europeias. Numa sociedade marcada pelo patriarcalismo observamos que a emergência e manutenção do candomblé se deram, principalmente, na mão das mulheres. Ruth Landes (2002), em pesquisa sobre a participação das mulheres no candomblé, na cidade de Salvador, afirmou que essas mulheres negras "Eram seres humanos bem desenvolvidos na época em que o feminismo levantava voz, pela primeira vez no Brasil.” (Landes, 2002, p. 87).

\footnotetext{
No terreiro de candomblé, os segmentos subalternizados da sociedade podem experimentar a possibilidade de ascensão social e de desenvolvimento em uma nova sociabilidade, metamorfoseando seus lugares de desvantagem social em posicionalidades de prestígio, geralmente ligadas à hierarquia religiosa. Nesse lugar, as mulheres, inclusive as negras pertencentes à classe social mais pauperizada, ocupam altos cargos, diferentemente do que se verifica em outras religiões. Corroborando esse dado, tem-se que, sobretudo nas casas religiosas mais tradicionais brasileiras a organização sociorreligiosa nesses espaços se estrutura a partir da lógica matrilinear, sendo a figura mais importante na hierarquia religiosa a mãe-de-santo ou Iyalorixá (iyá=mãe).(Silva, 2010, p. 131).
}

A participação da mulher negra tanto na estrutura familiar como na religiosa é fundamental para a sobrevivência de um legado de memória, tradição e identidade cultural da população afrodescendente no Brasil. (Silva, 2010).

Outro fator importante de ser ressaltado é em relação aos casamentos. Landes (2002) destacou em sua pesquisa que a maioria das sacerdotisas não era casada. Por não quererem abrir mão de sua liberdade e autonomia. "Crianças e homens são bem vindos para uma mulher do templo. São a sua família - e ela cuida deles com a mesma boa vontade com que cuida do seu deus. Em troca, exige liberdade para si”. (Landes, 2002, p. 201).

A Yalorixá Mãe Stella de Oxóssi do Ilê Axé Opô Afonjá declara que se iniciou no Candomblé na adolescência, por herança de sua avó. Posteriormente, formou-se em Enfermagem e se especializou em epidemiologia e foi trabalhar como visitadora sanitária. Declara que se casou, mas em seu relato citado abaixo percebemos o papel que o casamento tem em relação a sua religião. (A Cidade, 2005). 
Aí fui, depois deu essa maluquice eu casei,né, depois separei do esposo e fiquei vivendo na minha casa,[...] Eu conciliava, graças a Deus, muito bem o trabalho de enfermagem com o axé. (A Cidade, 2005).

Percebemos em seu depoimento dois fatores importantes. Primeiro ela declara como o casamento para essas sacerdotisas não tem, de forma alguma, uma importância maior que seu sacerdócio. Outro fator é o trabalho, quando ela declara que conciliava bem o trabalho com o axé, já demonstra uma autonomia e independência em um período da história na qual isso era pouco comum para as mulheres. (A Cidade, 2005).Tal como nos relata a antropóloga Josildethe Consorte:

\begin{abstract}
O fatos dos terreiros terem se tornado tão importantes tem profundamente a ver com essa independência conquistada pela mulher. Porque elas mesmas financiavam toda a sua iniciação e tudo que decorria das obrigações contraídas através dessa associação, a tal ponto que a própria relação dessas mulheres com o seus companheiros suas relações estáveis ou não elas eram subsumidas, elas ocupavam lugar secundário em sua vida porque o terreiro vinha primeiro, o terreiro era muito mais importante. (A Cidade, 2005).
\end{abstract}

Uma etapa da pesquisa de Landes (2002) é uma entrevista com a Yalorixá Mãe Menininha. A sacerdotisa tinha um companheiro, mas revelou que nunca se casou. A pesquisadora avalia que ela teria perdido muito, pois na legislação brasileira da época (ano de 1936) a mulher teria que se submeter inteiramente ao marido, fato totalmente incompatível para organização do Candomblé. Mãe Menininha também explica para a autora como ocorrem os processos de sucessão nos templos.

Minha falecida tia - tornou a tocar o chão - herdou o cargo da mãe dela, a grande Júlia - tocou de novo o chão - e Júlia fundou o templo depois de chegar ao Brasil. Primeiro serviu como sacerdotisa no Engenho Velho - mãe e filha serviam juntas [...]. Sabe como é na Europa minha senhora. Nós, as mães, somos como as casas reais, passamos o nosso cargo somente a pessoas da família, em geral a mulheres. (Landes, 2002, p. 127).

Percebe-se nestas mulheres não apenas uma responsabilidade religiosa com o cumprimento de seu dever, mas também um orgulho de serem quem são. Em relação ao seu terreiro elas demonstram estar conscientes da importância que tem. Por parte das yalorixás, nota-se uma postura de respeito e seriedade. Exercem sua autoridade sem necessidade de autoritarismo. Tem plena consciência de seu status hierárquico, cada qual exerce seu poder ao seu estilo. 
Mãe Beata de Yemonjá (2006), importante nome do candomblé do Rio de Janeiro, falecida recentemente, relata em sua fala a importância do interesse por conhecimento é maior que o interesse pelo casamento. Demostrando como para essas mulheres a sua tradição e a transmissão do conhecimento e da tradição é mais importante.

Comecei a namorar com aquele rapaz, mas ele era como um irmão. Hoje é meu amigo e temos quatro filhos. Nunca tive vontade de casar. Achava que era uma coisa banal. Eu gostava mesmo era de estudar. Tinha mania de fazer cursinho. Acho que escrevo mal, mas leio muito bem e tenho uma caligrafia muito bonita. Já fiz curso de teatro, sou cabelereira, costureira, sei pintar, bordar e trabalhar com cerâmica. Sou uma mulher de 67 anos, mas me sinto uma criança, porque quanto mais eu aprendo, mais quero aprender.

Recebo a força dos meus ancestrais, que viveram nos engenhos. Sou descendente de escravos e entendo o sofrimento que passaram. Hoje eu coloco meu corpo, minha alma e meu saber a serviço deles. Continuo lutando para criar as oportunidades que eles não tiveram. Hoje sou Beata de Yemonjá." (Mãe Beata de Yemonjá, 2006, p. 17).

Mãe Beata de Yemonjá (2008) também declara que se sente uma guerreira quilombola, pois como uma mulher do candomblé, ela é responsável por preservar e manter a tradição, a cultura e aspectos do pensar coletivo negro. Demostrando sua ciência a respeito de seu papel como protagonista e mantenedora dessa história e memória.

\section{Considerações Finais}

Apesar de na sociedade patriarcal as mulheres serem sempre relegadas a papéis secundários em sua maioria, observamos uma discrepância no que se trata de mulheres de origem africana. As mulheres mencionadas nesse artigo são figuras que se destacaram e protagonizaram importantes movimentos e instituições de preservação da história, memória cultura e tradição dos negros e negras no país.

Contudo existe um sistema que força invisibilização das trajetórias de negros e negras no país. Porém, apesar do não reconhecimento social e histórico elas transcenderam e protagonizaram tornando-se sujeitos de suas próprias histórias.

As mulheres negras, africanas e suas descendentes no Brasil, enfrentaram e enfrentam desafios cotidianos, barreiras sociais, políticas e econômicas produzidas pelo sexismo e pelo racismo. Nessa luta prosseguem abrindo caminho para as suas sucessoras, desenvolvendo estratégias de enfrentamento, sendo a preservação de suas tradições religiosas alguns de seus mais importantes legados. 


\section{Referências}

A CIDADE das mulheres. Direção Lázaro Faria. Produção: Lázaro Faria. Participação: Mãe

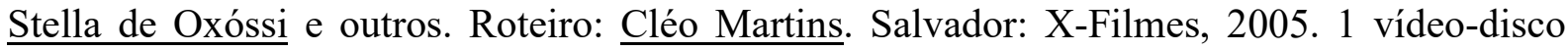
NTSC: son., color.(78 min.).

ARRAES, Jarrid. Heroínas negras brasileiras: em 15 cordéis. São Paulo: Pólen, 2017.

AUGRAS, Monique. O Duplo e a Metamorfose: a identidade mítica em comunidades nagô. Petrópolis: Vozes, 1983.

CLARKE, Jhon .Henrik. (1984) Rainhas Guerreiras Africanas. (Romio, J. trad) Texto original: -African Warrior Queens by John Henrik Clarke. In Sertima, Ivan Van (ed.) Black women in Antiquity. 1984.

FERRETTI, Mundicarmo. Matriarcado em terreiros de Mina do Maranhão - realidade ou ilusão? Revista Ciências Humanas: Dossiê Religião e religiosidade. V.5, $\mathrm{n}^{\circ} 1$, jul./dez. 2005, p.11-20.

GOMES, Elaine Cristina Marcelina. Mãe Regina de Bamboxê: diálogos entre Rio de Janeiro e Salvador, uma história social do axé. Dissertação (Mestrado em História) Programa de Pós-Graduação em História, Universidade Salgado de Oliveira. Niterói, p. 151. 2012.

LANDES, Ruth. A cidade das mulheres. Rio de janeiro: Editora UFRJ, 2002.

MOURA, Roberto. Tia Ciata e a Pequena África no Rio de Janeiro. Rio de Janeiro: Secretaria Municipal de Cultura, Departamento Geral de Documentação e Informação Cultural, Divisão de Editoração, 1995.

SANTOS, Giselle Cristina dos Anjos. Somos Todas Rainhas. São Paulo: Associação Frida Kahlo e Articulação Política de Juventudes Negras, 2011.

SILVA, Vagner Gonçalves da. Candomblé e Umbanda. São Paulo: Ática, 1994.

VERGER, P. Uma rainha africana mãe de santo em São Luís. Revista USP, n. 6, 30 ago. 1990, p. 151-158.

YEMONJÁ, Mãe Beata de. Primeiras palavras. In: NASCIMENTO, Elisa Larkin. (org.) Guerreiras da natureza: mulher negra, religiosidade e ambiente. São Paulo: Selo Negro, 2008. p. 21-22

YEMONJÁ, Mãe Beata de. Tradição e religiosidade. In: Werneck, Jurema; Mendonça, Maisa; White, Evelyn C. (orgs) O livro da saúde das mulheres negras: nossos passos vem de longe. Rio de Janeiro: Pallas/Criola, 2006. p. 16-19. 


\title{
Casas de axé: resistências e humanos direitos nos candomblés
}

\author{
Houses of axé: resistances and human rights in candomblés
}

\author{
Anderson Rodrigues Teixeira ${ }^{8}$ \\ anguian@hotmail.com
}

\begin{abstract}
Resumo: Esta comunicação propõe uma breve reflexão socioantropológica a respeito da estrutura, dos sentidos e da dinâmica social dos templos de candomblé - identificados frequentemente pela expressão êmica casas de axé. A proposta deste trabalho é destacar as formas criativas e protagonistas de resistência forjadas pelos africanos e afrodescendentes nas comunidades litúrgicas de Matriz Africana no Brasil. A partir de um intenso trabalho de campo desenvolvido nos terreiros de candomblé do Rio de Janeiro desde 2012, analiso a relevância do uso da categoria "casa" entre os fiéis no cotidiano sócio-religioso dos templos de candomblé. Nesta pesquisa, a casa de axé emerge como um território de resistência, que desde sua formação no século XIX, garante e resgata uma existência mais plena aos atores sociais que a compõem.
\end{abstract}

Palavras-chave: candomblé; casas de axé; terreiros; resistência; direitos humanos.

Abstract: This communication proposes a brief socio-anthropological reflection on the structure, the senses and social dynamics of candomble temples - often identified by the term houses of axé. The purpose of this work is to highlight the creative and protagonist forms of resistance forged by Africans and Afro-descendants in the African Matrices liturgical communities in Brazil. From an intense fieldwork developed in the candomble temples of Rio de Janeiro since 2012, I analyze the relevance of the use of the category "house" among the faithful in the socio-religious daily life of the candomble temples. In this research, the house of axé emerges as a territory of resistance, which since its formation in the $19^{\text {th }}$ century, guarantees and rescues a fuller existence to the social actors that compose it.

Key words: candomblé; houses of axé; terreiros; resistance; human rights.

Não há memória coletiva que não se desenvolva em um quadro espacial. (Halbwachs, apud Barros, 2010, p. 27) A perspectiva africana do terreiro, ao contrário, não surgia para excluir os parceiros do jogo (brancos, mestiços, etc.) nem para rejeitar a paisagem local, mas para permitir a prática de uma cosmovisão exilada.

(Muniz Sodré, 1988, p. 54)

Certo dia, durante meu trabalho de campo no Mercadão de Madureira $(\mathrm{RJ})^{9}$, fui surpreendido com um questionamento de meu assistente de pesquisa, que ao ser apresentado

\footnotetext{
${ }^{8}$ Doutorando em Ciências Sociais (PPGCIS/PUC-Rio); Mestre em Ciências Sociais (PPGCIS/ PUC-Rio); Especialista em Ciências da Religião (FSB-RJ) e História e Cultura Afrodescendente (PPGCIS/ PUC-Rio); Graduado em Letras (UNESA-RJ) e Interpretação Cênica (UNESA-RJ).

${ }^{9}$ O Mercadão de Madureira é um dos maiores mercados populares do país, sendo o principal centro distribuidor de artefatos votivos das religiões de Matrizes Africanas, no Rio de Janeiro. Em 2013, ele foi reconhecido como patrimônio cultural do estado. Centenas de religiosos deste segmento, oriundos de vários estados, frequentam diariamente o local para a compra de artefatos rituais de diversas procedências (países da África, Europa etc.). Parte de minha tese de doutoramento está imbricada ao que chamo de "circuito sagrado" afro-brasileiro no referido mercado.
} 
aos inúmeros elementos votivos expostos à venda no local, observou em minha verborrágica exegese o uso insistente da expressão "na minha casa". Em diversos momentos de nosso trabalho de pesquisa, eu apresentava os múltiplos usos litúrgicos de alguns materiais ali expostos, destacando como exemplo minhas próprias práticas em meu terreiro.

Sendo um homem de axé pesquisador, é bastante corrente a articulação de minhas experiências pessoais com a diversidade e complexidade que compõem o escopo de minhas pesquisas acadêmicas. $\mathrm{O}$ estudo das chamadas religiões de Matrizes Africanas - como percebo ser a identificação preferencial dos fiéis cariocas - não pode deixar jamais de considerar a rica multiplicidade dos fenômenos religiosos que se adequam sob esta terminologia geral. Mesmo os sistemas classificatórios criados pelos religiosos deste segmento, não encerram identidades "puras" e/ou "engessadas" de suas práticas sócioreligiosas. No conjunto destes saberes e práticas, que analiso como cientista social, vez ou outra, acabo enunciando algumas experiências de minha própria trajetória sacerdotal. Por isso, ao introduzir meu assistente de pesquisa no universo das compras votivas do povo de santo ${ }^{10}$, muitas vezes utilizei algumas dessas vivências pessoais como um dos contrapontos de um quadro mais amplo e múltiplo de práticas litúrgicas exercidas nos terreiros da cidade, abastecidos materialmente pelo mercado especializado.

Entrementes, o que nos interessa verdadeiramente neste preâmbulo, é o fato de meu assistente ${ }^{11}$ ter percebido com estranhamento o uso do termo "casa" toda vez que me referia aos templos religiosos de candomblé. De fato, esta não foi a primeira vez que atentei para a relevância de uma reflexão mais filigranar a respeito da categoria "casa", amplamente difundida na comunicação entre os candomblecistas. Desde minha reinserção ao ambiente acadêmico em 2012, nas inúmeras oportunidades que tenho de falar sobre o tema, por diversas vezes surgem pessoas com a mesma curiosidade a respeito de tal uso terminológico. O que para meu trabalho intelectual afigura-se como uma instigante possibilidade de reivindicação epistemológica, no tocante aos termos utilizados para pensar e analisar a realidade sócio-religiosa dos templos de candomblé.

Portanto, uma confluência de fatores me levou a discutir e escrever sobre este tema neste momento. Primeiramente, a curiosidade de meus interlocutores dentro da academia, que me sinalizaram a necessidade de desnaturalizar o uso da expressão. Minha

\footnotetext{
${ }^{10}$ Expressão bastante difundida para se referir ao conjunto de religiosos de Matrizes Africanas, sejam umbandistas ou candomblecistas.

${ }^{11}$ Pedro é um estudante de graduação em Ciências Sociais (PUC-Rio), que em sua trajetória pessoal teve contato religioso apenas com o cristianismo e o espiritismo. Nesta ocasião, era a primeira vez em que ele visitava um mercado especializado na venda de artefatos votivos de Matrizes Africanas.
} 
aposta inicial é de que ao desnaturalizar e problematizar o uso do termo no cotidiano do povo de santo, poderíamos apreender camadas semânticas mais subterrâneas no intuito de compreender a realidade social vivida pelas coletividades em questão. Além do que, tal empreitada intelectual colabora para uma reivindicação epistemológica que considere com maior acuidade as noções de religião e, consequentemente, de templo religioso próprias destes atores sociais.

Em segundo lugar, outro fator que instigou-me a refletir sobre as casas de axé foi o constante recrudescimento do racismo religioso por meio de ataques aos templos de todo o país. Pesquisas recentes (Fonseca \& Giacomini, 2013; Santos et al., 2016) demonstram, que para além das agressões verbais sofridas por religiosos nos espaços públicos da cidade, há um crescente número de ataques de ódio aos terreiros, com pichações, apedrejamentos, invasões destrutivas e vexatórias. O que deflagra ser o espaço de culto de Matriz Africana um alvo recorrente de intolerância, discriminação e violência na cidade:

[no mapeamento de terreiros da PUC-Rio/ 2013] Cerca de 75\% das ações de intolerância que não ocorreram em locais públicos tiveram a casa de culto como alvo. Dessa forma, seja por apedrejamento, invasão, destruição de imagens de culto ou pichação da fachada, acusação de venda de tóxicos ou de manter menores em cárcere privado, ameaça de expulsão ou perseguição de proprietário do imóvel, assim como por ser xingada e mal falada, a casa de culto geralmente está longe de gozar de uma rotina tranquila. (Giacomini, 2013, p. 144)

Ainda no contexto do mapeamento das 847 casas de axé no Rio de Janeiro realizado pela PUC-Rio, Giacomini (2013) afirma que entre os 430 templos que declararam sofrer atos de discriminação, a maioria dos casos ocorre em locais públicos (mais de $57 \%$ das ocorrências informadas). Entretanto, a autora salienta a enorme e significativa relação de proximidade entre as ruas em que os atos violentos ocorrem e a localização dos templos. Para a antropóloga, este mapeamento demonstra que "parece haver mesmo uma ordem crescente de incidência dos casos relatados conforme se esteja mais próximo da casa religiosa, que constitui como que um centro em torno do qual estão dispostas as ações relatadas". (Giacomini, 2013, p. 141)

Contudo, neste cenário de violência social no qual as casas de axé parecem continuar sofrendo um estigma histórico que visa seu aniquilamento da paisagem da cidade, optei por direcionar minha análise para o interior dos terreiros, tentando desvendar em seu cotidiano as formas de (re)existência e sociabilidade que parecem compor uma espécie de "ameaça" às estruturas circundantes. Por isso, nesta breve reflexão, não seguirei o percurso da violência despejada sobre os templos, mas antes sim, o caráter "subversivo" que as casas de 
axé - com suas solidariedades, afirmações identitárias e produção ritual da alegria deflagram desde seus primórdios, configurando-se como territórios de resistência criativa da cultura afrodescendente. É neste local, que as coletividades que partilham de uma cosmovisão afrocentrada, mas também de uma possível subalternização das próprias subjetividades e atividades, podem engendrar um inigualável potencial social:

\begin{abstract}
As comunidades litúrgicas conhecidas no Brasil como terreiros de culto constituem exemplo notável de suporte territorial para a continuidade da cultura do antigo escravo em face dos estratagemas simbólicos do senhor, daquele que pretende controlar o espaço da cidade. Tanto para os indígenas como para os negros vinculados às antigas cosmogonias africanas, a questão do espaço é crucial na sociedade brasileira [...]. Mas essa não é uma questão exclusiva de determinados segmentos étnicos. Para todo e qualquer indivíduo da chamada "periferia colonizada" do mundo, a redefinição da cidade passa necessariamente pelo remanejamento do espaço territorial em todo o alcance dessa expressão. (Sodré, 1988 , p. 18; grifos do autor)
\end{abstract}

No rastro desta dimensão sociológica das casas de axé na cidade, inclino-me novamente para as práticas cotidianas dos adeptos do candomblé. Aqueles que convivem intensamente neste universo sócio-religioso presenciam inúmeros usos discursivos, em que a categoria "casa" surge como elemento central. São muitas as atividades que estes sujeitos desempenham no seu dia-a-dia tendo sua noção idiossincrática de templo ("casa") como referencial. Expressões como: "abrir casa", "ter casa aberta", "na minha casa", "cada casa é um caso", "um toque 12 lá em casa", "encontrar uma casa”, "escolher uma casa”, "fundar uma casa" etc., são pistas eloquentes de uma noção muito própria tanto da vida religiosa, quanto do espaço de culto.

Em minha pesquisa de mestrado ${ }^{13}$, na qual estudei os abiãs do candomblé, ou seja, aqueles aspirantes à iniciação ritual, percebei com muita frequência a força da categoria "casa" nas maneiras de viver no candomblé. Embora a literatura especializada não se debruce com maior fôlego sobre este primeiro status do rígido sistema hierárquico do candomblé, é nesta primeira etapa da vida ritual que o candomblecista apresenta sinais claros da noção bem particular que se tem nesta religião a respeito do templo de culto.

Ao contrário do que superficialmente explicam alguns, o abiã não é aquele religioso "sem casa", como costumeiramente se escuta falar. Estes postulantes possuem vínculos morais incipientes com uma casa de axé específica, ocupando por um período

\footnotetext{
${ }^{12}$ Usa-se a expressão "toque" como referência aos dias de festividade pública nos terreiros. O termo faz alusão ao toque dos tambores que embalam os cânticos votivos imprescindíveis aos rituais.

${ }^{13}$ Em março de 2017, defendi a dissertação "O abiã é o começo, o pé da história": performances do noviciado no(s) candomblé(s). (PPGCIS/ PUC-Rio)
} 
variável e indeterminado, uma condição liminar na família ritual. A qualquer momento pode oficializar seus laços de parentesco ritual através da reclusão iniciática, ou contrariamente, abandonar o grupo de vez. Nesta fase, que alguns religiosos traduzem como um "namoro mútuo entre o abiã e a casa de axé", o iniciando está desfrutando da força sagrada e dos ensinamentos primários da vida no santo ${ }^{14}$.

No estudo desta categoria específica de religiosos, identifiquei o papel crucial que a casa de axé exerce sobre seus frequentadores. Na perspectiva de meus interlocutores, a casa aparece sempre como um agente vivo capaz de modular as potências místicas que compõem as próprias pessoas. São inúmeras as descrições de como a visitação aos terreiros em momentos de festividade pública ou não, interferem no desabrochar da espiritualidade dos indivíduos. Já presenciei muitos daqueles que recorrem às consultas oraculares nas casas de axé, descreverem que a breve estadia nestes espaços por algumas horas já foi suficiente, para um apaziguamento energético ou psíquico de seus inúmeros desequilíbrios. Da mesma forma, os abiãs descrevem um verdadeiro périplo para encontrar "a casa certa", aquela na qual as potências cósmicas (orixás) apontem como a possibilidade acertada para a iniciação.

De fato, as práticas rituais desenvolvidas nestas comunidades litúrgicas apontam para a noção de um espaço sagrado muito mais autônomo do que nas religiões cristãs, por exemplo. No caso do candomblé, a casa de santo ${ }^{15}$ não é apenas habitada pelas forças cósmicas, os seres espirituais, visto que ela mesma constitui uma entidade viva, que interage cotidianamente com seus habitantes. Esta tipologia de comunidade litúrgica é fundada numa outra noção basilar, a saber: o axé, isto é, a força dinâmica sem a qual não há nenhuma forma de existência. (cf. Sodré, 1988; Santos, 2002, Barros, 2010) Como afirma Bastide, "o candomblé não se torna lugar de culto senão depois de consagrado, e a consagração consiste em enterrar os axés. [...] Não há candomblé sem axé”. (2001, p. 77) Por conseguinte, a casa de culto é uma fonte irradiadora de axé, já que:

É a força que assegura a existência dinâmica, que permite o acontecer e o devir. [...] A força invisível, a força mágico-sagrada de toda divindade, de todo ser animado, de toda coisa. [...] Todo objeto, ser ou lugar consagrado só o é através da aquisição de àse [axé]. Compreende-se assim que o "terreiro", todos os seus conteúdos materiais e seus iniciados, devem receber àse, acumulá-lo, mantê-lo e desenvolvê-lo. Para que o "terreiro' possa ser e preencher suas funções, deve receber àse. O àse é "plantado" e em seguida transmitido a todos os elementos que integram o "terreiro". (Santos, 2002, p. 39; grifos da autora)

14 Expressão muito usual entre os religiosos, para indicar o estilo de vida daqueles que fazem parte do candomblé.

${ }^{15}$ Outra versão difundida entre os religiosos para a expressão casa de axé. 
Neste ínterim, cabe uma breve consideração quanto à formação e estruturação arquitetural e simbólica desses templos. Farta literatura especializada (Bastide, 1973, 2001; Santos, 2002; Sodré, 1988 etc.) já registrou que a estrutura ritual e arquitetônica dos candomblés é uma atualização em solo brasileiro de diversas tipologias de cultos em África. $\mathrm{O}$ advento da diáspora forçada de milhões de africanos por mais de três séculos teve como consequência imprevista o desenvolvimento de formas culturais bastante originais, que em certa medida possibilitaram aos exilados africanos certo resgate simbólico de suas pertenças originais.

É neste contexto histórico, que as diversas nações étnicas africanas acabam dando origem a uma rica tipologia de cultos de Matriz Africana no Brasil. Os cultos que eram devotados às divindades protetoras de clãs e suas linhagens transformaram-se em templos de adoração de um amplo panteão de divindades. Assim, africanos e afrodescendentes de origens étnicas diversas reuniram-se numa mesma "sociedade de auxílio mútuo". (cf. Bastide, 2001, p. 111) A noção de nações étnicas originou as nações rituais, como forma de classificação identitária das diversas práticas litúrgicas desenvolvidas em solo brasileiro ${ }^{16}$. Porém, à parte as especificidades rituais de cada uma delas, o princípio fundante subjacente é o mesmo, sendo a casa de axé:

[...] o lugar da memória, das origens e das tradições, onde, além de se preservar uma língua ancestral, na qual são entoados os cantos e as louvações, se celebra a vida de uma maneira muito particular, isto é, daqueles que decidiram, juntos, vivenciar uma visão de mundo comum, com regras específicas de convivência, baseadas no parentesco mítico, no princípio de senioridade e na iniciação religiosa. (Barros, 2010, p. 31)

Dito isto, compreende-se a existência de uma tipologia estrutural comum às diversas casas de candomblé, independentemente de sua "identidade étnica/ritual". Como observou Bastide $(1973 ; 2001)$, as casas de axé parecem reproduzir simbolicamente a África ancestral da qual os africanos foram exilados. Obviamente, as condições materiais de cada grupo de culto irão modular a configuração dos respectivos terreiros, mas sempre respeitando os padrões gerais que permitem ao santuário ser uma imagem reduzida das origens perdidas na travessia atlântica. De maneira geral, em todos os templos separam-se os altares de

\footnotetext{
${ }^{16}$ De maneira geral, o candomblé está subdividido nas seguintes nações: jeje, queto, efon e banto. Porém, a presença das diversas culturas africanas em diferentes partes do Brasil deu origem também a outras tipologias religiosas de Matriz Africana, tais como: terecô, xangô, tambor de mina, jurema, jarê etc. Cada vez mais percebemos que as fronteiras geográficas tornam-se porosas, impossibilitando uma correlação rígida destas modalidades religiosas e suas regiões de culto.
} 
devoção de cada divindade, de acordo com suas proximidades ou distanciamentos nos cultos originais africanos. Dependendo das extensões mobiliárias de cada casa de axé, tais separações podem ocorrer: a) em forma de pequenas "casas" isoladas e distribuídas na propriedade, b) como pequenos "quartos", ou mesmo, c) dentro de um único cômodo com diferentes prateleiras para cada devoção. Como também salientou Bastide $(1973,2001)$ o traço arquitetural dos terreiros obedece mais às funções rituais do que às funções arquitetônicas. Por este motivo, tudo que é estrutural está imerso num sentido cosmológico capaz de produzir a eficácia esperada pela elaborada vida litúrgica.

Ainda no tocante as especificidades da vida sócio-religiosa das casas de axé, pode-se destacar uma intensificação da intimidade partilhada, pois os sujeitos passam longos períodos dormindo e convivendo com seus pares. A dimensão do íntimo e do privado tão típicos na considerada modernidade ocidental reduz-se sobremaneira. O terreiro propõe a todos os membros a execução constante de inúmeras tarefas conjuntas, tais como lavar, cozinhar, faxinar, engomar, banhar o outro etc. Muitos destes afazeres apresentam-se imbuídos do cuidado, pois são realizados para si e para os pares. Então, o espírito comunal e solidário é imperativo nas relações humanas que ali se dão, seja nos momentos propriamente rituais ou não.

Cabe destacar também, que a inserção no cotidiano das casas de axé é permeada por uma pedagogia multidisciplinar. A manutenção e o funcionamento da estrutura exige que inúmeras habilidades sejam desenvolvidas pelos fiéis. Dentre elas, podemos destacar a pintura, a culinária, a costura, o canto, a dança, a escultura em madeira ou argila, a botânica, o aprendizado de línguas africanas, noções de economia e administração etc. Além do que, há um estímulo constante de aprimoramento das experiências olfativas, sensoriais e gustativas.

Entrementes, o ponto fulcral que importa enfatizar a respeito da casa de axé, é sua capacidade fecunda de fomentar a sociabilidade, a solidariedade e a reversão da objetificação dos sujeitos numa realidade social opressora, violenta e profundamente assimétrica. Mesmo antes da formulação dos Direitos Humanos pela ONU (1948) ou da existência de uma Constituição Federal (1988), que garantissem aos indivíduos o direito a uma vida digna, os terreiros já figuravam no cenário social brasileiro como territórios de resgate e fomento de uma humanidade covardemente negada aos africanos e afrodescendentes. Embora o contexto social hoje apresente novas configurações, a função humanitária dessas comunidades litúrgicas permanece ativa. 
A casa de axé revela-se como território de resistência, não apenas por manterse firme e inabalável mediante forças adversas que tentam impedir-lhe a existência, mas ao contrário, por seu potencial criativo e socialmente ativo. O protagonismo dos povos de terreiro ao elaborarem formas originais de existir num mundo tão adverso, é prova cabal de que a colonialidade do poder e do saber eurocentradas não alienaram de forma absoluta os sujeitos por elas oprimidos.

A coesão social dessas coletividades afrodescendentes, o resgate e manutenção de repertórios culturais afrocentrados, e a produção mesma da alegria festiva que constitui seu ethos extrapolam o cerco coercitivo das culturas dominantes que negam sua singularidade e riqueza culturais:

\footnotetext{
A partir do terreiro, território de um jogo cósmico, o axé dos escravos e seus descendentes mostra os limites ao poder do senhor: graças à força da alacridade, resiste-se à pressão degradante dos escravizamentos de qualquer ordem e institui-se um lugar forte de soberania e identidade. (Sodré, 1988, p. 149)
}

Enfim, seria válido tomar estas considerações introdutórias como um estímulo para novas formulações epistemológicas, que permitam uma compreensão mais apropriada das idiossincrasias que constituem as sociabilidades e religiosidades dos povos de Matrizes Africanas na sociedade brasileira.

\section{Referências Bibliográficas}

BARROS, José Flávio Pessoa de. Na minha casa: preces aos orixás e ancestrais. Rio de Janeiro: Pallas, 2010.

BASTIDE, Roger. Estudos afro-brasileiros. São Paulo: Editora Perspectiva, 1973. . O candomblé da Bahia: rito nagô. São Paulo: Companhia das Letras 2001.

FONSECA, Denise Pini Rosalem; GIACOMINI, Sonia Maria. A presença do axé: mapeando terreiros no Rio de Janeiro. Rio de Janeiro: Ed. PUC-Rio, 2013.

SANTOS, Babalawô Ivanir... [et al.] (Organizadores). Intolerância religiosa no Brasil: relatório e balanço. Rio de Janeiro: Kline: CEAP, 2016.

SANTOS, Juana Elbein dos. Os nagô e a morte: pàde, àsèsè e o culto égun na Bahia.11.ed. Petrópolis: Vozes, 2002.

SODRÉ, Muniz. O terreiro e a cidade: a forma social negro-brasileira. Petrópolis: Vozes, 1988. 


\title{
Raça amaldiçoada? Diálogos sobre a formação de uma cultura negra evangélica fruto da diáspora
}

Damn race? Dialogues on the formation of a black evangelical culture fruit of the diaspora

\author{
Lavini Castro \\ lavinicastro@gmail.com ${ }^{17}$ \\ Mariana Gino \\ mariana.gino@gmail.com ${ }^{18}$
}

Resumo: O presente trabalho tem como objetivo apresentar os símbolos que representam a raça negra como estigmatizados, parte de um projeto de poder que vem se cristalizando desde a Era Moderna. Os grupos foram então, categorizados por hierarquias raciais bem como seus atributos culturais, no caso brasileira a cultura branca representa beleza, verdade, integridade, enquanto a cultura negra era desvalorizada representando o feio, errado, o ruim. Dessa forma não há outra versão para a cultura religiosa de matriz afro-brasileira a não ser representar aspectos do universo da demonização. Contudo, mesmo nesse contexto negativo para o ser negro, há maneiras desse sujeito expressar sua negritude e interferir na realidade sociocultural.

Palavras-chave: Demonização, Negritude, Cultura, Identidade

Abstract: The present work aims to present the symbols that represent the black race as stigmatized, part of a project of power that has been crystallizing since the Modern Era. The groups were then categorized by racial hierarchies as well as their cultural attributes, in the Brazilian case the white culture represents beauty, truth, integrity, while black culture was devalued representing the ugly, the wrong, the bad. In this way there is no other version for the religious culture of Afro-Brazilian matrix than to represent aspects of the universe of demonization. However, even in this negative context for the black being, there are ways of this subject expressing his blackness and interfering in the socio-cultural reality.

Keywords: Demonization, Negritude, Culture, Identity

\section{O cenário da demonização da cultura afro-brasileira}

Os acontecimentos do século XVIII e XIX são interpretados a luz da ótica iluminista e racionalista em que cresceram discursos universalistas sobre os direitos dos indivíduos num contexto de formação de Estados Nacionais. Assim a ideia de nação ganha forte interesse político e intelectual nesse momento em que são pensadas as relações sociopolíticas e demarcadas estratégias de poder entre os grupos formadores da sociedade. Dentro deste

\footnotetext{
${ }^{17}$ Lavini Castro Mestranda em Relações Etnico Raciais pelo Programa de Pós-graduação em Relações Etnico Raciais do Cefet/RJ - PPRE.

${ }^{18}$ Mariana Gino, Doutoranda em História Comparada pela Universidade Federal do Rio de Janeiro - UFRJ.
} 
contexto a categoria de raça, que já era objeto de estudo desde o início da Era Moderna, ganhando diversos contornos conceituais, será conceituada, a partir do século XIX, de forma científica provocando interesses intelectuais que buscavam avaliar e classificar os grupos humanos por conta de suas características fenotípicas. Os estudos eram pautados na ideia de haver uma hierarquia racial entre os grupos humanos apesar das discussões liberais, que também estavam presentes no século XIX, mas parecem não ter representado um eco tão contraditório às narrativas racialistas desenvolvidas num sentido um tanto determinista.

Sabendo que o contexto histórico e científico do século XIX estabeleceu a categoria de raça como definidora de padrões estéticos, psicológicos e cognitivos produzindo um olhar hierárquico a respeito dos diferentes tipos humanos em que o elemento branco era visto como padrão a ser seguido. Dentro desta perspectiva o pensamento ocidental dominante ficou inclinado a considerar e a afirmar todas as culturas diferentes dos moldes europeus como inferiores, enquanto que se projetava o aval de propagação civilizatório branco para atender aos anseios mercadológicos europeus.

Não restam dúvidas ao pensar que as novatas "nações" latino-americanas, que ganhavam suas independências no século XIX, acabaram se baseando nos modelos políticos, econômicos, sociais e culturais dos ditames europeus como solução real para atingir ao progresso civilizatório. Porém projetava-se a razão do atraso econômico e tecnológico latinoamericano por conta de seus componentes raciais, ou seja, devido à maioria de seu composto social ser formado por descendentes indígenas e africanos as sociedades latino-americanas foram consideradas como improváveis constituidoras do progresso. $\mathrm{O}$ problema pautado nas discussões nacionalistas girava em torno da impossibilidade de se atingir ao tão famigerado progresso sem os elementos raciais condizentes, nesse caso o elemento branco.

No Brasil, uma sociedade mestiça e multicultural, o debate traçado em torno da realidade do atraso econômico trazia como pauta justificadora a presença negra enquanto inibidora do sucesso civilizatório. Portanto era preciso discutir a presença do negro no Brasil, pois havia necessidade de traçar o destino do povo brasileiro em vias de formação. O grande desafio era atingir ao progresso tendo o negro como parte desse processo. Dos autores que competem chamar atenção a cerca desse debate, escolhemos Fernando Ortiz (1973), Nina Rodrigues (1935), Roger Bastide (1971).

Nina Rodrigues e Fernando Ortiz, discutem o tema por um víeis racialista apesar de serem reconhecidos no meio acadêmico por desenvolverem propostas mais progressistas, fato este que permitiu novos olhares interpretativos, mas que ainda não se desvinculavam totalmente de um contexto determinista. Fernando Ortiz (1971) foi categórico em afirmar a 
influência do elemento negro, mas defendeu estratégias de branqueamento para salvar a nação (neste caso cubana), pois via atributos positivos na mestiçagem como caminho para a regeneração sociorracial. Ao contrário de Ortiz, Nina Rodrigues (1935), um médico baiano, era contundente em classificar o fracasso do elemento negro, tinha projetos eugenistas e recusava-se a aceitar a mestiçagem como solução civilizadora.

Numa outra linha de raciocínio, Roger Bastide (1935) investiga as religiões africanas numa perspectiva histórica visto que as representações africanas ao serem tiradas de seu lócus de ação com seus elementos formadores se renovam em outro lugar. Sendo assim Bastide sobrepõe o aspecto religioso sobre o social. Em outros termos, podemos pensar a articulação necessária dos afro-brasileiros em manter sua cultura existindo fora de África, a partir da resistência, da criatividade e da expansão cultural dos negros.

O pensamento desses autores servem para captar o contexto em que a sociedade brasileira foi formada, buscando compreender as bases que promoveram o discurso racista que influenciaram o pensamento religioso cristão em detrimento das religiões de matrizes africanas, entendidas como algo demoníaco em nossa sociedade e como os negros atuaram para não perderem seu espaço de atuação sociocultural.

Precisamos aceitar que diante da estrutura religiosa do Brasil, o cristianismo se formou como religião hegemônica imposta aos elementos étnicos não brancos de nossa sociedade enquanto passavam por processos de aculturação.

Como explicação mais plausível poderíamos sugerir que muitos afro-brasileiros, hoje pertencentes às religiões evangélicas, não se identificam com sua ancestral religião africana, porque historicamente a cultura cristã dominante usou do controle político e cultural para educar os dominados mantendo-os em submissão, porque era conveniente para a hegemonia cristã inibir a potencialidade transformadora das demais culturas.

Enquanto em nome da "nação" as classes dominantes criaram no povo um sentimento de identificação com elas, em nome da salvação cristã grande parte dos afro-brasileiros e indígenas perdeu identidade com suas culturas originárias. Desta maneira o que no passado foi hegemonia católico-jesuítica hoje vem se cristalizando como domínio evangélico fundamentalista, mas a exclusão das culturas de matriz afro-brasileira se mantém.

Embora, atualmente haja estudos que contemplem a agência dos negros em demarcar sua presença e de sua cultura no seio de nossa sociedade, como podemos identificar nas novas interpretações a respeito do sincretismo apresentadas por Ari Pedro Oro e José Carlos Gomes dos Anjos (2008), quando avaliam a crítica dos afro-brasileiros seguidores de religiões de matrizes africanas a respeito da perda de fundamento da cerimônia religiosa sobre a festa de 
Nossa Senhora dos Navegantes. O fato dos afro-brasileiros perceberem a desterritorialização da cultura afro no cotejo da festa é sinal da percepção da presença e interferência dos negros na sociedade, pois a saída de um referencial afro-brasileiro numa festa, a princípio lida como católica incomodou bastante os seguidores das religiões de matrizes africanas.

Outra contribuição do livro Festa de Nossa Senhora dos Navegantes / Sincretismo entre Maria e Iemanjá, foi à maneira como os autores Oro e Anjos conduziram a interpretação a respeito de como o pensamento afro-brasileiro se relaciona com as demais culturas, até porque de acordo com os autores, "após séculos de evangelização fíca difícil saber em que consiste o sistema original do pensamento africano, difícil saber se ainda existe um sistemapartida" (ORO \& ANJOS, 2009, pág 65).

Ou seja, pensar elementos diaspóricos, como é o caso dos sujeitos negros é admitir estratégias de sobrevivência que lançaram mão de negociações, interpretações, reinterpretações em que é possível numa festa tradicionalmente católica haja indivíduos das religiões de matrizes africanas, sem o menor constrangimento em dividir não só o espaço como a homenagem ao santo que ora pode ser a própria santa católica ora pode ser referência a Iemanjá.

A possibilidade está no fato do sujeito negro, ao longo de sua história fora de África, aprender a lidar com as adversidades, negociar sua presença, e conduzir seu pensamento muitas vezes por justaposição experimentando novas realidades existenciais, compondo novas maneiras de ler o mundo, sem que para isso, de acordo com o alerta de Oro e Anjos (2009), o sujeito negro deixe de permanecer ligado a sua cultura ancestral.

Difícil é identificar de que forma o negro evangélico, seguidor das práticas neopentecostais, se mantêm ligado a sua cultura ancestral, a medida que o proselitismo, de ordem neopentecostal, identifica na cultura africana os elementos demoníacos.

\section{Leituras Evangélicas a respeito da cultura afro-brasileira}

De acordo com Ricardo Mariano, ao mencionar Edir Macedo, a crença neopentecostal é categórica em afirmar que as religiões de matrizes africanas seriam "os principais canais de atuação dos demônios no território brasileiro" (MARIANO, 2015, pág. 133). Mais adiante Mariano nos apresenta dados estatísticos apresentados pelo Iser sobre a opinião dos evangélicos moradores do Grande Rio de Janeiro a respeito da umbanda e candomblé em que 95\% consideram como religiões demoníacas. 
Está no proselitismo cristão a luta do bem contra o mal e o destino da evangelização de todos os povos a partir das conversões primeiramente implantadas pelos apóstolos, mas seguida por estratégias Estatais na Era da Cristandade, posteriormente nas Cruzadas nas ações jesuíticas e tantas outras ações religiosas para impor o cristianismo como ideologia religiosa hegemônica.

A realidade de discriminação as religiões de matrizes africana é resultado do século XIX e as teorias racialistas que perduram até hoje no senso comum. Segundo Ricardo Mariano (2009, pág. 131) aos praticantes das religiões afro-brasileiras eram indicadas acusações de prática ilegal de medicina, curandeirismo e magia negra apresentadas na mídia, e processos judiciais. Uma série de alegações e informações midiáticas contribuíram para criar um imaginário sociocultural a respeito das religiões de matrizes africanas.

Tomando como base nosso contexto sócio-histórico e a realidade sectária das religiões cristãs é mais provável que não haja interesse da pessoa negra, que professe a fé evangélica, em reivindicar sua herança cultural afro-brasileira muito menos em respeitar a convivência religiosa de matriz africana. Porém de acordo com Morgane Laure Reinaa (2017) há indícios para pensarmos a formação de uma cultura negra evangélica.

Sendo o negro um elemento rejeitado socialmente precisamos considerar que sua cultura também foi rejeitada, não é a toa que o número de seguidores das religiões cristãs é a maioria da população comparado ao quantitativo de seguidores das religiões de matrizes afrobrasileira. De acordo com Vagner Gonçalves da Silva em seu artigo Entre a gira de fé Jesus de Nazaré (2015) as religiões afro-brasileiras não contabilizaram, pelos dados do IBGE, mais do que $1,7 \%$ ao passo que as religiões cristãs ultrapassam a estimativa dos $70 \%$. Outro resultado que podemos apresentar mostra-nos o crescimento do número de seguidores evangélicos negros aos cultos pentecostais. Segundo dados mais recentes do Instituto Brasileiro de Geografia e Estatística (IBGE), existem 11.951.347 negros evangélicos. Desses, $8.676 .997(72,6 \%)$ são pentecostais, enquanto a população negra de umbandistas e candomblecistas não alcança 253.000 pessoas.

A aproximação dos negros ao pentecostalismo e ao neopentecostalismo esbarra na desvalorização da cultura afro-brasileira. A fé de cunho pentecostal, mas principalmente a neopentecostal, atua como uma estratégia de aculturação ao negro impedindo a formação de um sentimento de pertencimento e de valorização da ancestral cultura afro-brasileira. Nesse sentido, concordamos com Kabengele Munanga (2012) em que pensar a construção da identidade como uma estratégia ideológica, no caso negro, é urgente para valorizar o passado do grupo negro e seus costumes permitindo não só a definição, mas o reconhecimento da 
diversidade cultural, a noção de participação política dos negros em sociedade além de reforçar a solidariedade e conservação histórica, assim como ampliar direitos ao próprio grupo. Entretanto o desafio é garantir espaço para a afirmação da negritude e resgate do valor histórico e cultural dos negros neopentecostais sabendo que sua liturgia se apresenta hostil aos elementos culturais afro-brasileiros ao ponto de demonizá-los.

A resposta para tal contracenso em ser negro e não valorizar o que nos faz negro, ou seja, ser um negro evangélico e não valorizar os elementos culturais negros, não há dúvidas, é o racismo, no plano de fundo desse artigo o racismo religioso. Todavia a questão que encoraja esse estudo é o fato de identificarmos negros evangélicos vinculados a causa da negritude. Sabemos que um dos motivos para a identificação negra às religiões neopentecostais está na capacidade dessas igrejas trabalharem a valorização da autoestima do fiel por meio de seu culto e liturgia. O elemento social negro está mais propenso a experimentar a pobreza uma categoria responsável por provocar uma baixa autoestima e, consequentemente, por conduzir a desvalorização pessoal do indivíduo, portanto percebemos que o pentecostalismo e neopentecostalismo acabam auxiliando nesse sentido. Ao se tratar do neopentecostalismo, principalmente, em que as experiências das mediações mágicas e o transe religioso não só configuraram apropriação do repertório afro-brasileiro como a promoção da experiência do avivamento foi uma estratégia para aproximação aos grupos culturais já acostumados com tais práticas, como bem coloca Vagner Gonçalves da Silva (2015):

$\mathrm{O}$ ataque às religiões afro-brasileiras, mais do que uma estratégia de proselitismo junto às populações de baixo nível socioeconômico, potencialmente consumidoras dos repertórios religiosos afro-brasileiros e neopentecostais, parece ser consequência do papel que as mediações mágicas e a experiência do transe religioso vieram a ocupar na própria dinâmica do sistema neopentecostal em contato com o repertório afro-brasileiro. (SILVA, 2015, pág. 193)

Dessa forma, as práticas mágicas e a incorporação mantinham o fiel dentro da filosofia litúrgica africana permitindo ao fiel se expressar dentro de seu entendimento cultural, permitindo projetar o sentimento de legitimidade de tais práticas negras pelo fato do avivamento ser conduzido dentro do pensamento religioso cristão que é hegemônico em nossa sociedade, além do discurso de consolo e sensação de comunidade.

Avaliando todo esse cenário, temos o interesse de perceber se, de fato, as estratégias de imposição cultural referendam o discurso sobre a total falta de noção de pertencimento dos negros a respeito de sua ancestralidade cultural, ou se é possível notarmos a existência de comportamentos subterfúgios, desses atores sociais, em resistir às imposições a partir de 
demarcações estéticas e socioculturais do elemento negro, mesmo que não totalmente conscientes de suas atitudes.

Justificamos nosso interesse no dilema da aculturação negra pela persistência dos valores culturais negros. De fato muitos negros demonstram hoje enorme rejeição a sua cultura ancestral, porém muitos ainda são articulados a ela; contudo percebemos um movimento de aproximação, principalmente no campo estético, do negro à suas raízes imagéticas afirmadas pela vestimenta e estilo de cabelo. Essas questões queremos elucidar.

Pretendemos entender o tipo negro que se afirma evangélico, seguidor da liturgia neopentecostal, para saber o quanto neste sujeito afirma-se sua negritude, pois notamos no seio neopentecostal atitudes de desaprovação direta aos diferentes elementos culturais do negro, especialmente às religiões de matrizes africanas. No entanto encontramos indícios para pensar o comportamento relacional, nada avesso, entre identidade evangélica neopentecostal e a identidade negra, quando a juventude negra evangélica tem se posicionado esteticamente as valores culturais afro-brasileiros. Nosso problema, portanto, é identificar como o elemento negro se afirma enquanto raça diante de uma liturgia que refuta a cultura negra.

Posto isto, mesmo num contexto hostil às religiões de matrizes africanas, que eram assimiladas como seitas, seus rituais eram tidos como inapropriados e as cerimônias classificadas como inferiores, permaneceram, dando condições para que muitos negros e mestiços pudessem rememorar sua história para criar algum vínculo cultural.

\section{O negro negociando sua negritude dentro do meio neopentecostal}

Nina Rodrigues em sua obra "O animismo fetichista dos negros baianos", apresenta um estudo sobre a possessão nos cultos candomblecistas afro-brasileiros. Segundo Lilia Moritz Schwarcz (2007, p. 882), Nina Rodrigues pretendia chegar à constatação de que a possessão seria um caso coletivo de histeria dos negros e dos povos mestiçados. A vista disto as celebrações e rituais eram um problema de natureza biológica, sendo o campo psicológico um bom meio para análises. Contudo seus estudos avançaram numa linha progressista que nem mesmo o mais experiente médico etnólogo deixou escapar a associação entre culturas ao dizer: "longe do negro se converter ao catolicismo, é o catolicismo quem vem recebendo a imensa influência do fetichismo e se adapta ao animismo" (Schwartcz, 2007, p. 882). Fica clara a dificuldade da imposição deixando brechas para se pensar um contexto mais relacional no que geralmente é identificado como uma imposição ou desencontro de culturas. 
Nesse sentido, por mais perverso que fosse o contexto colonial não descartamos a possibilidade da formação de um comportamento de negociação entre o sujeito negro que criava estratégias de manutenção de seus valores em contato com a imposição civilizatória europeia. Assim podemos vislumbrar a possível conciliação entre os valores cristãos evangélicos e a identidade negra, deixando claro tal comportamento pode ser observado num contexto estritamente subjetivo.

Como descrevemos anteriormente, o interesse em discutir essa questão partiu da constatação do crescimento do quantitativo dos fiéis afro-brasileiros nas religiões pentecostais e neopentecostais e da realidade de reivindicações da valorização da história de protagonismo negro, da valorização da cultura, estética e religião dos grupos afro-brasileiros. Sendo assim refletimos se é cabível aos negros evangélicos estarem também vinculados às demandas de valorização da negritude que têm se feito presente na atualidade.

Nosso ponto de partida é refletir sobre a presença do ser negro no meio evangélico, realidade que a princípio pode parecer incompatível pelo fato de não haver nenhum interesse em se fortalecer a identidade negra através do discurso pentecostal e neopentecostal, pelo contrário, principalmente os neopentecostais demonizam os elementos da cultura africana e afro-brasileira; justamente esta questão provaria a incompatibilidade entre ser um fiel negro neopentecostal e afirmar a negritude. Visto que o que constatamos é o aumento do número de negras e negros contabilizados nas estatísticas do IBGE como seguidores do proselitismo pentecostal e neopentecostal. O resultado desse aumento do número de seguidores negros e o proselitismo proferido no meio neopentecostal poderia causar aversão do negro a sua cultura ancestral, que negro evangélico quer ser percebido como herdeiro da "raça amaldiçoada"? Que negro evangélico quer valorizar a mitologia dos orixás como forma de conhecimento cultural se o panteão afro-brasileiro é depreciado e caracterizado como algo demoníaco?

Nesse sentido é possível pensar numa identidade negra e evangélica sem contradições, ou num assimilacionismo do negro?

Apesar da realidade de intolerância religiosa, de cunho fundamentalista, praticada contra os aspectos da cultura afro-brasileira, pelo contrário, é possível percebermos atitudes de reivindicação de grupos negros evangélicos começando a fazer soar suas demandas culturais, estéticas e históricas no meio social, cultural e no espaço religioso também.

Morgane Laure Reina (2017) em seu artigo Pentecostalismo e questão racial no Brasil: desafios e possibilidades do ser negro na igreja evangélica se baseia nas afirmações de Roger Bastide (1960) a respeito da unidade de divulgação do protestantismo no Brasil que em nada diferencia seu discurso para o branco ou para o negro. Não havendo diferença no 
discurso mantém-se uma narrativa de universalização da igualdade, em que todo fiel é aceito na comunidade evangélica sem preconceito. Na verdade, a noção de irmandade criada impede que se veja a realidade de discriminação da pessoa negra. A autora concorda com Bastide (1960) que o ensinamento projetado de maneira universal resultaria na possibilidade de assimilação cultural do negro evangélico, pois este foi impedido de enxergar valor na cultura afro-brasileira.

Para entendermos a aproximação dos negros ao meio evangélico precisamos avaliar o processo histórico brasileiro, pois apenas as particularidades e subjetividades do ser humano ao preferir essa ou aquela filosofia religiosa em sua vida, não são suficientes para explicar tais escolhas. Há necessidade de pensar condições mais estruturais que promovem pensamentos hegemônicos, como foi o caso da ideologia cristã que se estruturou através de estratégias de imposição cultural, como a catequização, a obrigatoriedade do batismo, a rotina de assistir as missas, a desqualificação dos costumes e tradições indígenas e africanos e a proibição de se cultuar seus próprios deuses num processo que transcorreu todo o período colonial e imperial brasileiro; mas que ainda se faz presente, num sentido de conversão por convencimento nos projetos missionários cristãos atuais.

Ao longo do processo de diáspora negra e das estratégias de dominação colonial o sujeito negro vai perdendo referenciais marcantes de sua cultura e história, tornando-se presa fácil do contexto assimilacionista colonial. Kabengele Munanga observa que a falta de vínculo identitário na comunidade negra brasileira, principalmente no que diz respeito às diferenças religiosas foi resultado de longo processo das estratégias de imposição e desqualificação cultural que os costumes e tradições negras sofreram. Nesse sentido, o fato de ser afro-brasileiro não representa quesito para ser praticante da umbanda e candomblé, por exemplo.

O sujeito negro perdeu o contato com sua cultura e a falta de interação entre elementos históricos e linguísticos impediram a criação de conscientização a respeito da ancestralidade do povo negro. Disso resultou a assimilação dos negros da diáspora às culturas europeias. Muito embora elementos especificamente característicos da cultura afro-brasileira tenham sidos associados à cultura nacional, não causaram impacto de valorização da história e cultura negra impedindo a formação de uma identidade cultural comunitária.

A noção de uma identidade cultural comunitária é complicada, visto que é ainda uma tendência o negro cristão rejeitar não só as religiões de matrizes africanas, como outros elementos do universo afro-brasileiro. Contudo da mesma forma que a categoria identidade foi usada para realçar o problema em se construir uma comunidade negra, pois os negros em 
diáspora não conseguiram formaram uma identidade coletiva, poderíamos pensar a mesma categoria como impeditivo para formar um coletivo evangélico negro genérico que ignora ou despreza a cultura africana e afro-brasileira?

A resposta é dada por Morgane Laure Reina, em que a autora apresenta a pesquisa de Márcia Leitão Pinheiro sobre religião, raça e música na qual se retrata o espaço musical gospel como uma forma de se expandir noções sobre negritude. Ainda assim, penso ser necessária a ampliação dos estudos e entendimentos sobre a cultura africana e afro-brasileira para evitar interpretações raciais que operam em demarcar a cultura afro-brasileira como inferior. Mas identificar novos olhares sobre como o negro vem projetando sua negritude através da música, por exemplo, é um bom passo para constatarmos que não há inteiramente uma assimilação, mas uma fusão cultural tendo o negro como articulador também do que se resulta de tais aproximações culturais.

Opinião semelhante é apresentada por Petrônio Domingues (2011) quando o autor denomina a característica afro-diaspórica como sendo o comportamento do negro em entender este enquanto o sujeito que aprender a viver em renovação. A história do ser negro é marcada por inúmeras experiências que lhe permitiram adquirir comportamento perspicaz pronto a enxergar ou a experimentar novas possibilidades.

A respeito de pensar o afro-brasileiro como um ser múltiplo em decorrência do que experimentou e continua experimentando do processo diaspórico, Petrônio Domingues nos diz o seguinte:

\footnotetext{
Para estudar o negro no pós-abolição, recomenda-se, igualmente, desconsiderar as abordagens essencialistas das identidades e culturas negras. Em vez de fixas, naturalizadas e congeladas, as identidades e culturas dos indivíduos são construções dinâmicas, relacionais, fluidas e concatenadas em cada situação específica. Os negros articularam identidades plurais, estabeleceram fronteiras étnicas móveis e transigiram formas culturais híbridas. Não param aqui os desafios dessa nova área de estudos e pesquisas, de modo que se deve surpreender os afro-catarinenses pelo prisma de suas tradições, acomodações e ambivalências, atentando para os diferentes sentidos e significados que eles conferiram à sua maneira de ser, pensar e agir. (DOMINGUES, 2011, pag. 132)
}

Portanto no que diz respeito à relação entre identidade afro-brasileira e identidade religiosa neopentecostal identificamos o protagonismo do negro quando este elemento afirma sua negritude ao trançar o cabelo, ou na escolha de estilos de roupas que evoquem a cultura afro e ao participar de atos em defesa da cultura e religiosidade afro-brasileira como, por exemplo, os casos de intolerância religiosa que afetam em maior volume os terreiros de umbanda e candomblé. É verdade que muito precisa ser pensado a respeito da identidade negra evangélica em como pertencer a dois universos tão díspares, mas o fato é que existem grupos evangélicos em defesa da cultura e ancestralidade afro-brasileira como a associação tal fala como é. E como bem nos alertou E. P. Tompson ao pensar a história "vista de baixo", os grupos das classes "inferiores" são tão 
agentes quanto os grupos das classes "superiores", devem ser analisados como aquele elemento que afeta em maior ou menor grau o ambiente compartilhado coletivamente. Podem não ser todos, mas os negros evangélicos de cunho neopentecostal estão atentos ao racismo criando estratégias para sobressair sua cultura seu legado.

Portanto o que pode parecer apenas um comportamento de assimilação do negro, na verdade está permeado de prováveis estratégias de possibilidade e negociações, mesmo que não haja ímpeto de consciência, há formulações de estratégias de vida pautadas na cultura afro-brasileira.

Neste ponto nosso dilema é entender as estratégias para referendar a negritude no seio cristão evangélico, principalmente neopentecostal, se este produz um discurso de aversão aos elementos da cultura afro-brasileira.

Morgane Laure Reina (2017), afinada ao pensamento de Guimarães (2003), afirma não haver consenso na categoria identidade negra. Não havendo consenso identitário será na subjetividade que encontraremos a resposta para entender como os negros evangélicos que defendem ou se articulam em defesa da cultura afro-brasileira agem. Seria consciência política de reconhecimento da cultura negra como pertencente a história brasileira, seria afeto por já ter feito parte do meio religioso de matriz afro-brasileira, seria noção de igualdade de direitos, podemos encontrar inúmeras identificações dos negros evangélicos. O interessante não é apenas descrever tais identificações, mas entende a identidade como um resultado de processos sócio-históricos em que o indivíduo negocia sua sobrevivência de forma subjetiva.

Reina (2017) nos apresenta um depoimento da diretora da Aliança de Negras e Negros Evangélicos do Brasil (ANNEB) de como uma parcela dos negros evangélicos tem atuado a respeito da defesa da cultura afro-brasileira. Vejamos o relato da pastora Waldicéia apresentado por Morgane Laure Reina:

\footnotetext{
Fui para São Paulo fazer uma palestra num fórum, que a gente da ANNEB sempre faz quando alguém é vítima de discriminação, preconceito e racismo na igreja... A gente aparece lá, primeiro para conversar com a vítima e dar a opção de irmos no próximo culto em que aconteceu: um monte de preto, tudo caracterizado, turbante, mante de preto, etc. se sentar nos primeiros bancos da igreja de frente para o pastor e colocar no meio da gente a vítima. Sem falar nada, assiste o culto normalmente. Aí quando o culto termina, eu como presidenta da ANNEB procuro o pastor (...): "Pastor, chegou até nós a denúncia tal da nossa irmã fulana de tal, nós já ouvimos ela, queremos ouvir o senhor”. Quando ele termina, falamos: “(...) Nós somos do movimento social negro, e segundo a lei tal tal tal, o que o senhor fez é crime. Nós já colocamos ela [a vítima] para escolher: ou juntamos todos nós e vamos com ela e um advogado em uma delegacia denunciar o senhor pela prática de discriminação, preconceito e racismo, ou o senhor abre a igreja a semana que vem para que nós façamos um fórum temático sobre discriminação, preconceito e racismo na igreja protestante, onde nós vamos chamar representante do movimento social negro na primeira mesa. Na segunda mesa, eu como presidenta da ANNEB, vou falar sobre a
} 
legislação que existe hoje sobre discriminação, preconceito e racismo. O presidente da ANNEB nessa unidade da federação vai falar sobre discriminação, preconceito e racismo na Bíblia. E depois a gente abre para o debate. E no final, o senhor se retrata na frente de todas e todos que estão ali. O senhor escolhe, são duas alternativas que o senhor tem". Não precisa nem dizer que todos eles escolhem o fórum, né... (REINA, 2017, págs. 271 e 272).

A ANNEB demonstra claramente o reconhecimento da estrutura racista de nossa sociedade. Não só por denunciar atitudes racistas dentro da Igreja, mas ao se apropriarem da indumentária africana num culto evangélico demarcam o reconhecimento cultural autorizando coletivamente o uso de tais trajes encorajando negras e negros a assumirem se quiserem sua negritude sem cair no aspecto conotativo, mesmo que ainda haja a crítica ao uso. Porém ficará registrada na memória dos fiéis um processo jurídico ou o reconhecimento da atitude racista vinda do pastor ou outro intergrante. Em vista disso, não podemos pensar numa identidade sociocultural fixa, pois por meio das relações raciais, adaptações, valores e atitudes os negros da diáspora protagonizaram as melhores escolhas para garantir uma vida digna.

A autora se baseia na histórica resistência negra evangélica inspirada no modelo norte-americano de ação política em que se constituiu o Movimento Negro Evangélico na década de 1980. Este movimento possibilitou a criação da noção de comunidade negra apoiada em lutar por melhorias socioeconômicas. Nesse sentido negros evangélicos congregariam noção de pertencimento a respeito de uma raça que tinha seus direitos vilipendiados. Diferente da cultura estadunidense o racismo brasileiro não era tão direto, mas mascarado em forma de democracia racial, mesmo assim o MNE atuava em prol de melhorias socioeconômicas para o grupo negro evangélico.

Portanto os negros evangélicos possuem a experiência de discutir política, um dos importantes repertórios de aplicação da luta negra no Brasil, a luta por melhorias dos direitos socioeconômicos.

Outro indício se desenvolveu dentro do próprio protestantismo de caráter neopentecostal. Não são poucas as igrejas evangélicas propensas a trabalhar a hermenêutica religiosa de matriz afro-brasileira numa liturgia que mais se assemelha aos cultos afrobrasileiros. Basta lembrar das práticas de incorporação do que os evangélicos chamam de espírito santo, mas que toda performance do incorporado nos lembram as entidades dos cultos afro-brasileiros, o transe, o falar em línguas, a apropriação do uso do sal grosso, do galho de arruda, a distribuição da bala ungida para crianças no dia de Cosme e Damião, são exemplos de apropriação dos elementos das religiões de matrizes afro-brasileiras pela instituição religiosa neopentecostal. 
Entendemos a ocorrência da apropriação cultural, identificamos a ressignificação que o discurso neopentecostal dá aos elementos culturais afro-brasileiros e percebemos a demonização dos elementos religiosos por parte do discurso fundamentalista religioso partido dos grupos neopentecostais, como parte de uma disputa religiosa.

O neopentecostalismo ao manter os elementos dos cultos afro-brasileiros permitem a aproximação de novos fieis acostumados com a incorporação, ou atraem outros ávidos pela experiência de religiões com forte apelo a magia (Gonçalves, 2011), com o diferencial de que sendo a magia administrada por uma ramificação do cristianismo demonstra-se legitimidade social por conta da questão hegemônica.

Outra importante questão avaliada por Ricardo Mariano (2011) que explicaria a concorrência religiosa, refere-se ao fato de que os cultos afro-brasileiros serem reconhecidos por solucionar os problemas através da "prestação de serviço" das entidades para os problemas materiais e espirituais dos seguidores, portanto ao tomar para si a organização da incorporação ressigificando-a como algo negativo o pentecostalismo demonstra mais poder sobre as práticas e entidades religiosas afro-brasileiras demarcando discurso como verdade.

A principio a peculiaridade dos cultos neopentecostais pode indicar assimilação por meio das estratégias de negação, ressiginificação da cultura afro-brasileira. Contudo o que caracteriza os cultos afro-brasileiros é a experiência do avivamento, portanto ainda que de forma desvalorizada e por interesse mercadológico, os elementos culturais afro-brasileiros permanecem presentes no espaço cristão. Dessa forma ao invés de uma cultura assimilada, podemos pensar uma nova forma de pensar o ser negro que impõe sua marca filosófica.

Adentrando ainda mais nessa questão da possível identidade negra evangélica tomamos como referência o artigo de Marcio Goldman (2017) Contradiscursos afroindígenas sobre mistura, sincretismo e mestiçagem estudos etnográficos com intuito de demarcar novas maneiras de enxergar os estudos que dizem respeito a categoria identidade. Goldman reflete sobre a dissertação de mestrado de Cecília Campello do Amaral Mello de 2003 a respeito de um grupo sociocultural autointitulado afroindígena. O interesse de Mello (2003) era entender o que o grupo efetivamente queria dizer sobre si mesmo para evitar as determinações que já eram clássicas pelos estudos etnográficos. Segundo Goldman, a autora:

Pôde aprender com eles, assim, que afroindígena não precisa necessariamente ser entendido como algo da ordem da identidade, nem do pertencimento, mas do devir do que se torna, do que se transforma em outra coisa diferente do que se era e que, de algum modo, conserva uma memória do que se foi” (GOLDMAN, 2017, pág 12) 
Ponderando nossa análise sobre a construção de uma possível identidade negra evangélica, tomamos como base os estudos de Cecília Campello do Amaral Mello, para pensar numa transformação subjetiva de alguns negros neopentecostais que se tornam diferentes daquilo que o discurso do púlpito demarca como condição para ser um bom fiel. Cabe ressaltar então que o discurso institucional de demonização de imagens de elementos das culturas africanas e afro-brasileiras, especialmente aquelas ligadas aos aspectos religiosos, pode ser passível crítica, em certa medida, por novos discursos de negros neopentecostais que rejeitam atitudes de intolerância e têm apreço ao respeito pela diversidade.

Como bem aplicou Mello a sua pesquisa o princípio de irredução também, podemos pensar a respeito desse conceito denominado por Bruno Latour para nosso perfil analisado, o sujeito negro evangélico. O que Latour nos apresenta é a possibilidade de pensar nosso sujeito não apenas como uma oposição entre duas identidades, mas uma nova formação identitária construída na base da relação que resulta num "modo particular de articular diferenças" (GOLDMAN, 2017, pág. 12)

O contexto em que essas identidades se apresentam é relacional, ora se abstrai um conteúdo para fazer valer o outro ora ambos se conectam sem que haja constrangimento algum como é o caso da afirmação do cabelo afro trançado ou o uso de turbantes no ambiente neopentecostal. O desencontro afro-ibérico resultou num maior processo de desterritorializaçao, mas reterritorialização da história da diaspora provocando mais no elemento negro do que no branco ajustes culturais.

Fica claro observando hoje o comportamento de negros neopentecostais que estão afinados com o respeito à diversidade que, mais do que uma condição de adaptação da cultura afro-brasileria aos ditames civilizatórios europeus, o que percebemos foi a ocorrência de novas formulações socioculturais.

Goldman (2017) recorre a Roger Bastide (1973) para criticar a tendência antropológica que afirma haver nas relações culturais processos adaptativos, no caso das religiões de matrizes africanas que seriam compreendidas numa relação subordinada à cultura cristã. Esse tipo de compreensão nos causou ver o mundo de forma uniformizada, evolutiva e sectária, porque se o aspecto estudado não fosse da ordem do universal ou nacional era descartado. Por isso a necessidade de afirmar a fusão cultural, como foram entendidas até então as formas de sincretismo (no caso da umbanda como forma do praticante promover a justaposição do sagrado) ou o segregacionismo religioso quando não havia possibilidade de perceber a subordinação (no caso o candomblé que cultua orixás que em nada se assemelham 
ao proselitismo cristão). Até porque como bem salienta Goldman a respeito do texto de Clara Flaksman o que foi interpretado como sincretismo religioso:

“... não é simplesmente um modo de incorporar a religião e os valores brancos, mas bem ao contrário, um modo de, ao fazê-lo, ser capaz de mantê-los a uma certa distância e submetidos a uma lógica que não é a deles. (...). O que significa que as próprias diferenças são diferentes e que não há regra geral sobre como estabelecer relações entre diferentes tradições ou forças religiosas..." (GOLDMAN, 2017, pág 18)

Substituindo o discurso institucional neopentecostal por novas narrativas subjetivas de aceitação da diversidade podemos estar diante de processo de modulação da diversidade, como afirma Goldman ao se referir aos constradiscursos que rejeitam homogeneização cultural. A modulação é um processo de variação contínua em que diferentes culturas podem coexistir se combinando ou se distinguindo. Além do mais o negro neopentecostal ao ser simpatizante da diversidade cultural e ao respeitar as religiões de matrizes africanas demonstra ser capaz de manter uma certa distância do discurso institucional propagado em sua igreja e na mídia em geral em que ressoa em alto e belo tom a liturgia da demonização cultural afro-brasileira, nesse sentido cria uma nova lógica que não é divulgada no meio institucional. Por conseguinte, o sujeito negro neopentecostal pode ser compreendido como um elemento social em experiência de modulação, pois nele coexistem duas formas culturais a princípio conflitantes a de ser negro e valorizar sua ancestralidade e a de ser neopentecostal e ter que carregar em seu imaginário a religiosidade africana como algo demoníaco. Segundo Goldman:

\footnotetext{
"O acoplamento desses saberes, bem como seu confronto, ainda que implícito, com os saberes eruditos abre caminho para o mapeamento, a aliança e a ativação dos contradiscursos sobre o sincretismo e a mestiçagem, de modo a contribuir para que apareçam com uma força ainda maior do que a que já possem". (GOLDMAN, 2017, pág. 16)
}

Podemos encarar a identidade negra evangélica como um resultado do confronto cultural entre a ideia de tornar-se negro, e valorizar elementos da cultura negra, mas não ter que abandonar a fé já instituída como questão de foro íntimo, mesmo sabendo que o "foro intimo", hoje algo internalizado, foi construído historicamente por imposição cultural religiosa através das estratégias de catequização europeia.

Talvez esteja cede demais para afirmar que ser um negro neopentecostal é demonstrar consciência da hegemonia cristã sobre as demais formas de se referir ao sagrado, portanto não podemos restringir a discussão, mas apresentá-la para que surjam futuros debates e novos víeis interpretativos. Por enquanto ficaremos com a possibilidade de atribuir ao negro 
neopentecostal a coragem em resistir aos modelos ideológicos que inserem o elemento afrobrasileiro ao descaso, a invisibilidade e incompreensão cultural, sabendo que em seu meio cultural religioso será classificado como aquele que sede às tentações demoníacas. Como foi o caso apresentado por Reina (2017, pag. 261) em que uma menina negra resolveu parar de alisar o cabelo e passou a fazer tranças. Concordamos com a autora que identificou na jovem uma decisão estética, e reivindicação de sua identidade negra. Mas num culto de sua igreja, na frente do público, o pastor a expôs constrangendo-a na frente da comunidade inteira por ter trançado o cabelo e assim ter cedido as tentações do demônio. Dessa experiência podemos pensar o meio estético como canal para iniciar a transformação hibrida entre ser negro e manter sua fé neopentecostal. Mas quem sabe pode ser o caminho para se refletir sobre o discurso neopentecostal que insiste em demonizar a cultura negra e enxergar nessa prática uma das modalidades do racismo estrutural, pois independente de estar ou não na igreja o negro sofrerá igualmente o racismo, com certos atenuantes devido a construção estereotipada que negros macumbeiros carregam, mas o fato de ambos serem negros o racismo os atravessa.

A identidade negra neopentecostal é algo diferente do que se espera que um negro seja dentro do neopentecostalismo, pois o negro neopentecostal que participa de uma caminhada contra a intolerância religiosa, vai a grupos de estudos sobre intolerância religiosa, ou aplica de fato a Lei 10.639/03 apresentando a diversidade cultural de nosso país como potencialidade criadora, rejeita a construção ideológica mantida pelo mito da democracia racial, seu pensamento opera analisando as perdas históricas da cultura negra por isso a necessidade do resgate histórico cultural. O negro neopentecostal que assume uma postura política em relação ao sua negritude é um diferencial. Na análise de Goldman (2017, pág.25) “... o diferencial não pode ser encarado como mera negação e/ou oposição uma vez que ele é sobretudo da ordem da criação ou da criatividade". Nesse sentido devemos pensar que se ao negro da diáspora foi imposta nova condição cultural dela não ocorreu submissão total, mas comportamentos negociadores que perpassavam por estratégias criativas para garantir a sobrevivência não só do elemento negro como sua própria cultura.

\section{Bibliografia}

ANJOS, JOSÉ CARLOS GOMES DOS e ORO, ARI PEDRO. Festa de Nossa Senhora dos Navegantes em Porto Alegre: sincretismo entre Maria e Iemanjá. Porto Alegre: SMC, 2009 [Capítulo 5, parte I] e [Capítulos 1 a 6, Parte II].

GOLDMAN, MARCIO. Contra discursos afroindígenas sobre mistura, sincretismo e mestiçagem estudos etnográficos. Revista de Antropologia da FUSCar, São Paulo, vol 9, n.2, p 11-28, jul./dez. 2017. 
MUNANGA, Kabengele. Negritude. Usos e sentidos. Belo Horizonte: Autêntica Editora, 2012

ORTIZ, FERNANDO. Los negros brujos. Miami: Ediciones Universal, Colección Ebano y Canela 2, 1973.

REINA, Morgane Laure. Pentecostalismo e a questão racial no Brasil: desafios e possibilidades do ser negro na Igreja evangélica. Plural, Revista do Programa de Pósgraduação em Sociologia da USP, São Paulo, v 24.2, 2017, p. 253-275.

RODRIGUES, RAIMUNDO NINA. O animismo fetichista dos negros bahianos. Rio de Janeiro: Civilização Brasileira, 1935.

SERRA, ORDEP. "Sincretismo e Separação" [Capítulo 2]. In: SERRA, ORDEP. Águas do rei. Petrópolis/Rio de Janeiro: Vozes e Koinonia, 1997, p. 191-287.

Sites:

www.cartacapital.com.br/blogs/dialogos-da-fe/a-identidade-negra-e-os-neopentecostais-saoincompativeis publicado 04/05/2018 18h10, última modificação 04/05/2018 11h33. Acesso: 06/08/2018.

https://institutoparacleto.org/2012/12/01/a-religiao-mais-negra-do-brasil-opentecostalismo/Acesso: 07/08/2018. 


\title{
O problema insider-outsider nas religiões afro-brasileiras
}

\author{
The insider-outsider problem in afro-brazilian religions
}

Amurí Amaral Ribeiro ${ }^{19}$ amuriar@gmail.com

\begin{abstract}
Resumo: O trabalho tem como objetivo debater a problemática do pesquisador insideroutsider no cenário das religiões afro-brasileiras. Inicialmente apresento essa problemática tal como foi abordada pelos autores Engler e Gardiner (2010). Num segundo momento, apresento os conceitos de estabelecidos e outsiders, tal como foi trabalhado por Norbert Elias (2000). Por fim, utilizo os conceitos trabalhados pelos autores anteriores para analisar o trabalho de Vagner Silva (2015), no qual ele estuda as pesquisas etnográficas das religiões afrobrasileiras. Ao confrontar as teorias de Engler \& Gardiner e Elias com as narrativas apresentadas por Vagner Silva e seus entrevistados, percebe-se que, no caso específico das religiões afro-brasileiras, há sim uma diferença no acesso ao conhecimento entre pesquisadores adeptos e céticos.
\end{abstract}

Palavras-chave: Insider-outsider. Religiões Afro-brasileiras. Estabelecidos. Outsiders

Abstract: The objective of this work is to discuss the insider-outsider researcher's problem in the Afro-Brazilian religions scenario. I first present this problem as it was approached by the authors Engler and Gardiner (2010). In a second moment, I present the concepts of established and outsiders, as worked by Norbert Elias (2000). Finally, I use the concepts developed by the previous authors to analyze the work of Vagner Silva (2015), in which he studies the ethnographic researches of the Afro-Brazilian religions. Confronting the theories of Engler \& Gardiner and Elias with the narratives presented by Vagner Silva and his interviewees, we can see that, in the specific case of Afro-Brazilian religions, there is a difference in access to knowledge between adept and non adept researchers.

Keywords: Insider-outsider. Afro-Brazilian religions. Outsiders

\section{Introdução}

Um debate importante que se deve ter em mente todo pesquisador que estuda alguma religião é a questão da capacidade que o pesquisador possui de acessar o universo do grupo que ele pesquisa, e a partir desse acesso produzir um conhecimento científico disso. Essa relação entre pesquisador e objeto é questionada por diversos autores dentro das várias áreas das ciências humanas. Na Ciência da Religião esse debate costuma aparecer como o dilema do pesquisador insider-outsider. Essa visão aponta para o fato de que observadores adeptos (insiders) e observadores céticos (outsiders) teriam pontos de vistas divergentes. Para alguns, a pesquisa científica exige uma postura racional e crítica que não possibilita uma referência

\footnotetext{
${ }^{19}$ Mestrando no Programa de Pós-graduação em Ciência da Religião - UFJF. Graduado em Ciências Sociais pela Universidade Federal de Viçosa.
} 
pautada na fé. Para outros, o saber religioso possui uma singularidade que só é acessível aqueles que compartilham de tal sentimento.

O presente artigo tem como objetivo debater a questão do pesquisador insider-outsider na prática da pesquisa e do trabalho de campo com grupos religiosos. Devido a amplidão desse debate, irei focar o cenário das religiões afro-brasileiras. Para isso, irei analisar o livro "O antropólogo e sua magia" de Vagner Gonçalves da Silva (2015), no qual o autor apresenta seu trabalho de doutorado em que ele analisa as etnografias das religiões afrobrasileiras. O livro de Vagner é recheado de exemplos que demonstram as dificuldades e relações de poder na pesquisa etnográfica com comunidades religiosas. As religiões afrobrasileiras possuem especificidades que demonstram desafios específicos, como o fato de ser uma religião iniciática e estigmatizada.

Como metodologia, irei inicialmente apresentar o debate insider-outsider através do artigo "A filosofia semântica e o problema insider-outsider" dos autores Steven Engler e Mark Q. Gardiner (2010). Nesse artigo, os autores defendem que não há diferença no acesso ao conhecimento entre pesquisadores adeptos e céticos. Em seguida, irei apresentar a perspectiva teórica de Norbert Elias (2000) sobre a questão estabelecidos-outsiders devido suas importantes contribuições para entender as relações de poder. Por fim, irei utilizar a perspectiva teórica desses autores para analisar a narrativa apresentada por Vagner Gonçalves da Silva em seu livro "O antropólogo e sua magia” (2015). Com os exemplos encontrados no livro de Vagner, ficará claro que conclusões filosóficas, tais como a apontada por Engler e Gardiner, não são suficientes para responder o problema de forma prática.

\section{O problema}

Um dos debates presentes no que tange a pesquisa do universo religioso é a relação do pesquisador com a religião que ele pesquisa. Para alguns, seria exigência uma mínima relação íntima com a religião, sendo que adeptos teriam um privilégio na compreensão, por terem acesso a informações e sentimentos que as pessoas de fora não possuem. Já para outras pessoas, o pesquisador outsider teria um privilégio ao conseguir ver com clareza aspectos que os adeptos tomam com naturalidade. Há diversos textos e autores que abordam esse tema. Não irei aqui buscar uma síntese do debate, mas sim apresentá-lo de uma forma geral e confrontá-lo com os discursos da prática de pesquisa apresentados pelos antropólogos entrevistados no livro de Vagner G. da Silva (2015). 
Engler e Gardiner (2010), buscando debater sobre o "problema" insider-outsider, chegam à conclusão que "do ponto de vista teórico do holismo semântico, não existe uma diferença fundamental entre insider e outsider" (p. 90). Os autores não negam que exista uma diferença relativa. Segundo eles, é importante diferenciar a visão sociológica da existência da relação insider-outsider, das perguntas levantadas por essa separação.

Segundo os autores:

“A pergunta-chave do suposto problema insider-outsider é a seguinte: até que ponto
o pesquisador acadêmico não-religioso pode entender - no sentido de interpretar
corretamente - os comportamentos, crenças, ou experiências das pessoas religiosas;
isto é, até que ponto o cientista da religião 'outsider' pode entender ou interpretar os
estados mentais religiosos dos adeptos 'insiders'?" (Engler \& Gardiner, 2010, p. 99)

Segundo os autores, haveria duas versões desse problema, uma sociológica e outra religiosa, assim como duas formas de "insiderismo": o insiderismo relativo e o insiderismo absoluto. O insiderismo relativo tem como função apontar um fato sociológico básico, de que diferentes indivíduos possuem diferentes níveis de conhecimento sobre determinado objeto, dessa forma, aponta pro desafio metodológico da pesquisa científica. "De certa maneira, se não fosse o insiderismo relativo, não existiria motivo para o estudo da religião" (Engler \& Gardiner, 2010, p. 93). Já o insiderismo absoluto, "levanta um problema sério para o estudo da religião, insistindo, por exemplo, que só os xamãs podem estudar o xamanismo" (Engler \& Gardiner, 2010, p. 93). Segunda essa perspectiva, só os iniciados teriam condição de falar e compreender sobre o universo religioso. Os insiders são os que sabem, e os outsiders nunca poderão saber. Dessa forma, há uma relação inversa entre os dois tipos de insiderismo, um servindo de condição prévia para a realização de qualquer pesquisa e o outro, justamente, negando tal possibilidade.

O insiderismo absoluto limita não só a capacidade da realização de pesquisas como apresenta uma visão contrastante e simplista da realidade, separada entre iniciados e não iniciados, sem considerar os graus de pertinência existentes nos grupos sociais e religiosos. Assim como também ignora a multiplicidade de identidades que os indivíduos vivenciam, como classe, gênero, raça e idade. Segundo os autores, o insiderismo absoluto pode se apresentar em duas versões, uma sociológica e outra religiosa. $\mathrm{Na}$ versão sociológica se considera que os insiders possuem uma posição social privilegiada que os possibilita o acesso a determinadas formas de conhecimento. Já na versão religiosa, acredita-se que a distinção seja devido a forma diferenciada de relação que o adepto estabelece com o universo religioso. Essa visão aponta para existência de um modo distinto de percepção religiosa de um tipo sui 
generis, restrita a quem compartilha daquela fé, daquele universo. Dessa forma, "é a própria natureza excepcional do conhecimento religioso que concede aos insiders um monopólio do conhecimento (Enlger \& Gardiner, 2010, p. 94). O insiderismo absoluto religioso pode se apresentar de duas formas: uma universal, que considera que só as pessoas religiosas compreendem o sagrado, mas que, uma pessoa religiosa poderia compreender o sagrado de outra pessoa; e a forma relativa, que considera que somente pessoas de determinado seguimento religioso podem compreendê-lo.

Após essa apresentação do problema insider-outsider, Engler e Gardiner chegam a conclusão de que o problema se encontra em torno do "insiderismo absoluto religioso", sendo esse um problema de ordem filosófica e semântica.

\begin{abstract}
“A versão relativa de insiderismo não gera nenhum problema'; levanta uma série bem conhecida de desafios metodológicos. O 'problema' surge com o insiderismo absoluto. Sua versão sociológica parece falhar por vários motivos, deixando apenas a versão religiosa. Contudo, desde que a mesma é explicitamente baseada em afirmações quanto à natureza do conhecimento e da significação religiosa, só pode ser defendida ou criticada com base na teoria epistemológica e semântica. Isto é, o problema insider-outsider no estudo da religião é, no fundo, um assunto filosófico. Portanto, qualquer discussão da sua natureza, ou até da sua existência, necessita que nós usemos os instrumentos da filosofia." (Engler \& Gardiner, 2010, p. 95)
\end{abstract}

\title{
O holismo semântico
}

Engler e Gardiner optam pela teoria do holismo semântico para a solução desse problema. Como motivo da escolha, eles irão apontar a importante relevância e influência dessa perspectiva nos estudos da ciência da religião. Como referência, eles utilizam a formulação teórica de Donald Davidson sobre o holismo semântico.

Segundo os autores, o holismo semântico se contrapõe as teorias "atomísticas". Os atomistas acreditam que os elementos semânticos básicos (palavras, frases) possuem significado independente das relações estabelecidas com outras unidades semânticas. Já as teorias holísticas, acreditam que o significado de qualquer elemento semântico é essencialmente conectado a outros elementos semânticos, podendo-se considerar a língua inteira como uma unidade semântica.

"Para resumir, de forma bem pouco rigorosa: se você afirmar que o significado se acha nas palavras, você é atomista; se você afirmar que ele é uma função de uma rede de relações contextualizada e muito mais ampla, você é holista." (Engler \& Gardiner, 2010, p.96) 
A visão do holismo semântico considera que não há nada que possa ser identificado como o significado absoluto de determinado elemento da linguagem. O significado é compreendido de uma forma dinâmica. Ele se define através de uma complexa rede de relações com palavras, crenças e frases. Há, portanto, um elemento de mutabilidade, que faz com que o significado não possa ser considerado algo único, estável e estático. O significado deve ser compreendido em termos de interpretação. Essa visão critica a possibilidade de alguma forma de significado religioso absoluto e transcendente.

O holismo semântico também nega a divisão absoluta da linguagem em áreas de conhecimento. Dessa forma, nega a autonomia da linguagem religiosa.

\begin{abstract}
"Qualquer compreensão da afirmação 'Yahweh chamou Moisés na forma de uma sarça ardente' mistura itens de assuntos e de áreas tradicionalmente diferentes, p. ex., a tradição bíblica judaica, a botânica e a combustão. O significado de cada vértice dessa rede é dado por suas relações a outras, e assim por diante. Afirmar que o assunto da proposição é especificamente religioso indicaria um enfoque básico interesse em algum subconjunto da rede semântica - , mas tal afirmação não identificaria nenhuma categoria semântica (ou ontológica) fundamental. Se entendermos o significado em termos holísticos, a religião não poderá ser um material sui generis de estudo. (Engler e Gardiner 2010:281)" (apud Engler \& Gardiner, 2010, p. 98)
\end{abstract}

Essa perspectiva filosófica, tal como é trabalhada por Davidson, tem como premissa que o pensamento é fundamentalmente uma atividade lingüística, logo, entender a linguagem auxilia na compreensão dos estados mentais dos sujeitos. A distinção insider-outsider tem como premissa básica a dificuldade que o pesquisador teria para acessar os estados mentais dos pesquisados. Há a idéia implícita de "que existem impedimentos fundamentais ao acesso genuíno aos estados mentais das outras pessoas" (Engler \& Gardiner, 2010, P. 100). Essa premissa tem como base a tese da incomunicabilidade da linguagem do insider, de que essa seria privada de sentido pro outsider. É como se não fosse possível interpretar o que é dito pelo adepto por alguém "de fora". Segundo os autores, essa visão nega a racionalidade do adepto e da própria experiência religiosa.

\footnotetext{
“Se não pudéssemos interpretar a 'linguagem' do outro em nosso próprio idioma, não teríamos absolutamente nenhuma razão para supor que este 'outro' falasse uma língua, ou mesmo que fosse 'racional'." (Engler \& Gardiner, 2010, p. 100)
}

Para o holismo semântico, o significado se constrói através da interpretação, a partir das relações que se estabelece. Nega-se, portanto, qualquer autoridade e prioridade semântica com base no acesso ao fenômeno. Dessa forma, o pesquisador adepto não possuiria uma visão 
semântica privilegiada. Pelo contrário. O holismo semântico nega a dicotomia insideroutsider. Segundo essa visão, essa dicotomia só seria possível levando-se em conta a incomunicabilidade e irracionalidade do fenômeno religioso.

\footnotetext{
"Quando entendemos a significação em termos de uma larga rede da interpretação e não como algo ligado a elementos individuais de linguagem -, simplesmente não há nenhum problema de insider-outsider. O holismo semântico nega esse problema, sendo que insiders e outsiders significam o que significam pelo mesmo modo público em linguagens que podem ser interpretadas exatamente da mesma maneira. O único motivo para tratar os insiders como se fossem imunes à interpretação seria se os considerássemos completamente não racionais, incapazes de ter estados mentais intencionais. Do ponto de vista de uma semântica holística, o insiderismo absoluto falha, tanto nas suas versões sociológicas quanto nas religiosas." (Engler \& Gardiner, 2010, p. 102)
}

A conclusão que chegam Engler e Gardiner em seu artigo é de ordem filosófica. Ela contribui no sentido que aponta a necessidade de se considerar a narrativa do adepto como uma narrativa racional com uma igualdade de valor com a narrativa do pesquisador outsider. É a função comunicativa presente no universo religioso que também se faz presente em todas as outras formas de discurso. Porém, criticando a conclusão dos autores, há uma especificidade de certas linguagens religiosas, como é o caso das religiões afro-brasileiras. Como será exposto mais a frente, essas religiões possuem todo um universo específico de linguagem, que exigem do pesquisador a capacidade de traduzir e interpretar esse universo para a linguagem acadêmica. E é nesse papel de "tradutor" que o pesquisador desempenha que se encontra a dificuldade e os problemas apontados pelo debate insider-outsider.

Também se pode criticar a insuficiência dessa conclusão de Engler e Gardiner, para com o que vivencia o pesquisador que estuda, através do trabalho de campo, as religiões brasileiras. Os desafios da prática do trabalho de campo apresentam tensões que expressam esse problema insider-outsider. Mais do que uma questão de semântica, o que ocorrem são tensões devido as relações de poder que se estabelece entre pesquisadores e pesquisados. Buscando complementar essa conclusão do artigo de Engler e Gardiner, irei apresentar a visão de Norbert Elias sobre a questão estabelecido-outsider.

\section{Os estabelecidos e os outsiders}

A relação insider-outsider implica uma idéia de pertencimento a um lugar social, do contraste de um nós-eles. Essa temática do pertencimento social é abordada sobre a forma de estabelecidos-outsiders, por Norbert Elias. 
Elias (2000) em seu livro "Os estabelecidos e os outsiders" apresenta um panorama geral sobre essa temática. Ao invés de utilizar o termo insider, Elias utiliza establishment (estabelecido), que é um termo de origem inglesa que faz referência a grupos e indivíduos que possuem posições de prestígio e poder, é a "boa sociedade". Dessa forma, evidencia-se a importância da dimensão do poder na forma de uma minoria dos melhores que representa o modelo ideal de moral para todos, num contraste com os outsiders, que são os excluídos e estigmatizados, que representam os desvios, o que não se deve ser socialmente.

A origem de um grupo tido como estabelecido se da a partir da produção de uma autoimagem do grupo dominante como possuidor de um carisma grupal distintivo e singular.

\footnotetext{
"[...] os grupos mais poderosos, na totalidade desses casos, vêem-se como pessoas "melhores", dotadas de uma espécie de carisma grupal, de uma virtude específica que é compartilhada por todos os seus membros e que falta aos outros. Mas ainda, em todos esses casos, os indivíduos "superiores" podem fazer com que os próprios indivíduos inferiores se sintam, eles mesmos, carentes de virtudes - julgando-se humanamente inferiores". (Elias, 2000, p. 20)
}

A relação estabelecidos-outsiders de Elias pode ser melhor compreendida ao juntá-la com a teoria de campos de Bourdieu (2011). Segundo Bourdieu, a realidade social pode ser analisada a partir da idéia de campos. Os campos seriam recortes analíticos da realidade concreta, possibilitando a análise da complexidade real de uma forma crítica. Esse paradigma dos campos é bastante utilizado na ciência da religião, por exemplo, se fala de um campo religioso brasileiro. Esse campo possui seus próprios tipos de capitais simbólicos. Dentro dele dialogam e disputam as diversas religiões do cenário brasileiro. Todo campo, segundo Bourdieu, possui certa autonomia, ao mesmo tempo em que é perpassado pelos outros diversos campos. Por exemplo, como a relação da religião com a política, economia e mídia. Todo campo tem uma elite que detém a maior parte do poder. $O$ poder é expresso na quantidade de capital específico daquele campo que a pessoa ou grupo possui. A disputa social ocorreria na luta pela disputa do monopólio de produção do capital do campo. Dessa forma, os estabelecidos representam a elite, o grupo que possui o devido capital simbólico que faz com que prevaleça seu discurso. Do outro lado se tem os outsiders, que são os marginalizados, que não possuem acesso a tal capital.

A teoria de campo de Bourdieu, possibilita uma série de recortes, de tal forma que pode-se ter um campo dentro de um outro campo, tendo-se sub-campos com grupos que eram marginalizados no campo maior agindo como estabelecidos, como o núcleo daquele subcampo específico. Esse é o caso das religiões afro-brasileiras. As religiões afro-brasileiras 
passaram por um processo histórico de marginalização e estigmatização dentro do cenário do campo religioso brasileiro. Com a perseguição no Brasil colonial e ainda hoje sofrendo com a "guerra santa" imposta pelos neopentecostais (Silva, 2015). As religiões afro-brasileiras também são a principal forma de expressão cultural de negros na sociedade brasileira, sendo perseguida e estigmatizada de tal forma devido o racismo (Silva Jr., Hédio, apud Silva, 2015). Como foi apresentado, a idéia de estabelecidos-outsiders expressa a auto-imagem positiva de um grupo, que acredita possuir um carisma específico em oposição aos outros, fazendo-se prevalecer desse carisma através da estigmatização do outro. Essa relação ocorre justamente com o sentimento racial que esta presente nas religiões afro-brasileiras.

Dessa forma, pode-se pensar nas religiões afro-brasileiras como outsiders ao identificá-las como objeto de estigma negativo no campo religioso brasileiro. As associações com "culto ao diabo", a atitude ofensiva expressa no dito popular "chuta que é macumba", o baixo número de adeptos no censo, são exemplos dessa posição outsider. Por outro lado, as religiões afro-brasileiras expressão a luta do povo negro ao buscar resistir culturalmente através da manutenção dos laços de solidariedade. A unidade de negros em torno da religião possibilita a criação de um campo específico no qual o negro possui o poder simbólico. O negro pai-de-santo se torna o estabelecido, é ele quem possui o conhecimento, o axé. Sendo assim, a religião pode ser vista como um núcleo de resistência cultural, onde o outsider pode ascender simbolicamente. A coesão que o grupo religioso vivência possibilita a criação de uma auto-imagem positiva, criando um grupo de estabelecidos.

\section{O antropólogo e sua magia}

Tendo em mente esse debate em torno do pesquisador insider-outsider e da relação de poder entre estabelecidos-outsiders, irei analisar o livro "O antropólogo e sua magia" de Vagner Gonçalves da Silva (2015). O livro apresenta a tese de doutorado de Vagner Silva, em que ele analisa a prática da pesquisa etnográfica de antropólogos que estudam religiões afrobrasileiras. $\mathrm{O}$ autor entrevista diversos pesquisadores assim como líderes religiosos que tiveram seus terreiros pesquisados e analisa as implicações da relação entre pesquisador e objeto e as conseqüências das publicações de estudos nas comunidades religiosas. Apesar do livro de Vagner Gonçalves tratar especificamente de narrativas de antropólogos que estudam as religiões afro-brasileiras, essa análise desse campo específico possibilita uma compreensão maior de toda a prática do pesquisador que estuda alguma religião e se relaciona através do trabalho de campo com o grupo estudado. 
O livro de Vagner Silva possibilita trazer o debate insider-outsider e estabelecidosoutsiders para o campo prático da pesquisa religiosa no cenário afro-brasileiro. As religiões afro-brasileiras são religiões iniciáticas com uma tradição de transmissão oral dos conhecimentos. Os primeiros pesquisadores que estudaram o tema (Nina Rodrigues, Bastide, Verger) eram outsiders. Esses pesquisadores viram a necessidade de passarem pelos ritos de iniciação para conseguirem realizar suas pesquisas. Esse processo de constituição do campo de pesquisa das religiões afro-brasileiras aponta a necessidade de se tornar um insider para conseguir poder pesquisar as religiões iniciáticas. Tais autores, ao desfrutarem dos títulos religiosos recém adquiridos (em sua maioria de ogãns) e de seus títulos acadêmicos, como estabelecidos instituíram uma tradição narrativa acadêmica que moldou o cenário dessas religiões, servindo de modelo e referência para os grupos por eles estudados. Percebe-se, de uma forma geral, a presença de uma relação de poder íntima, no qual o pesquisador (outsider) se utiliza de seu prestígio acadêmico como forma de inserção no universo religioso. Uma vez estabelecido nesse universo, ele pode utilizar seu prestígio recém adquirido, ocupando um lugar de liminaridade, entre o universo acadêmico e religioso.

A vivência do trabalho de campo aponta para a dificuldade inicial do pesquisador em conseguir se relacionar com maior ou menor domínio com o universo que ele pesquisa. Essa dificuldade aponta para o insiderismo relativo, exigindo-se uma imersão e domínio mínimo daquele universo para poder compreendê-lo. Segundo Vagner, a visão de que no trabalho de campo o pesquisador consegue se manter numa distância que permite uma neutralidade, é impossível na prática. Dificilmente o pesquisador que pesquisa as religiões afro-brasileiras vai se manter indiferente as disputas e conflitos que permeiam esse universo. Outra dificuldade vivenciada pelo pesquisador é como se relacionar com a autoridade dos líderes religiosos. Nas religiões afro-brasileiras a fala do líder da casa tem autoridade máxima. A importância da oralidade aponta pra necessidade da maleabilidade do discurso. Dessa forma os líderes religiosos se utilizam de diversos recursos na produção de seus discursos nas entrevistas, assim como não aceitam que os pesquisadores valorizem opiniões de outros iniciados. Isso fica claro na fala do pesquisador entrevistado por Vagner.

"VAGNER: Ele [pai-de-santo] nunca te recriminou por causa das entrevistas? ISMAEL GIROTO: Uma vez, eu acho que está até relatado aí no trabalho [Giroto, 1990: 52], ele pega o microfone e diz que todas as informações da casa são com ele; quem sabe era ele; ele podia responder as perguntas. Eu senti isso como uma indireta pra mim: "Não pergunte muito ao pessoal, pergunte para mim"." (Silva, 2015, p. 40) 
A especificidade da linguagem do universo religioso afro-brasileiro, faz com que o pesquisador, ao adentrar nesse universo, seja classificado de acordo com essa linguagem. Isso faz com que o "grupo também mobiliz[e] seu sistema de classificação para tornar aquele que inicialmente era um "estrangeiro" em uma "pessoa de dentro"” (Silva, 2015, p. 88). Esse processo ocorre com a aproximação do pesquisador com o grupo. Um dos marcadores seria a descoberta do orixá do pesquisador pelos adeptos. Uma das pesquisadoras entrevistadas por Vagner afirma:

\begin{abstract}
"RITA AMARAL: Como o candomblé trabalha com o universo do arquétipo, eu estava sempre associada ao Obaluaiê que era uma figura bem vinda, ou por medo, ou por qualquer coisa [...[. Eles conversavam comigo, me contavam as coisas, mas me tratavam de uma maneira toda reverente que dava até um certo mal-estar. Quando a Sylvia jogou e viu que eu era de Ogum, ela falou: "Olha só, ela é de Ogum!" . E aí descambou a virar uma coisa mais light, mais amiga, mais tranqüila. Parece que eu adquiri mais confiabilidade. Porque ser de Obaluaiê era uma coisa meio de gente perigosa [...]. é uma coisa que passa por um universo místico também. Por conta desta confiabilidade que eu adquiri sem fazer nada, eu peguei muitas informações.” (Silva, 2015, p. 90)
\end{abstract}

Compreender essa língua do povo de santo é requisito básico para o pesquisador que se introduz nesse universo. Quem não conhece a língua de santo é considerado "cossi”" ou "aricô" pelos adeptos, marcando sua posição de outsider (Silva, 2015, p. 48). Apesar das religiões afro-brasileiras apresentarem uma certa timidez com a construção de discursos, participar de uma entrevista é visto como uma forma de valorização e reconhecimento de prestígio. Quanto mais prestigiado for o pesquisador (doutores e pesquisadores estrangeiros, por exemplo), mais prestigiado vai se sentir o entrevistado. Há um jogo de representações do qual o pesquisador se apropria para seu benefício.

\title{
A importância da iniciação
}

O trabalho de campo exige que o pesquisador se submeta a determinados rituais. Ao participar desses rituais, o pesquisador se vê na obrigação de respeitar certos preceitos. No caso das religiões afro-brasileiras, os pais-de-santo costumam estimular a participação dos pesquisadores nas atividades dos terreiros. No candomblé existe uma distinção entre os adeptos que possuem potencial para o transe religioso, que devem ser iniciadas na condição de $i a \hat{o}$, e os que não o possuem, que devem ser iniciadas no forma de ogãs. Os ogãs possuem maior prestígio dentro da visão desse grupo. Segundo Vagner: 
“Os terreiros procuram entrosar em seus postos de ogãs, além das pessoas provenientes do próprio meio religioso, os intelectuais e representantes das classes mais privilegiadas que, de algum modo, possam fornecer proteção, prestígio e apoio financeiro às atividades da casa." (Silva, 2015, p. 93)

A iniciação do pesquisador marca um esforço no sentido de se tornar um nativo. Esse processo marcou os principais pesquisadores das religiões afro-brasileiras. Segundo Vagner Silva:

\footnotetext{
"Nas pesquisas anteriores aos anos 40, a iniciação do antropólogo era justificada principalmente em termos das necessidades "técnicas" da pesquisa de campo, ficando o autor relativamente preservado re refletir sobre os significados de sua conversão e participação no culto.” (Silva, 2015, p. 95)
}

A conversão serve como um mecanismo que legitima a fala do pesquisador, no sentido de confirmar sua autoridade como alguém que "esteve lá". Como alguém "de dentro". Vagner Silva salienta que a conversão e iniciação do pesquisar não necessariamente acompanham uma absorção da fé religiosa. Pelo contrário, muitos pesquisadores convivem com a ambigüidade dos aspectos subjetivos, numa espécie de agnosticismo. Porém, o contato íntimo com as emoções religiosas leva a dilemas e debates internos que podem suscitar numa verdadeira conversão do pesquisador, como o que foi apontado pelo pesquisador entrevistado por Vagner.

\begin{abstract}
"ROBERTO MOTTA: Eu tive um problema ético e religioso. O problema ético era que eu não acredito e nunca acreditei na existência dos orixás. Então, eu sempre perguntava: "É lícito eu participar dos rituais dos orixás?" Depois tinha a minha formação católica, mas apesar destes escrúpulos todos eu passei adiante e a observação direta se transformou numa observação participante.

VAGNER: Mas você não pensava na obrigação em termos de uma estratégia de pesquisa?

ROBERTO MOTTA: Neste momento, sim. Eu pensava que aquilo tinha uma vantagem para a pesquisa. Mas, você imagina, que da terceira obrigação nem nota eu tenho. Tronou-se muito mais do que uma estratégia de pesquisa. Realmente, isso acontece com muitos pesquisadores. Eu me converti. Querendo ou não, me converti. E não me converti só junguianamente, arquétipos, sonhos - eu sonhava muito com os orixás. Xangô me apareceu em sonhos. Aparecia Iemanjá. Mandavam mensagens. Foi uma verdadeira conversão. Agora, não foi uma conversão intelectual, mas uma conversão psicológica [...]. Uma vez, numa obrigação de Balé que Manuel [pai-desanto] não me deixou olhar, eu abri a porta e tirei um retrato. E quatro meses depois eu tive um diagnóstico de um problema na vista tão sério que eu fiquei achando que era castigo. Até hoje eu acho que foi castigo." (Silva, 2015, p. 103 - 104)
\end{abstract}

Segundo Vagner da Silva, os pesquisadores que se iniciam nos terreiros, se filiam a religião mais na forma de um estilo de vida do que como uma referência afetiva propriamente religiosa. A iniciação, mesmo não sendo vista, predominantemente, como condição necessária 
para a pesquisa, acaba sendo uma conseqüência. Ao mesmo tempo que a iniciação traz benefícios para o pesquisador, também pode trazer certas complicações. Como por exemplo, o fato do pesquisador ter que sair da posição de observador para tomar frente em certos rituais. Assim como o fato de que, ao se iniciar, o pesquisador passa a pertencer àquela comunidade religiosa, tendo que seguir as etiquetas e procedimentos esperados de sua posição hierárquica. Ao pertencer a um terreiro, o pesquisador pode ver suas incursões em outras casas de santo negadas. O pesquisador adepto também pode ser visto como um concorrente no cenário religioso, levando a uma postura defensiva por parte dos pais-de-santo.

A iniciação também é vista com ressalvas pelo meio acadêmico, especialmente se envolver o transe religioso. Vagner Silva cita alguns pesquisadores que criticam a iniciação, como René Ribeiro (1952) e Jean Ziégler (1972). Para René, seria melhor para a pesquisa se o pesquisador não se submete-se a autoridade religiosa dos pai-de-santo. E Jean Ziégler afirmava que a introspecção dos pesquisadores que se iniciaram poderia ultrapassar as fronteiras da investigação científica racional.

\section{$O$ valor do texto escrito}

Outra questão importante na construção da narrativa escrita é a relação de valor estabelecida sobre a tradição oral dentro das religiões afro-brasileiras. Sobre isso, Vagner afirma:

\footnotetext{
"Na "lógica" das religiões afro-brasileiras, a palavra falada é considerada uma importante fonte de axé (força vital) e veículo do poder sagrado. Falar é um ato mágico que impregna por contaminação simbólica o sujeito da fala e seu ouvinte. $\mathrm{Na}$ transmissão do conhecimento litúrgico, o que dizer, quando, como e para quem são instanciais determinadas pela hierarquia religiosa. A entrevista etnográfica, por envolver a transmissão de conhecimentos, também é apreendida pelo grupo a partir desse contexto simbólico. Para o pai-de-santo, dar entrevistas ou falar ao antropólogo adquirem significados que vão além da simples transmissão de conhecimentos "objetivos", significando, muitas vezes, uma inversão dos procedimentos religiosos. Porque, nessas religiões, o processo de obtenção de conhecimento raramente se faz através de uma dinâmica de perguntas e respostas. Perguntar é uma quebra da regra do silêncio e do respeito, pois acredita-se que o conhecimento deva ser transmitido de acordo com os méritos de cada um e em função do tempo de iniciação." (Silva, 2015 p. 44)
}

Um aspecto importante dos estudos publicados é o impacto deles nas comunidades. No caso das religiões afro-brasileiras, Vagner demonstra que esses estudos têm moldado o campo, chegando a debater a possibilidade dos estudos criarem tradições religiosas. Segundo 
o autor: "As comunidades religiosas afro-brasileiras sempre demonstraram interesse pelos textos etnográficos que as descrevem." (Silva, 2015, p. 145)

\begin{abstract}
"As etnografias acadêmicas possibilitam, por exemplo, sistematizar o conhecimento religioso, tornando-o uma influente forma de transmissão "letrada" das tradições de uma geração a outra (uma via "complementar" ao modelo iniciático e hierático de aprendizado religioso), além de serem uma "tradução erudita" da religião - ainda muito discriminada - para circuitos sociais mais abrangentes.” (Silva, 2015, p. 146)
\end{abstract}

Por se tratarem de tradições orais, os textos etnográficos se constituíram como material de referência para os adeptos. O pesquisador ao falar sobre determinada tradição a acaba legitimando. Por outro lado, essas representações dos grupos apresentadas pelos pesquisadores acabam servindo como molduras que passam a serem seguidas. Tendo isso em mente, para as lideranças religiosas se tornou estratégico estar próximo dos autores dos textos etnográficos.

\title{
O lugar do pesquisador no estudo das religiões afro-brasileiras
}

O livro "O antropólogo e sua magia" de Vagner G. da Silva, demonstra que as etnografias são o resultado das observações do trabalho de campo e as alianças estabelecidas entre pesquisadores e o grupo pesquisado. Segundo Vagner, o antropólogo se encontra num estado de liminaridade entre o religioso e o leigo, se tornando um quase religioso (Silva, 2015, p. 61). Pode-se interpretar que hora ele é visto predominantemente como alguém de fora e hora como alguém de dentro.

Percebe-se, através das narrativas dos pesquisadores entrevistados por Vagner, a existência de um "establishment acadêmico", representado pelos pesquisadores conceituados e suas redes de relações. Existem antagonismos entre os pesquisadores, sendo que novos pesquisadores acabam tendo dificuldades para se inserirem nessas redes. Esses pesquisadores acabam tendo um domínio sobre o discurso acadêmico e público desses grupos religiosos. Visto sobre esse ângulo, os adeptos das religiões afro-brasileiras, se encontram como outsiders desse discurso acadêmico/científico. Porém, os grupos religiosos e seus adeptos, funcionam como um "establishment religioso" que detém o monopólio do discurso no universo dos terreiros. Nesse caso, o pesquisador, muitas vezes, que é o outsider, e é justamente seu prestígio como membro do universo científico, que ele utiliza para se inserir nesses grupos. Uma vez estabelecido no universo religioso, o pesquisador utiliza de seu 
capital simbólico, recém adquirido na religião, para legitimar seu o trabalho acadêmico produzido.

A pesquisa etnográfica e a observação participante são um esforço na superação do insiderismo relativo. A necessidade de iniciação no processo de pesquisa que diversos antropólogos vivenciaram se relaciona com a problemática do insiderismo absoluto em sua versão sociológica. Por ser uma religião iniciática e de tradição oral, o conhecimento é transmitido através das relações estabelecidas ao longo dos rituais As religiões afrobrasileiras, inicialmente, se encontravam fechadas de tal forma que a iniciação se tornava um recurso metodológico necessário. Hoje os pesquisadores já encontram uma maior abertura. Porém, mesmo assim, a iniciação é um recurso que os pais-de-santo utilizam para ter um "domínio" sobre os pesquisadores. Ao se iniciar numa casa, o pesquisador se vê obrigado a seguir os preceitos hierárquicos do grupo, passa a ter que seguir as "obrigações da casa", e isso nem sempre é vantajoso para o pesquisador. A iniciação também fortalece e estabelece laços entre o pesquisador e os adeptos.

A problemática do insiderismo absoluto em sua versão religiosa se apresenta de tal forma na pesquisa das religiões afro-brasileiras que o pesquisador se vê, por vezes, como um teólogo. A vivência com esse universo religioso dificilmente não modifica o pesquisador, levando-o, por vezes, a suspender e duvidar de seu senso crítico científico. Exige-se desses pesquisadores a capacidade de lidar e transitar entre os dois universos, atuando como intérprete. Há continuidades e similaridades entre esses dois universos, permitindo que o pesquisador crie identidades (profissional e religiosa) que não, necessariamente, sejam opostas. Em alguns momentos, acontece de perde-se a fronteira que separa o acadêmico do religioso. Tal como na narrativa de Bastide, que ao analisar um ritual se viu de tal forma impressionado que ele pede aos seus leitores que creiam no "fantástico" que ele presencia.

\footnotetext{
"Na sala tudo foi preparado... o babasalã,, isto é, aquele que chama e manipula os egum, tem na mão um bastão, o incha, e o coloca entre o lugar da assistência e o lugar dos egum, para que estes não possam abandonar o local que lhes é privado. Então o Espírito aparece... e a aparição canta. Creiam-me. Não se trata de um homem fantasiado. Escutei-lhe a voz" (Bastide, 1978: 142, grifo de Silva, apud Silva, 2015, p. 128)
}

Apesar do poder simbólico dos pais-de-santo como establishment em seu universo religioso, o antropólogo vivencia uma posição privilegiada por possuir a legitimidade "científica". O pai-de-santo se vê numa condição de troca com o pesquisador, no qual há um certo prestígio ou gratificação por se ter seu terreiro estudado. A diferença da tradição oral das 
religiões afro-brasileiras pra linguagem escrita acadêmica, faz com que um dos principais mecanismos de poder dos pais-de-santo, seja o prolongamento na construção de seu discurso com o pesquisador, se recorrendo aos ritos, mitos e iniciação. O pai-de-santo sabe que não deve "entregar o ouro" de vez. O antropólogo, por sua vez, se aproveita dessa relação. Esse fenômeno é bem exemplificado na fala de Medeiros (1994):

\begin{abstract}
"E por que os sacerdotes aceitam a pesquisa? Acho que ninguém sabe, mas hoje é chique para uma casa de orixá ter um "ólogo" de plantão. Chiquíssimo" Esse é meu antropólogo". "Ah é, eu tenho um musicólogo"; "Eu tenho um etnólogo"; "Eu tenho um sociólogo". Chiquíssimos!. Quanto mais chique o pai-de-santo, de mais "ólogos"ele se rodeia. E os "ológos" usam isso, vocês pensam que não? Usam. "Olha, vamos levar pai fulana em tal lugar que ele ainda não conhece”. E lá vai pai fulana à reboque do "ólogo". Aí é causa e feito. Acho que a sedução existe dos dois lados. O sacerdote cai de pau em feitiçaria para amarrar o "ólogo" e o "ólogo" aceita tudo para entrar na profundidade daquilo que ele quer aprender (Medeiros, 1994: 25 apud Silva, 2015, p. 106)
\end{abstract}

O antropólogo vivencia uma posição liminar entre o acadêmico e o religioso. Essa condição tem seu prestígio específico. O pesquisador, ao possuir a legitimidade sobre as narrativas na forma escrita, num universo religioso oral, acaba tendo um papel importante na formação de tradições. O domínio da escrita por parte do antropólogo cria narrativas religiosas e molda o universo religioso pesquisado. Quando o pesquisador possui algum título de iniciação religiosa, soma-se ao prestígio acadêmico o prestígio simbólico religioso. Há uma relação de poder entre pesquisador e pesquisado, no qual a balança tende ao pesquisador. Sobre isso afirma Silva:

\footnotetext{
"A escrita, nas sociedades que a utilizam, é vista, em relação à tradição oral, como expressão de uma cultura "superior" (erudita). No trabalho de campo essa percepção, ainda que se faça sob contextos diferenciados, também se verifica como resultado da relação de hierarquia e poder existente entre o grupo do observador (sujeito da escrita) e o do observado (objeto da escrita)." (Silva, 2015, p. 65)
}

Fica claro, dessa forma, o poder que detêm as narrativas escritas pelos pesquisadores nesse campo religioso. Os pais-de-santo têm buscado escrever livros como forma de consolidar sua narrativa pessoal. A influência dos livros etnográficos e da escrita acadêmica é tanta sobre as religiões afro-brasileiras que os livros escritos pelos pais-de-santo acabam seguindo uma estrutura semelhante. Diferente dos livros umbandistas, onde prevalece uma influência da literatura kardecista, os livros escritos por líderes dos candomblés possuem uma linguagem menos narrativa e mais descritiva. Tais livros raramente são apresentados como resultado de manifestações divinas ou de contato espiritual. Segundo Vagner, essa valorização 
da escrita etnográfica acaba prejudicando a própria característica do discurso dessas religiões. São poucos os trabalhos publicados por adeptos que optem por uma linguagem que se aproxime mais desse universo religioso. Devido esses fatores, o trabalho do pesquisador nesse campo chega a ser confundido com uma espécie de teologia, sendo os próprios pesquisadores identificados como profetas.

\footnotetext{
“JOSÉ BARBOSA Eu acho que há um merecimento grande para o candomblé em si, para que ele possa ser melhor entendido, porque tem muita gente que ataca a nossa religião por falta de entendimento, Então, esse trabalho dos pesquisadores é fantástico. Eu até acho que eles são enviados dos deuses, dos orixás. Como o candomblé pode esclarecer a sua religião se não através do trabalho deles? [...] Às vezes falha, mas tem coisas muito mais positivas do que negativas.” (Silva, 2015, p. 168)

"SERGIO FERRETTI Eu não digo que eu faço teologia. Eu não sou teólogo. Mas é muito próximo da teologia o trabalho que a gente faz, a antropologia da religião. Eu lamento não ser teólogo. Se eu fosse teólogo de formação, eu acho que faria um trabalho teológico mais bem feito." (Silva, 2015, p. 168)
}

Isso demonstra essa tensão entre a prática do discurso científico e religioso, fazendo com que as narrativas etnográficas, além de sua contribuição acadêmica acabem tendo uma função proselitista. Essa dimensão sagrada do texto é percebida não só pelos adeptos, mas também pelos pesquisadores. Segundo Vagner, não raro os pesquisadores utilizam de despachos, trabalhos e ascendem velas para verem seu texto publicado e a aprovação de bolsas e projetos de pesquisa. Confundem-se, dessa forma, as fronteiras entre o universo acadêmico e a religião. Isso fica claro no relato apresentado pelo próprio Vagner em seu livro:

\begin{abstract}
"Nessas circunstâncias, o livro deixa de ser apenas um "suporte de informações" e passa a ser um objeto impregnado de magia por conter parte do axé que ele pretende representar. Em 1990, assisti, em São Luís, ao lançamento do livro Boboromina [...]. O evento ocorreu no terreiro Casa de Nagô, onde os livros foram expostos numa mesa no centro do principal espaço público do terreiro. Num determinado momento os voduns incorporaram em algumas adeptas da casa que, fazendo um círculo ao redor da mesa, dançaram e reverenciaram aquela obra de "interpretação sociocultural" da religião. (Silva, 2015, p. 170)
\end{abstract}

\title{
Considerações Finais
}

Vagner Gonçalves da Silva, ao falar em seu livro sobre sua experiência com a pesquisa de campo, lembra que, antes de iniciar a pesquisa ele era adepto iniciado no candomblé, tendo passado por um ritual de bori. Porém, ele se afastou dessa religião, e somente depois, na condição de ex-adepto que iniciou seu trabalho de campo no mestrado. Segundo o autor, em seu trabalho de campo ele teve o benefício de conseguir se relacionar e 
transitar com maior facilidade naquele universo, por outro lado, ele teve a dificuldade de ter que fazer o exercício de distanciamento para conseguir entrar alguns aspectos já tidos como naturais.

Através do livro de Vagner percebem-se as dificuldades que o pesquisador enfrenta no trabalho de campo. Deve-se destacar a especificidade do tipo de vivência de quem estuda as religiões afro-brasileiras. Por serem religiões iniciáticas, o pesquisador enfrenta uma certa dificuldade, recorrendo, muitas vezes, a iniciação. O estigma forte das religiões afrobrasileiras, assim como a ausência de uma tradição escrita, faz com que o discurso do pesquisador tenha bastante poder. As narrativas escritas pelos pesquisadores, podem se tornar um referencial, um modelo para os adeptos. Quando a titulação acadêmica soma-se ao prestígio de uma posição ritualística (como a de ogã), o pesquisador se vê numa condição privilegiada de liminaridade, entre o discurso acadêmico e religioso, onde, por vezes, o discurso científico se confunde com o teológico.

Dessa forma, percebe-se que é difícil estabelecer essas fronteiras entre insider e outsider. Porém, se faz presente a problemática, no próprio dilema apresentado pelos pesquisadores. O estudo do fenômeno religioso, por vezes, coloca o pesquisador numa condição que o desafia racionalmente, tal como aconteceu com Bastide no rito do egum e com os sonhos de Roberto Motta. Enquanto Bastide pede aos seus leitores que façam como ele e creiam, Motta expressa o conflito sobre a crença. Motta fala que teve um dilema moral porque ele não acredita e nunca acreditou em orixás, porém ele, mesmo assim, sem acreditar em orixás, sonha com eles e acredita que teve um problema de visão como castigo por não respeitar um preceito. Motta mostra que, mesmo não acreditando, acabou se tornando um adepto.

Deve-se colocar em questão se o mesmo ocorre com quem estuda outras religiões. As religiões afro-brasileiras, devido sua exclusividade de linguagem, exigem do pesquisador que ele se insira de alguma forma naquele universo. Mesmo que não ocorra a iniciação direta e conversão, o pesquisador se vê, de alguma forma, constrangido pela ritualística, tendo que se submeter à estrutura hierárquica religiosa e ao poder do pai-de-santo. Nesse sentido, o pesquisador é um outsider que busca se aproximar do establishment religioso. Se, por um lado, para o antropólogo se iniciar é uma estratégia que permite uma participação nas esferas de poder e conhecimento do terreiro, a não aceitação de uma indicação pode ser uma verdadeira ofensa, tal como narra a pesquisadora entrevistada por Vagner. 
"RITA AMARAL: O primeiro dia que eu cheguei lá [no terreiro], ele [Ogum] já me suspendeu. Pior que eu não sabia o que fazer, quando o Ogum perguntou se eu queria; eu disse que sim. Você não domina a regra, mas sabe que certas coisas não se fazem. Como dizer não para um orixá, para um deus que acabou de te escolher, mesmo nunca tendo te visto na vida? [...] Tanto que eu argumentei com o Ogum que eu não podia fazer nada. "Eu não posso fazer nada pelo senhor". "Mas eu quero o seu coração", ele falou pra mim. "Você tem coração bom". Se um orixá te suspende em nome do seu coração, você vai fazer o quê? Não tem o que fazer." (Silva, 2015, p. 95)

O debate insider-outsider não pode se encerrar numa conclusão puramente filosófica, uma vez que ele implica numa série de problemas práticos da pesquisa de quem estuda uma comunidade religiosa. Percebe-se, através das narrativas presentes no livro de Vagner, que o discurso religioso das religiões afro-brasileiras apresenta uma especificidade própria de uma religião ancestral de tradição oral. A narrativa escrita pelo pesquisador não consegue alcançar a riqueza e complexidade desse discurso religioso, devido à necessidade da formatação acadêmica. A riqueza da experiência religiosa que o pesquisador acaba vivenciando em seu trabalho de campo o coloca numa posição que ele mesmo questiona sua própria razão. Não seria absurdo, dessa forma, pensar que a narrativa e a experiência religiosa possa ter um elemento sui generis, que vai além da razão prática, e do discurso lógico. Ficando, dessa forma, o desafio ao pesquisador de traduzir esse universo para uma linguagem mais inteligível, a da escrita.

\section{Referências}

BOURDIEU, Pierre. A Economia das Trocas Simbólicas. Perspectiva. 2005.

A Distinção: crítica social do julgamento. Zouk. 2011.

ELIAS, Norbert; SCOTSON, John L.. Os estabelecidos e os outsiders: sociologia das relações de poder a partir de uma pequena comunidade. Rio de Janeiro: Zahar, 2000.

ENGLER, Steven; GARDINER, Marq. A filosofia semântica e o problema insider/outsider.

Rever. Revista de Estudos da Religião. setembro. 2010. p. 89 - 105.

SILVA, Vagner Gonçalves. O antropólogo e sua magia: Trabalho de campo e texto etnográfico nas pesquisas antropológicas sobre religiões afro-brasileiras. São Paulo: Editora da Universidade de São Paulo (EDUSP), 2015.

et al. Intolerância Religiosa: impactos do neopentecostalismo no campo religioso afro-brasileiro. São Paulo: Editora da Universidade de São Paulo, 2015.

TURNER, Victor. O processo ritual: estrutura e antiestrutura. Petrópoles (RJ): Vozes. 2013. 